\title{
El despensero mayor de las raciones de la Casa del rey. \\ Estudio institucional y documentos de un oficio curial en la Castilla Trastámara (1380-1456)*
}

\author{
The despensero mayor de las raciones \\ of the Royal Household. \\ Institucional study and documents of a curial office \\ in the Castile of Trastámaras \\ (1380-1456)
}

\author{
Francisco de Paula CAÑAS GÁLVEZ \\ Profesor de Historia Medieval \\ Universidad Complutense de Madrid \\ franccan@ghis.ucm.es
}

Recibido: 6 de marzo de 2015

Aceptado: 13 de abril de 2015

\section{RESUMEN}

En este trabajo se estudia uno de los principales oficios áulicos surgidos al amparo de las reformas institucionales y burocrático-administrativas auspiciadas por los primeros monarcas de la Casa de Trastámara en Castilla: el despensero mayor de las raciones de la Casa del rey. Sustentado sobre una amplia documentación de archivo, la mayor parte de ella hasta ahora inédita, esta investigación reconstruye los parámetros legales y operativos dentro de los cuales el nuevo cargo se desarrolló entre los años finales del siglo XIV y los centrales del siglo XV, periodo, este último, en el que alcanzó su madurez institucional de la mano de Juan García de Soria y su hijo, Luis García de Morales, oficiales ambos a los que se les dedican varias páginas que abundan en sus trayectorias cortesanas.

PALABRAS CLAVE: Casa Real de Castilla, Juan I, Enrique III y Juan II de Castilla, escribanos reales; despenseros reales.

\section{ABSTRACT}

This paper examines one of the leading courtiers trades arising under the administrative bureaucratic and institutional reforms sponsored by the first monarch of the House of Trastámara in Castile: the grea-

\footnotetext{
* Este trabajo se ha realizado en el marco del proyecto de investigación financiado por la Secretaria de Estado de Investigación, Desarrollo e Innovación: "Prácticas de comunicación y negociación en las relaciones de consenso y pacto en la cultura política castellana, ca. 1230-1504”. HAR2013-42211-P. Proyecto de I+D del Programa Estatal de Fomento de la Investigación Científica y Técnica de Excelencia. Subprograma de Generación de Conocimiento, 2015-2017.
} 
test steward ration of the royal household. Sustained by extensive documentation from archives, most of it hitherto unpublished, this research reconstructs the legal and operational parameters within which the new position developed from the final years of the fourteenth century through the central fifteenth century period, in which its institutional maturity is reached through the work of Juan García de Soria and his son, Luis García Morales, both officers whose courtesan paths are here described.

KEYWORDS: Royal castilian household, Juan I, Enrique III and Juan II of Castile, royal notaries, royal despensa.

\section{RÉSUMÉ}

Dans ce travail on étudie l'un des métiers principaux de la Cour, surgi sous la protection des réformes institutionnelles et bureaucratiques-administratives patronnées par les premiers monarques de la Maison de Trastámara en Castille : le Dépensier Majeur des Rations de la Maison du Roi. Soutenue sur une ample documentation de fichier, la plupart d'elle jusqu'à présent inédite, cette recherche reconstruit les paramètres légaux et opérationnels à l'intérieur desquels la nouvelle charge s'est développée entre les années finales du XIV siècle et les centrales du XVe siècle, période, dans lequel a atteint sa maturité institutionnelle de la main de Juan García de Soria et son fils, Luis García de Morales, employés tous les deux, auxquels on dédie quelques pages qui abondent dans leurs trajectoires courtoises.

MOTS CLÉ : Maison Royal de la Castille, Juan I, Enrique III et Juan II de la Castille, greffiers royaux, dépensiers royaux.

SUMARIO: 1. Introducción. 2. Despensa y despenseros reales en Castilla (siglos XII-XV). 3. Los despenseros mayores de las raciones de la Casa del Rey (1382-1456). 3.1. Competencias burocráticoadministrativas y marcos legales de actuación. derechos arancelarios. 3.2. Los titulares del oficio: perfiles biográficos y trayectorias áulicas. 3.2.1. Juan García de Soria (a. de 1397-†1446). 3.2.2. Luis García de Morales ( $i ?-\uparrow 1456)$. 4. Conclusión. 5. Apéndice documental.

\section{Introducción ${ }^{* *}$}

En las últimas dos décadas la historiografía ha puesto de manifiesto como hecho incuestionable que las reformas de carácter institucional y burocrático-administrativas impulsadas por los Trastámara tras su llegada al trono contribuyeron de manera palmaria a fortalecerles y consolidarles definitivamente en el plano político, tan convulso en aquellos años de transiciones de diversa índole y características ${ }^{1}$. Sin embargo, y más allá de

\footnotetext{
${ }^{* *}$ Las siglas y abreviaturas utilizadas en el presente trabajo han sido las siguientes: ACA: Archivo de la Corona de Aragón. AGN: Archivo General de Navarra. AGS: Archivo General de Simancas. AHN: Archivo Histórico Nacional. AHNNob: Archivo Histórico de la Nobleza. AM: Archivo Municipal. ASDRT: Archivo de Santo Domingo el Real de Toledo. BN: Biblioteca Nacional. CYSR: Casa y Sitios Reales. DC: Diversos de Castilla. EMR: Escribanía Mayor de Rentas. MYP: Mercedes y Privilegios. PR: Patronato Real. QC: Quitaciones de Corte. RAH: Real Academia de la Historia.

${ }^{1}$ En relación a los primeros Trastámaras en Castilla hasta Juan II véanse los trabajos de Francisco de Paula Cañas Gálvez, "Las casas de Isabel y Juana de Portugal, reinas de Castilla. Organización, dinámica institucional y prosopografía (1447-1496)", en Las relaciones discretas entre las monarquías hispana y portuguesa. Las casas de las reinas (siglos XV-XIX), Madrid, 2008, vol. 1, pp. 9-231; "La cámara de Juan II: vida privada, ceremonia y lujo en la corte de Castilla a mediados del siglo XV", en Evolución
} 
las grandes instituciones que después de 1369 se fueron asentando y consolidando de manera definitiva en el plano áulico castellano, principalmente la Audiencia ${ }^{2}$, cancillería $^{3}$, las contadurías ${ }^{4}$ y el Consejo Real ${ }^{5}$, la política reformista pergeñada por Alfonso

y estructura de la Casa Real de Castilla, Madrid, 2010, vol. 1, pp. 81-195; "La Casa de Juan I de Castilla: aspectos domésticos y ámbitos privados de la realeza castellana a finales del siglo XIV (ca. 1370-1390)" En la España Medieval, 34, 2011, pp. 133-180; Burocracia y cancillería en la corte de Juan II de Castilla (1406-1454). Estudio institucional y prosopográfico, Salamanca, 2012; "El canciller Juan Martínez del Castillo: perfil biográfico e institucional de un letrado de la realeza Trastámara (1369-1409)", En la España Medieval, 36, 2013, pp. 135-153; "Structure et organisation de la Maison du roi de Castille pendant la seconde moitié du XIV e siècle. Les majordomes et la Chambre royale de Jean Ier (1379-1390)", en, Les entourages princiers à la fin du Moyen Âge. Une approche quantitative, Alexandra Beauchamp (Dir.), Madrid, 2013, pp. 113-129; "Pacto y cultura de consenso en la Castilla de Juan II: La familia Romero, una dinastía de oficiales al servicio de la Corona (ca. 1407-ca. 1465)", Pacto y consenso en la cultura política peninsula. Siglos XI al XV, Madrid, 2014, pp. 319-339; "Una conspiración en la corte de Castilla: la trama burocrática-administrativa en la caída del condestable Álvaro de Luna", en La part de l'ombre. Artisans du pouvoir et arbitres des rapports sociaux. La place des intermédiaires dans la gestion des conflits (VIII-XV siécles), Limoges, 2014, pp. 267-287; "García Fernández de Alcalá: notas biográficas y contextos institucionales de un secretario y agente fiscal del rey de Castilla (1440-1467)", en Agentes en los sistemas fiscales en Andalucía y los reinos hispánicos (siglos VIII-XV): Un modelo comparativo, Mercedes Borrero Fernández, Juan Carrasco Pérez, Rafael. G. Peinado Santaella (editores), Madrid, 2014, pp. 67-83; y "Algunos apuntes sobre micer Salagrús Bocanegra, tesorero mayor de la guerra de moros y escribano de las armadas del rey. Logística económica y militar en la Frontera de Granada (1388- 1425$)$ " (en prensa). José Manuel Nieto Soria, Legislar y gobernar en la Corona de Castilla: El Ordenamiento Real de Medina del Campo de 1433, Madrid, 2000. Con una visión de conjunto de la Casa Real de Castilla en la Edad Media citar las obras de Benjamín González Alonso, Gobernación y gobernadores. Notas sobre la administración de Castilla en el periodo de formación del Estado moderno, Madrid, 1974; Rogelio Pérez Bustamante, El gobierno y la administración de la Corona de Castilla (1230-1474), Madrid, 1976, (2 vols.); David Torres Sanz, La administración central en Castilla durante la Baja Edad Media, Valladolid, 1982; Miguel Ángel Ladero Quesada, "La casa real en la Baja Edad Media", Historia, Instituciones, Documentos, 25, 1998, pp. 327-350; Jaime de Salazar y Acha, La casa del Rey de Castilla y León en la Edad Media, Madrid, 2000; y Pedro Andrés Porras Arboledas, Flocel Sabaté i Curull y Eloísa Ramírez Vaquero, La época medieval: administración y gobierno, Madrid, 2003.

${ }^{2}$ Sobre la administración de justicia y la Audiencia Real en el período bajomedieval son de referencia los estudios de Miguel Ángel Pérez de la Canal, "La justicia en la Corte de Castilla durante los siglos XIII al XV”, Historia, Instituciones, Documentos, 2, 1975, pp. 283-481; José Sanchez-Arcilla Bernal, La administración de justicia real en León y Castilla (1252-1504), Madrid, 1980; Carlos Garriga, La Audiencia y Chancillerías castellanas (1371-1525). Historia política, régimen jurídico y práctica institucional, Madrid, 1994; Luis Vicente Díaz Martín, Sobre los orígenes de la Audiencia Real, Sevilla, 1997; y Francisco de Paula Cañas Gálvez, Burocracia..., pp. 170-181.

${ }^{3}$ Lope Pascual Martínez, "La Cancillería de Enrique II de Castilla”, Miscelánea Medieval Murciana, I (1973), pp. 175-202; "Notas para un estudio de la cancillería mayor de Castilla. La cancillería de Juan I de Castilla", Miscelánea Medieval Murciana IV, 1978, pp. 175-240; "Notas de cancillería castellana. La cancillería real de Enrique III de Castilla, Miscelánea Medieval Murciana, VI, 1980, pp. 170-205; "La Cancillería real castellana durante la regencia del Infante de Antequera", Miscelánea Medieval Murciana, XI, 1984, pp. 177-236; también, y con abundante bibliografía actualizada Francisco de Paula Cañas Gálvez, Burocracia..., pp. 31-524.

${ }^{4}$ Acerca de las contadurías entre los años finales del siglo XIV y los centrales del XV contamos con los trabajos de Rafael Mendizábal Allende, "La contaduría mayor de cuentas", Revista de Derecho judicial 
$\mathrm{XI}^{6}$, continuada por Enrique II y culminada con éxito por sus herederos y sucesores Juan I, Enrique III y Juan II, dio lugar a la aparición de un buen número de oficios curiales de carácter menor que permitieron de manera significativa engranar y agilizar las necesidades de una monarquía cada más compleja y dinámica a la hora de gobernar más eficazmente y mejor a sus súbditos como manera de asentar sobre cimientos firmes los nuevos programas de la acción política de los Trastámara castellanos.

Entre la dilatada lista de estos oficios de nuevo cuño aparecidos o consolidados definitivamente entonces figuran los escribanos de cámara, secretarios, contadores, oidores, maestresalas, refrendarios o relatores cuyo papel fue esencial a la hora de atender y gestionar correctamente la labor burocrático-administrativa, económica, judicial, ceremonial, representativa y propagandística de la Corona ${ }^{7}$.

Entre ellos habría que incluir también el poco conocido oficio de despensero mayor de las raciones de la Casa del rey, objeto de este estudio, un cargo, como se-

(Madrid, enero-mayo 1966), p. 11-35; Miguel Ángel Ladero Quesada, La Hacienda Real de Castilla en el siglo XV, La Laguna, 1973, pp. 17-22; y Fiscalidad y poder real en Castilla (1252-1369), Madrid, 2011, pp. 227-229. Rogelio Pérez Bustamante, "Del sistema de Contadurías al Consejo de Hacienda 1433-1525 (Una perspectiva institucional)", Historia de la Hacienda Española, (épocas antigua y medieval), Madrid, 1982, p. 681-738. Entre los trabajos dedicados a algunos contadores en particular, citar las obras de Alfonso Franco Silva, "Alfonso Pérez de Vivero, Contador Mayor de Juan II de Castilla: un traidor y su fortuna", Hispania, vol. 47, n 165, 1987, pp. 83-116; Isabel Montes Romero-Camacho, "El judío sevillano don Yuçaf Pichón, contador mayor de Enrique II de Castilla (1369-1379)", Judaísmo hispano. Estudios en memoria de José Luis Lacave Riaño (Coord. Elena Romero Castelló), vol. 2, 2003, pp. 561-574; y "El converso sevillano Nicolás Martínez de Medina (o de Sevilla), contador mayor de Castilla. Apuntes para una biografía", Espacio, Tiempo, Forma. Serie III. Historia Medieval, 27, 2014, pp. 343-379; Francisco de Paula Cañas Gálvez, Burocracia..., pp. 124-168; y Alfonso de Ceballos-Escalera y Gila, "Generación y semblanza de Fernán López de Saldaña, Contador Mayor de Juan II de Castilla", Medievalismo, 21, 2011, p. 161-206.

${ }^{5}$ Salustiano de Dios, "Ordenanzas del Consejo Real de Castilla (1385-1490)", Historia, Instituciones, Documentos 7, 1981, pp. 5-81; El Consejo real de Castilla (1385-1522), Madrid, Centro de Estudios Constitucionales, 1982; y Francisco de Paula Cañas Gálvez, Burocracia ..., pp. 141-147.

${ }^{6}$ Para tiempos de Alfonso XI son de referencia en este sentido los artículos de Salvador de Moxó, "El auge de la burocracia castellana en la corte de Alfonso XI. El camarero Fernán Rodríguez Pecha y su hijo el tesorero Pedro Fernández Pecha", en Homenaje a Agustín Millares Carló, Las Palmas, Confederación española de Cajas de Ahorros, 1975, vol. II, pp. 11-42; y "La promoción política y social de los "letrados" en la corte de Alfonso XI", Hispania, vol. 35, n 129, 1975, pp. 5-30.

${ }^{7}$ Francisco de Paula Cañas Gálvez, Burocracia ..., pp. 71-202; y "La cámara de Juan II...”, pp. 81195. Desde la perspectiva puramente ceremonial y representativa del periodo Trastámara son de referencia los trabajos de José Manuel Nieto Soria, Fundamentos ideológicos del poder real en Castilla (siglos XIII-XVI), Madrid, 1988; "Apología y propaganda de la realeza en los cancioneros castellanos del siglo XV: Diseño literario de un modelo político", En la España Medieval, 11, 1988, pp. 185-222; Ceremonias de la realeza. Propaganda y legitimación en la Castilla Trastámara, [s.1.], 1993; "Propaganda política y poder real en la Castilla Trastámara": Una perspectiva de análisis", Anuario de Estudios Medievales, 25-2, 1995, pp. 489-516; "Ceremonia y pompa para una monarquía: Los Trastámara de Castilla", Cuadernos del Centro de Estudios Medievales y Renacentistas, 17, 2009, pp. 51-72; "El consenso como representación en la monarquía de la Castilla Trastámara: Contextos y prácticas", Edad Media: Revista de Historia, 11, 2010, pp. 37-62; "Los espacios de las ceremonias devocionales y litúr- 
guidamente tendremos ocasión de comprobar, especializado y técnico, cuyo nacimiento y desarrollo refleja de igual modo la creciente complejidad de la vida cortesana y el deseo y la necesidad de la monarquía por dotarse de oficios y oficiales capaces de garantizar el perfecto funcionamiento de las nuevas, y también antiguas, instituciones regias castellanas.

El objetivo, pues, del presente trabajo abundará en el estudio de este oficio. Tras una presentación en la que profundizaremos en la estructura y desarrollo de la despensa real de la corte castellana entre los siglos XII y XV, analizaremos las circunstancias y contextos político-institucionales que propiciaron que el nuevo oficio se segregara de la despensa a finales del siglo XIV creando una instancia burocráticoadministrativa propia y su posterior desarrollo en tiempos de Juan I y Enrique III, culminando durante el reinado de Juan II con figuras de la talla Juan García de Soria y su hijo Luis García de Morales, los dos oficiales que llevaron al nuevo oficio a su plenitud institucional. Se profundizará en ambos perfiles biográficos, verdaderos parámetros del oficial del aparato burocrático-administrativo de los Trastámara, haciendo un especial hincapié en las posibilidades que el ejercicio de este cargo, y otros que acumularon a lo largo de sus largas andaduras cortesanas hasta el fallecimiento de Luis en 1456, momento de pleno desarrollo institucional del mismo y en el que, al parecer, se abre un paréntesis institucional hasta tiempos de los Reyes Católicos cuando el oficio parece recuperar su protagonismo con Francisco Ramírez de Madrid y su hijo Ferrand, personajes, ambos, ya tratados adecuadamente por la historiografía ${ }^{8}$.

Se completa el estudio con la aportación de un amplio apéndice que recoge casi medio centenar documentos inéditos entre los que se incluyen albaláes, cédulas y nóminas, además de un memorial redactado a finales del siglo XV sobre la dinámica institucional de dicho oficio en tiempos de Juan II, que nos han servido de base crítica y soporte científico para profundizar en los objetivos propuestos.

\section{Despensa y despenseros reales en Castilla (siglos XII-XV)}

Aunque no conocemos ordenamientos jurídicos ni documento de creación alguno, todo hace pensar, como apuntábamos más arriba, que el oficio de despensero mayor

gicas de la monarquía Trastámara", Anales de Historia del Arte, Extra 2, 2013, pp. 243-258. Para la época de los Reyes Católicos citar las obras de Rafael Domínguez Casas, Arte y etiqueta de los Reyes Católicos. Artistas, residencias, jardines y bosques, Madrid, 1993, pp. 223-226; María del Carmen González Marrero, La Casa de Isabel la Católica. Espacios domésticos y vida cotidiana, Ávila, 2004; y Álvaro Fernández de Córdova Miralles, La corte de Isabel I. Ritos y ceremonias de una reina (1474-1504), Madrid, 2002.

${ }^{8}$ Sobre Francisco son de referencia las obras de Pedro Andrés Porras Arboledas, "El secretario real Francisco Ramírez de Madrid: Apuntes para una biografía", Espacio, Tiempo, Forma. Serie III. Historia Medieval, 8, 1995, pp. 169-182; y Francisco Ramírez de Madrid (144?-1501): primer madrileño al servicio de los Reyes Católicos, Madrid, 1996. También José Damián González Arce, “Trabajar para el príncipe. Los salarios de los servidores de la Casa del príncipe de Asturias y Gerona (Juan de Aragón y Castilla, 1478-1497)", Anuario de Estudios Medievales, 39/2, 2009, pp. 782 y 786. 
de las raciones de la Casa del rey nació con toda seguridad en el seno de las reformas burocrático-administrativas auspiciadas por Juan I, seguramente nada más llegar al trono de Castilla9.

Pero ¿en qué contextos burocrático-institucionales se dio esta circunstancia? Para comprender mejor la llegada a este punto y con la intención de contextualizar política e institucionalmente la aparición de nuestro oficio y su posterior esplendor a mediados del siglo $\mathrm{XV}$, conviene hacer un repaso sobre el origen, desarrollo y competencias del oficio matriz de despensero mayor en la corte de Castilla ${ }^{10}$.

No parece necesario insistir en que la despensa regia era de trascendental importancia para el correcto desarrollo de la vida cotidiana de los monarcas, ya que sus titulares tenían como una de sus principales responsabilidades el abastecimiento de los alimentos que se servían en la mesa del monarca ${ }^{11}$, incluso durante los viajes del rey y las campañas militares ${ }^{12}$.

Sus oficiales eran, pues, personas de gran relevancia en la corte. De “... gran ofiçio e provechoso..." lo calificaba Fernández de Oviedo ${ }^{13}$. En ello abundaban ya las Partidas cuando aseguraban que los despenseros eran “.... Oficiales que compran las cosas necesarias para el servicio del rey...."14. Sus titulares, según esta misma fuente, deberían ser “... diligentes, entendidos, leales y tener algunos bienes...."15, es decir, oficiales de la total confianza del rey. Por ello, Pedro IV de Aragón en sus conocidas Ordinacions aseguraba que este oficio debía recaer en ... algun hom bo e leyal quie sia nomenat museu, per Nós elegidor ${ }^{16}$.

Dada la cualificación de sus titulares y el nivel intelectual de alguno de estos despenseros ${ }^{17}$, el oficio pronto gozó de prestigio entre los grandes señores. El citado Don Juan Manuel aseguraba que tenía “...muy grant poder en casa del señor”18; por ello,

\footnotetext{
${ }^{9}$ Luis Suárez Fernández, Historia del reinado de Juan I de Castilla. Tomo I: Estudio, Madrid, 1977, pp. 311-390. Sobre este periodo de reformas institucionales y burocrático-administrativas véanse sus aspectos más generales en Francisco de Paula Cañas Gálvez, "El canciller...”, pp. 136-137, y "Pacto y cultura...", pp. 319-235.

${ }^{10}$ Jaime de Salazar y Acha, La casa ..., pp. 288-293.

${ }^{11}$ Jaime de Salazar y Acha, La casa ..., p. 288.

${ }^{12}$ Francisco de Paula Cañas Gálvez, Itinerario de Alfonso XI de Castilla. Espacio, poder y corte (13251350), Madrid, 2014, p. 24

${ }^{13}$ Gonzalo Fernández de Oviedo, Libro de la cámara real del príncipe don Juan (Edición de Santiago Fabregat Barrios), Valencia, 2006, p. 127.

${ }^{14}$ En ello también insiste Don Juan Manuel. Don Juan Manuel, Libro de los estados (Edición de i. r. Macpherson y R. Brian Tate, Madrid, 1991, pp. 289-291.

${ }^{15}$ Partidas II, 9, 13.

${ }^{16}$ Ordinaçions de la Casa y Cort de Pere el Cerimoniós (Edició a cura de Francisco M. Gimeno, Daniel Gonzalbo y Josep Trenchs, estudi introductori de Francisco M. Gimeno Blay), Valencia, 2009, p. 72.

${ }^{17}$ Este podría ser el caso de Juan Rodríguez de Cuenca, despensero mayor de la reina Leonor de Aragón y autor de la conocida Suma de Reyes. J. Rodríguez de de Cuenca, Suma de reyes du despensero (Édition et présentation de Jean-Pierre Jardin), París, 2013.

${ }^{18}$ Don Juan Manuel, Libro de los estados..., pp. 289-290.
} 
estos oficiales, afirmaba Alfonso X, debían ser “... dilijentes, entendidos, leales y tener algunos bienes..."19, cualidades que puntualizaba aún más Don Juan Manuel en su Libro de los Estados cuando afirmaba que además tenían que ser personas de “... buen entendimiento et leal et de buen alma, et que quiere derechamente a su serviçio, por el grant afazimiento que ha con el señor,..." ${ }^{20}$. Atendiendo a todos estos aspectos, afirmaba este mismo autor, “... si el despensero es tal que guarde todo esto commo debe, puede servir mucho al señor et aprovechar mucho a las gentes que biven en su casa, et aun a todos los otros (que biven) por do el señor ha de andar" ${ }^{21}$.

De esta manera, y junto al prestigio curial ya mencionado, el oficio también ganó peso institucional y así, durante el reinado de Sancho IV ya se documentan los primeros despenseros con la denominación de mayores ${ }^{22}$, oficio, con la categoría de mayor, que ya disfrutaba en 1294 el infante Fernando, heredero al trono castellano ${ }^{23}$. De un siglo antes, en tiempos de Alfonso VIII, y siguiendo los mismos pasos, son las primeras noticias relacionadas con despenseros propios, aún no mayores, trabajando en la Casa de las reinas consortes castellanas ${ }^{24}$.

Por su parte, del siglo XIII son los primeros testimonios de despenseros mayores actuando en otros ámbitos áulicos castellanos, primero en la corte primada de los arzobispos de Toledo ${ }^{25}$, y algo más tarde, en la de algunos nobles castellanos como Don Juan Manuel y Juan Sánchez Manuel, conde de Carrión y adelantado mayor del rey en el Reino de Murcia ${ }^{26}$.

Sin embargo, y a pesar del prestigio institucional del oficio, éste no figura en la ordenanza de Enrique II dada en Toro de 1371 en la que se detallan las tasas de cancillería

\footnotetext{
${ }^{19}$ Partidas II,9,13.

${ }^{20}$ Don Juan Manuel, Libro de los estados..., pp. 289-290.

${ }^{21}$ Don Juan Manuel, Libro de los estados..., p. 290.

${ }^{22}$ Martín Gil de Aguilero y Juan Bernalt lo fueron de Sancho IV. Por su parte, Fernández Martínez y Don Moisés lo serían de María de Molina. Jaime de Salazar y Acha, La casa ..., p. 289; Archivo de Santa Inés de Écija, Leg. 4, doc. 15.

${ }^{23}$ El oficio recayó en Alfon Michel, también sobrecogedor de León, Mansilla, Mayorga, Villalpando, Toro, Zamora, Salamanca, Alba de Tormes, Ledesma y Ribacecoa. Asunción López Dapena, Cuentas y gastos (1292-1294) del rey D. Sancho IV el Bravo (1284-1295), Córdoba, 1984, p. 418.

${ }^{24}$ Francisco de Paula Cañas Gálvez, "Las Casas....", pp. 46-48.

${ }^{25}$ Por ejemplo, Pedro Pérez Bonet, que había sido escribano (1272), despensero mayor (1274) y mayordomo (1274) del arzobispo de Toledo Sancho de Aragón. A ello había de unir su condición de canónigo de Toledo (1274-1279). ac, Toledo, I.10.A.1.4; O.12.B.1.8; V.11.B.1.22; O.12.B.1.13; I.7.G.1.12; y V.3.A.1.31. ${ }^{26}$ Véase Don Juan Manuel, Libro de los estados...., pp. 289-291. Sabemos que entre los años 1371 y 1382 dos miembros de la familia judía Aventuriel, Mayr y Mosé, fueron despenseros mayores de Juan Sánchez Manuel, conde de Carrión y adelantado mayor del rey en el Reino de Murcia. En 1382 Mosé era también almojarife del conde. En cartas reales de 1371, mayo, 20. Valladolid, y 1382, enero, 13. Documentos de Enrique II, (Edición de Lope Pascual Martínez), Murcia, 1983, doc. CXV, pp. 169-172; y Documentos del siglo XIV (3), Edición de Francisco de Asís Veas Arteseros, Murcia, 1990, doc. XCIX, pp. 126-127. Sobre los despenseros de los Duques de Alba en el siglo XV es de referencia la obra de José Manuel Calderón Ortega, El ducado de Alba. La evolución histórica, el gobierno y la hacienda de un estado señorial (siglos XIV-XVI), Madrid, 2005, pp. 258-261.
} 
que deberían pagar los oficiales regios, seguramente por los despenseros eran oficiales reales cuyos "ofiçios.... No lleuaren cartas" 27 . Tampoco parece que fuera necesaria condición hidalga para ejercerlo, al menos hasta tiempos de Juan II o Enrique IV ${ }^{28}$.

En lo concerniente a sus competencias, sabemos que el despensero era el encargado de guardar la llave de la despensa real y entre sus demás obligaciones estaba la de revisar diariamente la calidad de las carnes y pescados que se adquirían en los mercados por compradores reales con destino a la cocina del soberano para que no existiera “... suspició de mesclar coses nocives hi”"29. Por ello, tanto Don Juan Manuel en su Libro de los Estados, como Martín Pérez en su Libro de las confesiones, hacían un especial hincapié en el cuidado que habría de ponerse en la elección de los despenseros, ya que si el despensero “... fuere cobdiçioso o de mala alma o de mal entençión, puede fazer muchas malas obras... puede fazer engaño en las mercas et en las conpras, poniendo que lo mercan et lo conpran por mayor preçio de lo que es verdat, et tomando de la vianda del señor más de la de su raçión..." ${ }^{30}$. Prácticas tan nocivas como dar

... malas carnes e tomando las buenas, e a las vegadas conpran las carnes que desechan los judios, e asífazen muchos engaños: el primero, furto o robo; el segundo que dan a sus christianos con que enferman o mueren; el tercero, que pasan la ley de santa Iglesia que vieda comer e bever de las viandas de los judios e darlas a sus christianos, mayormente las que ellos desechan.

estaban a la orden del día ${ }^{31}$. El elenco de excesos fue, sin embargo, aún mayor, como evidencia la documentación. En las Cortes de Valladolid de 1442 los procuradores se quejaron ante el rey del daño que causaban las especulaciones obradas por los despenseros "e sus ofiçiales" de "los sennores Reyna e Prinçipe e Prinçesa e de los otros sennores" cuando revendían a un precio mucho mayor a terceras personas las viandas que en principio se habían comprado a un precio más bajo para el servicio de la corte ${ }^{32}$. Juan II, consciente de estos despropósitos, ordenó con determinación

\footnotetext{
${ }^{27}$ El resto de los oficios cortesanos quedaron entonces divididos de la siguiente manera: "ofiçiales de la casa del Rey que se non trabajen de juridiçion", "ofiçios syn juridiçion de fuera de la casa del Rey", "ofiçiales de la cada del Rey que han juridiçion e poder para fazer justiçia", "grandes ofiçios de fuera de la casa del Rey con juridiçion" y "ofiçiales que ponen por sy los ofiçiales mayores, asy de la casa del rey commo de fuera". Cortes de los antiguos reinos de León y de Castilla, Vol. II, Madrid, Real Academia de la Historia, Madrid, 1863, pp. 233-235.

${ }^{28}$ Francisco de Paula Cañas Gálvez, "La Casa...”, p. 155. A finales del siglo XV sabemos, no obstante, que Pedro de Arzeo, despensero mayor del príncipe Don Juan, era "ombre hidalgo e criado antiguo de la Casa Real". Gonzalo Fernández de Oviedo, Libro..., p. 271.

${ }^{29}$ Ordinacions..., p. 73.

${ }^{30}$ Don Juan Manuel, Libro de los estados..., pp. 290-291.

${ }^{31}$ Martín Pérez, Libro de las confesiones. Una radiografía de la sociedad medieval española, Madrid, 2003, p. 463.

${ }^{32}$ Los procuradores alegaron ante el rey que los despenseros “.... Usan muy suelta mente de sus ofiçios, que toman caças e pescados e frutas e otras cosas semejantes, que se vienen a vender a la corte so color
} 
que en lo sucesivo los autores de estos desmanes la vez primera que se excedieran en sus labores, y en el caso de ser "persona de estado", perdieran sus raciones y quitaciones que del rey percibieran; la segunda, la mitad de sus bienes; y la tercera, la más dura de todas ellas, sería expulsado de la corte a perpetuidad. Si el infractor fuera de "menor manera" la primera vez estaría "sesenta dias en la cadena"; la segunda, recibiría sesenta azotes y la tercera sería "echado de la mi corte para sienpre"33.

Entre los alimentos que nunca deberían faltar en la despensa del rey figuraban el azúcar, gengibre y otras especias molidas, miel, aceite, tocino, quesos, pescados salados, vinagre "... e d'altres coses semblants menjadores als dits menjars pertanyents, quie sens dubte de cotidiana destribució se poran e han acostumat de reservar" ${ }^{\prime 4}$, lista que amplía notablemente Enrique de Villena en su Arte Cisoria con otros productos como las aves ${ }^{35}$, "animalias de cuatro pies" ${ }^{36}$, pescados selectos ${ }^{37}$, "reptilias" ${ }^{38}$, frutas ${ }^{39}$ y "yervas" 40.

Cuando faltaba alguno de estos manjares, el despensero era el encargado de comunicarlo a los compradores para que de forma inmediata subsanaran esa carencia ${ }^{41}$. En Castilla, para este trabajo de adquisición de los alimentos necesarios, se documenta, ya en tiempos de los Reyes Católicos, la figura del veedor de la Casa del rey ${ }^{42}$,

que lo quieren para vuestra alteza o para los dichos sennores, por pequennos presçios e despues lo venden e lo dan a otros que los vendan por ellos a mucho mayores preçios, o lo rreparten a quien quieren...". Cortes de los antiguos reinos de León y de Castilla, vol. III, Madrid, 1866, p. 431.

${ }^{33}$ Cortes..., III, p. 431.

${ }^{34}$ Ordinacions..., p. 73. Se trata, en líneas generales, de los mismos alimentos que Don Juan Manuel aconseja tomar a su hijo Fernando en el Libro Infinido: "Otrosí, usad todas las viandas de carnes et de pescados, et de vianda de leche et de fructa et de ortalizas et d salsas et de specias et de confites...". Don Juan Manuel, Libro infinido (Edición de Carlos Mota), Madrid, 2003, p. 130.

${ }^{35}$ Entre otras: pavones, faisanes, francolines, grullas, ansares, ánades, perdices, pollos o gallinas. Enrique de Villena, Obras completas. I. Arte Cisoria, Madrid, 1994, p. 164.

${ }^{36}$ Bueyes, vacas, búfalos (según Villena, estos animales provenían de Granada), liebres, conejos, cabras monteses, lechones, cerdos, cabritos, carneros.... Enrique de Villena, Arte Cisoria ..., p. 164.

${ }^{37}$ Lenguados, ballenas, meros, congrios, morenas, anguilas, salmones, sardinas, lampreas, langostas, langostinos, salmonetes, pulpos... Enrique de Villena, Arte Cisoria ..., pp. 164-165.

${ }^{38}$ Caracoles, galápagos y "tales". Enrique de Villena, Arte Cisoria ..., p. 165.

${ }^{39}$ Melones, pepinos, granadas, higos, uvas, piñones, castañas, nueces... Enrique de Villena, Arte Cisoria..., p. 165.

${ }^{40}$ Zanahorias, lechugas, nabos, cebollas, ajos, alcaparras... Enrique de Villena, Arte Cisoria ..., p. 165.

${ }^{41}$ Ordinacions..., p. 73.

${ }^{42}$ Pedro Patiño fue recibido como tal en la corte desde el 8 de diciembre de 1502 con una ración y quitación anuales que sumaban 30.000 maravedíes y que le serían librados desde el 1 de enero de 1503. La Casa de Isabel la Católica (Edición preparada y anotada por Antonio de la Torre), Madrid, 1954, p. 134. Por su parte, Pero Sánchez del Castillo aparecía en 1388 como veedor de la Casa de Juan I, quizá como veedor de las peticiones, oficio que compartió con Pero López en la Casa del infante Enrique cuando fue constituida por el rey en su testamento (1385), si atendemos a su formación jurídica (oidor de la Audiencia Real, doctor en leyes y más tarde contador mayor de Enrique III). En 1407, Pero Sánchez, sin duda el mismo Pero Sánchez del Castillo, era contador de la despensa de Juan II y formó parte de una embajada cuyo objetivo fundamental fue tratar la paz fronteriza entre Portugal y Castilla. A partir 
oficial que examinaba los precios y calidades de los alimentos y aconsejaba al despensero acerca de la conveniencia de la elección de unos u otros productos, además de vigilar todo lo necesario ("pan e vino, e agua, e fructa, e rávanos e otros refrescos") para el servicio de mesa del soberano ${ }^{43}$, competencia ésta, que en tiempos de Juan II recaía en exlusiva en el despensero mayor de la mesa del rey y su consiguiente entramado burocrático-administrativo ${ }^{44}$.

Tanto en las comidas ordinarias del rey como en los grandes banquetes, los despenseros trabajaban en estrecha conexión con los oficiales destinados a solemnizar las comidas (maestresalas, coperos, trinchantes, ministriles), el cocinero mayor, sus subordinados, los cocineros ordinarios y los demás proveedores encargados de abastecer a la corte de alimentos como eran los carniceros, pescaderos, fruteros, panaderos y aguadores para que no faltase de nada en la mesa regia ${ }^{45}$.

La labor doméstica y burocrático-administrativa de los despenseros recaía, al menos en el caso de Castilla, bajo la autoridad suprema y el control de los mayordo-

de 1409 parece que intervino, junto a Alonso de Salamanca y Alfonso Fernández de Sevilla, en la formación intelectual de Îñigo López de Mendoza. Pero López de Ayala, Crónica del rey Don Juan, primero de Castilla e de León (Edición, prólogo y notas de José-Luis Martín), Barcelona, 1991, p. 777. Más datos sobre López del Castillo en agn, Comptos, Carp. 57, n 11; Francisco de Paula Cañas Gálvez, Burocracia ..., pp. 262-264; y "La Casa de Juan I de Castilla...", p. 141. Como contador de la despensa del rey aparece en Alvar García de Santa María, Le parti inedite della "Crónica de Juan II" di Álvar García de Santa María (Edizione critica, introduzione e note a cura di Donatella Ferro), Venezia, 1972. p. 49. Marqués de Santillana, Obras completas (Edición de Manuel Durán), vol. II, Madrid, 1987, p. 8. Pero Sánchez del Castillo pertenecía a una importante familia de oficiales al servicio de la realeza Trastámara en la que figuraron nombres como los de Alfonso Sánchez del Castillo, canciller de Juan II y escribano del número de la ciudad de Zamora (†ca. 1450); Fernando Sánchez del Castillo, escribano de cámara de Juan II (14481450); y su homónimo Pero Sánchez del Castillo, escribano de cámara de Juan II, notario público, escribano de cámara residente en el Consejo Real de Juan II, escribano de los procuradores (1447-1465) y escribano mayor de las Cortes (1469). Francisco de Paula Cañas Gálvez, Burocracia ..., pp. 238 y 450-452.

43 “... el qual (oficio) es andar sobre los despenseros menores e compradores, e saber los presçios de lo que se compra para la despensa, e tener mucho aviso en que ande verdad en los gastos hordinarios, e que la cuenta se le tome al que gasta cada día, porque no aya fraude en ella; e que lo que fuere para la mesa del prínçipe sea muy bueno, e lo haga buscar e traer con diligençia e mucha limpieza;...". Gonzalo Fernández de Oviedo, Libro..., p. 126. También Miguel Ángel Ladero Quesada, “La Casa Real...”, p. 334. ${ }^{44}$ Despensero mayor de la mesa del rey (Juan de Torres, 1448), despensero de la mesa del rey (Fernando de Torres, 1448) y contador de la despensa del rey (¿Martín Ruiz?, 1454).

${ }^{45}$ Sobre estos oficiales véanse los trabajos de Miguel Ángel Ladero Quesada, "La Casa Real...", pp. 334-336; Jaime de Salazar y Acha, La casa ..., pp. 265-293; Francisco de Paula Cañas Gálvez, "La cámara...", pp. 103-117; y "La Casa de Juan I...”, pp. 153-155; María del Cristo González Marrero, La Casa ..., pp. 82-86; y Gonzalo Fernández de Oviedo, Libro..., pp. 119-120, 124, 130 y 132-133. H. Grassotti, "El repostero en León y Castilla (Siglos XII-XIV), Cuadernos de Historia de España, LXIX, 1987, pp. 41-75. Para Navarra y Aragón son de obligada referencia el libro de Fernando Serrano Larráyoz, La Mesa del Rey. Cocina y régimen alimentario en la corte de Carlos III el Noble de Navarra (1411-1425), Pamplona, 2002 y La alimentación en la Corona de Aragón (Siglos XIV-XV), M. García Guatas, E. Piedrafita y J. Barbacil (Coords.), Zaragoza, 2013 respectivamente, con abundante bibliografía complementaria en ambas publicaciones. 
mos mayores y sus lugartenientes ${ }^{46}$, como así especifican las Partidas $^{47}$ y con posterioridad una información aportada en 1490 por Juan de León a petición del comendador Gonzalo Chacón acerca de las cosas y casos en los que entendían el mayordomo mayor y el contador mayor de la despensa y raciones de la Casa de Juan $\mathrm{II}^{48}$, documento que abunda sobre el modo de actuar de sus respectivos lugartenientes y el orden que tenía el despensero en escribir el libro del gasto de la despensa regia y otros documentos de tipo contable ${ }^{49}$.

En ese interesante testimonio se asegura que:

... en tienpo de dicho rey don Juan que el mayordomo mayor e su lugartenyente en su nonbre mandauan a todos los ofiçiales de la casa del dicho rey et que ellos fazían todo lo

\footnotetext{
${ }^{46}$ Sobre el papel de estos oficiales véase Espéculo II,13,2. “... los mayordomos mayores del rey.... tienen muy grant logar en casa del rey”. "... cuyo nombre en sí él mismo dize que es el mayor de la casa, entre los ofiçiales della, en el serviçio de la persona real". Gonzalo Fernández de Oviedo, Libro... , pp. 83-84: David Torres Sanz, La administración central castellana en la Baja Edad Media, Valladolid, 1982, pp. 76-82; Miguel Ángel Ladero Quesada, "La Casa Real...”, pp. 333-336; y Jaime de Salazar y Acha, La casa ..., pp. 163-192. Para los mayordomos regios en tiempos de Juan I véanse de Francisco de Paula Cañas Gálvez, "Structure...", pp. 113-129 y "La Casa de Juan I...", pp. 141-144. Los mayordomos de las reinas consortes castellanas del siglo XV en Francisco de Paula Cañas Gálvez, "Las Casas....", pp. 41-46. Para las cortes de Aragón y Navarra (Maestre del Hostal, en el caso navarro) nos remitimos a Ordinacions..., pp. 53-57, y María Narbona Cárceles, La corte de Carlos III el Noble, rey de Navarra: espacio doméstico y escenario del poder, 1376-1415, Pamplona, 2006, pp. 168-172 respectivamente.

47 "Mayordomo es el que dirije la cuenta de las cosas que son para mantenimiento del rey... debe tomar la cuenta a los oficiales de las despensas, saber lo que el rey manda dar, cómo se da y de qué manera". Partidas II, 9, 17.

48 "Información aportada por Juan de León a petición del comendador Gonzalo Chacón acerca de las cosas y casos en los que entendían el mayordomo mayor y el contador mayor de la despensa y raciones de la Casa de Juan II (1406-1454) sobre el modo de actuar de sus respectivos lugartenientes y el orden que tenía el despensero en escribir el libro del gasto de la despensa regia”. 1490, marzo, 15. Sevilla. AGS, CySR, Leg. 42, f. 5. Véase 5. Apéndice documental, doc. 45. Sobre ello González de Oviedo nos refiere que: "Este ofiçio (contador mayor de la despensa y raciones de la Casa del rey) tuvo Gonçalo Chacón, el Viejo, señor de Casarruvios del Monte, así de la casa de la Reina Católica como en la del prínçipe, e para después de los días de Chacón tenía merçed e expectativa del mismo ofiçio su nieto, don Gonçalo Chacón. Servía este ofiçio en la casa del prínçipe un hombre hijodalgo, de auctoridad e virtuoso, que se deçía Torres de Murçia”. Gonzalo Fernández de Oviedo, Libro..., p. 87. En enero de 1483 este oficio los ostentaba ya Juan Chacón, hermano de Gonzalo Chacón, nietos ambos de Chacón el Viejo, refiriéndose los monarcas a él como "nuestro criado e nuestro contador mayor de la despensa e raciones, del nuestro consejo". 1483, Enero, 6. Madrid. AM, Murcia, Cartulario Real 1478-1488, f. 95r-v, publicado en Documentos de los Reyes Católicos (1475-1481), (Edición de Andrea Moratalla Collado), Murcia, 2003, doc. 232, pp. 442-444.

${ }^{49}$ En 1421, por ejemplo, en una de las arcas que se custodiaban en la cámara del infante Juan de Aragón había un "... enboltorio que dise Cartas de pago de la despensa", y en otra de esas arcas unas "Cuentas de la espensa e de la casa del infante e de la cauallerisa...". Años más tarde, en 1445, y tras el fallecimiento de la reina María, quedó en su cámara "otra arca con çiertas escripturas vejas de despensa e otras cosas". AHN, Códices, 1.369, ff. 73v y 74v; y AMº, Guadalupe, Leg. 3 respectivamente.
} 
que por el mayordomo mayor o por su lugartenyente los era mandado, et que asýmysmo vido que mandaua al despensero todas las cosas que avía de fazer para seruiçio de la casa e despensa del dicho rey, et que sabe que el dicho mayordomo mayor o su lugartenyente en su nonbre mandauan dar qualquier cosa de las que auía en la dicha despensa o se traýa a ella o todo juntamente que se fasía syn que el contador mayor de la dicha despensa ni su lugartenyente entendiesen en ello et que quando venýan a estreuir la cuenta e tomarla al despensero que non tenýan poder de testar nyn quitar ninguna cosa del gasto de la dicha despensa más de quanto quitaua el mayordomo o su lugartenyente y que todo lo otro lo pasauan y contauan como el mayordomo mandau $a^{50}$.

La labor en la despensa del mayordomo era apoyada por un contador de la despensa y era, según los procuradores reunidos en Valladolid en 1451, esencial para “... que más sin trabajo podiese sacar los libramientos dello e fuesen libradas (las raciones)..."

Las competencias económicas asumidas por los despenseros revelan la importancia institucional y complejidad técnica del oficio. Sabemos que eran los responsables de "... tomar cuenta de todos los offiçiales, tambien de los que fazen las despensas de la corte" ${ }^{52}$, y era, según Don Juan Manuel, el encargado de

... recaudar las alcabalas de los oficiales por lo que reciben tomándoles cuenta diaria de ello, llevar consignado en un libro el gasto de la despensa regia y además contaba con facultad para poder castigar a los oficiales que cometieran alguna falta.

y, lo que más nos interesa ahora, “... repartir las raciones de todas las personas que comían en palacio, incluso pobres cuando era voluntad del Rey”53, función esta

\footnotetext{
${ }^{50}$ 1490, marzo, 15. Sevilla. Dos documentos coetáneos de Juan II de enero y febrero de 1454, conservados en el Archivo General de Simancas, confirman estas prácticas. Se trata de sendos informes firmados por el mayordomo y contador de la despensa de la mesa del rey seguramente Rodrigo de Castañeda y Martín Ruiz, los suscribientes) sobre el número de bestias por mes que estuvieron en la caballeriza real entre septiembre y diciembre de 1453. AGS, CySR, Leg. 42, f. 5. 1454, enero, 25, y 1454, febrero, 28. AGS, CySR, leg. 42, f. 1m. 5. Los documentos en 5. Apéndice Documental, docs. 18 y 26. Sobre la caballeriza real en tiempos de Juan II destacamos una interesante carta misiva de Juan II al concejo de Jerez de la Frontera por la que el rey, argumentando que "... al presente la mi caualleriza esta menguada de buenos cauallos...", le ordenaba “... catar e buscar en esa çibdad un cauallo de la guisa que sea muy bueno e me lo enbiedes con el portador de la presente, por quanto yo me quiero seruir desa çibdad del dicho caballo...”. 1447, enero, 15, Madrigal de las Altas Torres. am, Jerez de la Frontera. AC. 1447, f. 14r., publicado por Juan Abellán Pérez, Diplomatario del Reino de Granada. Documentos de Juan II de Castilla (1407-1454) del Archivo Municipal de Jerez de la Frontera, Granada, 2011, doc. 254, p. 555. Sobre el pago a los caballerizos mayores en época de Juan II véase el albalá de Juan II ordenando a sus contadores mayores librar a Gómez de Hoyos, caballerizo mayor del rey, 19.890 maravedíes de las tasas que le correspondían de la caballeriza del rey y las dos acémilas con las que servía en dicha caballeriza en 1453. 1454, marzo, 6. AGS, CySR, leg. 42, f. 1m. También sobre la caballeriza real en este reinado Francisco de Paula Cañas Gálvez, El itinerario de la corte de Juan II de Castilla (1418-1454), Madrid, pp. 41-66.

${ }^{51}$ Cortes..., III, p. 586.

${ }^{52}$ Partidas II,9,17.

${ }^{53}$ Gonzalo Fernández de Oviedo, Libro..., pp. 127-128.
} 
última que, como seguidamente veremos, pasó a desempeñarla a finales del siglo XIV el despensero mayor de las raciones de la Casa del rey. Junto a todo ello, debía recaudar las alcabalas de los oficiales por lo que reciben tomándoles cuenta diaria de ello, llevar consignado en un libro el gasto de la despensa regia y facultad para poder castigar a los oficiales que cometieran alguna infracción ${ }^{54}$. Su rúbrica era además esencial para que, junto a las del tesorero y notario, se pudieran librar las cartas de "recabdamiento de los nuestros dineros (del rey $)^{55}$. La vinculación de los despenseros con la recaudación de tributos se estrecharía aún más a finales de aquel siglo, momento en el que un despensero real, Juan Núñez, aparecía como arrendador de las alcabalas del obispado de Cartagena y Reino de Murcia (1386 ${ }^{56}$.

Por el mencionado memorial de 1490 sabemos que los mayordomos mayores y sus lugartenientes controlaban directamente la redacción de estos libros:

... en el escreuir del libro del gasto de la dicha despensa que tenýan tal orden que se juntauan los lugarestenyentes de mayordomo e contador e yuan cada día a la despensa y alli escreuían todo lo que se auýa gastado y que sabe que cada vno dellos fazía su libro juntamente con el del despensero y que después de escritos que dexauan los libros en la despensa en vna arca et que después de escrito el gasto de cada día señalauan los lugarestenyentes el libro del despensero y en fyn de cada mes conçertauan todos tres libros que fazian sus feneçymientos y sacauan vna fe en linpio et en fyn de cada año fazían carta de cuenta e la lleuauan al mayordomo mayor e al contador y ellos la fyrmauan et que sabe que nunca en otra cosa entendía el dicho contador nin sy lugartenyente saluo en esto que tiene dicho.

En el caso de ausencia del lugarteniente del mayordomo mayor estuviera fuera y no pudiera atender personalmente el control de los libros de la despensa fuera el lugarteniente del mayordomo encargado de esa despensa el que debería consultar cualquier cuestión al mayordomo mayor y más tarde “... escreuía la cuenta e la pasaua y señalaua el libro y que después que venía el lugartenyente de mayordomo que señalaua aquella cuenta y la pasaua asý como la fallaua señalada del contador..."57.

Consta también que desde los reinados de Fernando IV y Alfonso XI los despenseros actuaron como cobradores de los yantares que algunas villas, ciudades y mo-

\footnotetext{
${ }^{54}$ Partidas II,9,13. Don Juan Manuel, Libro de los estados..., p. 290. Gonzalo Fernández de Oviedo, Libro..., pp. 127-128.

${ }^{55}$ En las Cortes de Toro de 1371 Enrique II dispuso que estas cartas fuesen libradas “... por mandado del nuestro notario e del nuestro thesorero o del nuestro espensero mayor, poniendo cada vno su sennal en la carta que mandaren librar; pero que estas cartas que mandaren librar, que se libren de la vista del notario e del chançeller". Cortes..., II, p. 218.

${ }^{56}$ Como tal aparece mencionado en la carta de Juan I ordenando recaudación de las alcabalas. 1388, enero, 15. Burgos. am, Murcia, Cartulario Real, 1384-1391, ff. 153v-154r. Documentos de Juan I (Edición de José Manuel Díez, Amparo Bejarano Rubio y Ángel Luis Molina Molina), Murcia, 2001, doc. 231, pp. 449-451.

${ }^{57}$ AGS, CySR, Leg. 42, f. 5.
} 
nasterios debían pagar cuando eran visitadas por la realeza, cantidades que en una provisión de 1350 Pedro I especificaba estar destinadas a la "mesa e comer de la mi casa" ${ }^{58}$. Se trataba, sin embargo, de funciones que en sus orígenes, durante los siglos plenomedievales, habían sido asumidas en su conjunto por los mayordomos mayores $^{59}$, pero con la creciente especialización de las tareas áulicas éstas pasaron a ser desempeñadas, seguramente en tiempos de Alfonso VIII ${ }^{60}$, por los despenseros, oficiales desde entonces especializados en las funciones económicas y de abastecimiento más arriba comentadas.

Con el desarrollo institucional experimentado en Castilla a lo largo del siglo XIV ${ }^{61}$, y muy particularmente tras la llegada al trono de Enrique II, la estructura de la despensa regia se fue haciendo cada vez más compleja, pero también más operativa y eficaz. En diciembre de 1379 sabemos que a las funciones ya consignadas por los despenseros habría que añadir y matizar la más arriba citada del reparto de las raciones de todas las personas que comían en palacio, ciñéndose esta obligación entonces ya únicamente al pago de raciones y quitaciones a algunos oficiales regios ${ }^{62}$. Poco más de dos años después, en abril de 1380, estas últimas funciones de pago de raciones eran desempeñadas en exclusiva por Ferrant Gascón, despensero mayor de las raciones de la Casa del rey ${ }^{63}$.

Desde ese momento y bajo la autoridad del despensero mayor, ya en tiempos de Juan I, la estructura institucional de la despensa del rey quedaba repartida en los siguientes oficios y oficiales:

\footnotetext{
${ }^{58}$ Cortes II, p. 188. Francisco de Paula Cañas Gálvez, Itinerario de Alfonso XI..., p. 24. Miguel Ángel Ladero Quesada, Fiscalidad..., pp. 223-224. Los titulares del oficio de despensero en tiempos de Pedro I en Luis Vicente Díaz Martín, Los oficiales de Pedro I de Castilla (2 ${ }^{\mathrm{a}}$ edición corregida y aumentada), Valladolid, 1987, pp. 81-82.

59 “... al Mayordomo pertenesçe tomar cuenta de todos los offiçiales, tambien de los que fazen las despensas de la corte". Partidas II,9,17.

${ }^{60}$ En 1191 Rodrigo Rodríguez de Palenzuela figuraba como despensero del rey de Castilla. Jaime de Salazar y Acha, La casa ..., p. 289.

${ }^{61}$ Un amplio listado de los despenseros mayores del rey de Castilla hasta tiempos de Juan I en Jaime de Salazar y Acha, La casa ..., pp. 523-526.

${ }^{62}$ 1380, enero, 8.AHNNob, Osuna, Carp. 40, n 1. Citado por Francisco de Paula Cañas Gálvez, "La Casa de Juan I...", p. 155.

${ }_{63}^{63}$ 1380, abril, 3. AHNNob, Osuna, Carp. 40, nº 1. Luis Suárez Fernández, Historia del reinado de Juan I de Castilla. Tomo II. Registro documental (1371-1383), Madrid, 1982, doc. 181, p. 289. El documento en el que se inserta esta partida es la carta de finiquito de las cuentas del camarero mayor Diego López de Estúñiga. 1380, diciembre, 20. Medina del Campo. Estas cuentas han sido objeto de diferentes publicaciones y estudios a cargo de Luis Suárez Fernández, Historia ... II, doc. 181, pp. 249-307; María Luisa Villalobos y Martínez-Pontrémuli, "Las gestiones hacendísticas de Diego López de Estúñiga camarero de Juan I (Contribución al estudio de la economía y fiscalidad castellana bajo los primeros Trastámara)", Hispania, XLIII, 1983, pp. 159-206; y Francisco de Paula Cañas Gálvez, "La Casa de Juan I...", pp. 133-180.
} 
TABLA 1

Oficios y oficiales de la despensa real en la corte de Juan I de Castilla (1374-1390) ${ }^{64}$

OFICIO

Despenseros mayores
TITULAR

Juan Núñez

Ferrant Gascón

Juan Gómez

Santiago García ${ }^{68}$

Alfonso García

Juan Rodríguez de

Cuenca $^{71}$

Despenseros mayores de las Ferrant Gascón

raciones de la Casa del rey

Despenseros

Despensero de los caballeros
Ferrant Gascón

¿Fernán Rodríguez?

Pedro Martínez

Sancho García

Juan de San Pedro
PERSONA REAL

FECHAS

Pedro I/Juan I 1351-1388

Juan I

Juan I

Juan I/Infante Enrique/

Enrique III

Infante Fernando

Leonor de Aragón

Juan I

Juan I

Juan I

Juan I

Juana Manuel

Juan I/Infante Enrique
$1374-1386^{66}$

$1379^{67}$

$1385 / 1392^{69}$

$1389^{70}$

1375-1382

$1380^{72}$

$1380^{73}$

$1380^{74}$

$1379^{75}$

$1380^{76}$

$1385^{77}$

${ }^{64}$ Los oficios adscritos a la Casa del infante Enrique van indicados según los dispuso Juan I en su testamento (1385). En ese momento, el rey no nombró ningún oficial de la despensa para el infante Fernando. Pero López de Ayala, Crónica del rey don Juan..., pp. 776-778 y 785. Francisco de Paula Cañas Gálvez, "La Casa de Juan I...”, pp. 138, 155 y 170.

${ }^{65}$ Salazar y Acha, La casa ..., p. 525; Francisco de Paula Cañas Gálvez, "La Casa de Juan I...”, p. 170.

${ }^{66}$ En marzo de 1386, sin hacer mención a su oficio de despensero mayor del rey, figuraba entre los oficiales que refrendaban una carta real de Juan I concediendo a Josén Gallarte Torner de Tolosa 40.000 maravedíes de juro. 1386, marzo, 9. Burgos (Inserta en confirmación de Enrique III, 1394, octubre, 26. Real sobre Gijón). El concejo de Valladolid en la Edad Media (1152-1399) (Transcripción y notas críticas por Fernando Pino Rebolledo), Valladolid, 1990, doc. nº 152, pp. 270-276.

${ }^{67}$ Francisco de Paula Cañas Gálvez, "La Casa de Juan I...”, p. 170.

${ }^{68}$ Aunque en la Crónica aparece consignado el nombre de Santiago García, no descartamos que en realidad se tratara de un error de lectura y el nombre real sea el de Sancho García, despensero de la reina Juana Manuel, despensero mayor del infante Enrique y más tarde despensero mayor de Enrique III.

${ }^{69}$ Salazar y Acha, La casa ..., p. 525; y Francisco de P. Cañas Gálvez, "La Casa de Juan I...”, p. 170.

${ }^{70}$ Como tal figura entre los testigos de la carta de poder otorgada por el concejo de Madrid para que se hiciera pleito-homenaje al rey León de Armenia como señor de Madrid. 1389, octubre, 2. Curiosamente este documento se encuentra todavía fechado por la datación de la era hispánica. Jerónimo de Quintana, A la muy antigua y coronada villa de Madrid, vol. II, Madrid, 1629, p. 315.

${ }^{71}$ Debió de servir a la reina hasta el fallecimiento de ésta en 1382.

72 1380, abril, 3. AHNNob, Osuna, Carp. 40, nº 1. L. Suárez Fernández, Historia ... II, doc. 181, p. 289.

${ }^{73}$ 1380, abril, 3. AHNNob, Osuna, Carp. 40, nº 1. L. Suárez Fernández, Historia ..., II, p. 289.

${ }^{74}$ AHN, Clero, Leg. 692, s/f.

${ }^{75}$ Francisco de P. Cañas Gálvez, "La Casa de Juan I...”, p. 170.

${ }^{76}$ En enero de 1380 recibió de Juan Núñez, despensero mayor de Juan I, 17.000 maravedíes para que le fueran entregados a doña Juana, además de otros 3.000 maravedíes más para la condesa, "fija del rey de Portogal". Pagados por albalá de 1380, enero, 8. AHNNob, Osuna, Carp. 40, nº 1.

${ }^{77}$ Pero López de Ayala, Crónica del rey don Juan..., pp. 776-778 y 785. Francisco de Paula Cañas Gálvez, “La Casa de Juan I...”, pp. 138, 139 y 170. 
OFICIO

Contador de la despensa
TITULAR

Ferrand Pérez de

Villafranca
PERSONA REAL

Infante Enrique
FECHAS

$1385^{78}$

Durante los reinados de Enrique III y Juan II ${ }^{79}$, y como como consecuencia del mencionado y exitoso proceso de reformas político-administrativas impulsadas por la Corona, la despensa multiplicó sus oficios y oficiales apareciendo entonces junto a los ya existentes despenseros mayores, despenseros ordinarios y despenseros de los caballeros, el mencionado despensero mayor de las raciones de la Casa del rey, los contadores mayores y ordinarios de la despensa además de otros oficios de nuevo cuño, centrados principalmente en la gestión económica de la despensa regia, como los del servidor de la despensa, contador de la despensa y raciones de la Casa del rey, oficio, éste último, primero, en tiempos de Juan II, con la categoría de ordinario, y después, ya durante los reinados de Enrique IV y Alfonso XII, de mayor, según vemos en la siguiente tabla:

TABLA 2

Oficios y oficiales de la despensa del rey de Castilla (1397-1468) OFICIO

Despenseros mayores
OFICIAL

Ruy González de Medina Sancho García ${ }^{80}$

Juan de Sala ${ }^{81}$

Fernando de Torres ${ }^{82}$

Gonzalo Messía de

Virúes $^{84}$
REY

FECHAS

Enrique III

Enrique III

ca. 1390-1406

1394

Enrique III

Juan II

1397-1398

$1415-1428^{83}$

† a. 1448

Juan II

ca. 1450

\footnotetext{
${ }^{78}$ Pero López de Ayala, Crónica del rey don Juan..., pp. 776-778 y 785. Francisco de Paula Cañas Gálvez, "La Casa de Juan I...”, pp. 138, 139 y 170.

${ }^{79}$ Sobre la figura de los despenseros reales durante los años de la minoría de edad de Juan II, véase el trabajo de Santiago González Sánchez, La Corona de Castilla: vida política (1406-1420), acontecimientos, tendencias y estructuras, Tesis Doctoral inédita, Madrid, 2010, p. 1.184.

${ }^{80}$ 1394, agosto, 15. Paredes. AM, Tordesillas, en traslado de 1395, abril, 8. Tordesillas. Jonás Castro Toledo, Colección diplomática de Tordesillas, (900-1474), Valladolid, 1981, doc. 314, pp. 190-192.

${ }^{81}$ David Nogales Rincón, "Un año en la Corte de Enrique III (1397-1398)", En la España Medieval, 37, 2014, p. 88.

${ }^{82}$ Gozó en vida de, al menos, 1.500 maravedíes y 6 excusados. Casado con Leonor de Tovar, padre de Catalina de Castañeda, beneficiaria de una merced vitalicia de 7.500 maravedíes (1452-1460), y de Fernando de Tovar, con una merced, también vitalicia de 9.000 maravedíes (1452-1458). AGS, MYP, Leg. 2, ff. 183 y 405; MYP, Leg. 48, f. 44; y MYP, Leg. 112, f. 122, respectivamente.

${ }^{83}$ Como tal aparece junto a su esposa, Leonor de Tovar, en la carta de venta de unas casas en Guadalajara, en la colación de San Esteban, calle de los Matutes, a favor de Alfonso Núñez de Toledo. Ante Alfonso Ruiz del Castillo, escribano. 1428, abril, 15. AHNNob, Griegos, Carp. 8, doc. 59.

${ }^{84}$ Regidor de Segovia, guarda y vasallo de Juan II. Hijo de Fernán Sánchez de Virués, también regidor segoviano, y de Mayor de Pédrola. Contrajo matrimonio con Catalina Ruiz de Tapia y después con
} 
OFICIO

Despenseros mayores de las raciones de la Casa del rey
Despensero mayor de la mesa del rey

Despenseros
OFICIAL

Lope Fernández de

Valladolid $^{82}$

Juan Sánchez de

(Salazar)

Juan García de Soria ${ }^{86}$

Luis García de Morales

Juan de Torres ${ }^{87}$

Luis González

Pedro de Madrid ${ }^{89}$

Juan de León ${ }^{91}$

Pedro de Arévalo ${ }^{92}$

Alfonso de Almagro ${ }^{93}$

Despensero de la mesa del rey Fernando de Torres ${ }^{94}$

Despenseros de las raciones

de la Casa del rey
Lope Fernández de

(Valladolid) ${ }^{95}$

Juan Sánchez de

Salazar $^{96}$
REY

Enrique III

Juan II

Juan II

Juan II

Juan II

Juan II

Juan II

Enrique IV

Enrique IV

Alfonso XII

Juan II

Enrique III

Enrique III
FECHAS

1392

1408

¿1419?

$/ 1429 / \uparrow 1446$

$1452-\uparrow 1456$

1448

$1407^{88}$

$1453^{90}$

1462

1466

1465-1466

1448

1392

1397

María de Guzmán. Juan Román y Cárdenas, Noticias genealógicas del linaje de Segovia, s/d, pp. 240 241. Citado por Jaime de Salazar y Acha, La casa ..., p. 526.

${ }^{85}$ 1394, agosto, 15. Paredes. AM, Tordesillas (En traslado de 1395, abril, 8. Tordesillas). Jonás Castro Toledo, Colección..., doc. 313, pp. 189-190.

${ }^{86}$ Francisco de Paula Cañas Gálvez, Burocracia ..., pp. 346-347.

${ }^{87}$ Vecino de Guadalajara, hijo del despensero Fernando de Torres, fiador con 300.000 maravedíes de Diego Alfonso de Sevilla, recaudador y arrendador mayor de las alcabalas del arcedianato de Guadalajara. Pablo Ortego Rico, Hacienda, poder real y sociedad en Toledo y su reino (siglo XV-principios del XVI), Tesis Doctoral inédita, Madrid, Universidad Complutense, 2013, vol. 1, p. 961.

${ }^{88}$ Como tal aparece entre los testigos que firman el testimonio notarial de cómo Gonzalo Pérez Fajardo procurador de la ciudad de Murcia, juró y reconoció como rey a Juan II. 1407, febrero, 21. Segovia. AGS, PR, leg. 58, $\mathrm{n}^{\circ}$ 45. AM, Murcia, Cartulario Real 1392-1412, ff. 11v-12v, publicado por Juan Torres Fontes, "Las Cortes castellanas en la menor edad de Juan II", Anales de la Universidad de Murcia, XXI, 1961-1962, pp. 69-71.

${ }^{89}$ Quizá el mismo Pedro de Madrid que en 1453 era vasallo del rey y aseguraba ser hijo de Diego Arias Dávila. Tenía del rey por merced vitalicia 1.500 maravedíes desde 1453. Hay libranzas hasta 1463. AGS, MYP, Leg. 76, f. 32.

${ }^{90}$ Fecha en la que Juan II le entregó el oficio de escribanía de rentas de Alcaraz que desempeñaría junto al escribano de cámara Juan González de Ciudad Real. Francisco de P. Cañas Gálvez, Burocracia ..., p. 408.

${ }^{91}$ Miguel Ángel Ladero Quesada, “1462...”, p. 261.

${ }^{92} \mathrm{Su}$ hijo Gabriel de Arévalo fue tomado por doncel de Enrique IV en 1466. AGS, QC, Leg. 3, f. 223.

${ }^{93}$ AGS, QC, Leg. 2, ff. 7 y 9.

${ }^{94}$ AGS, EMR, Leg. 2, f. 378r-v.

${ }^{95}$ Francisco Layna Serrano, Historia de Guadalajara y sus Mendozas en los siglos XV y XVI, Madrid, 1942 , pp. 42 y 297.

${ }^{96}$ David Nogales Rincón, “Un año...”, p. 89. Entre 1407 y 1410 aparece como Juan Sánchez y despensero mayor de las raciones de la Casa del rey; suponemos que se trata del mismo Juan Sánchez de Salazar. 
OFICIO

Contadores mayores de la despensa

Contador de la despensa

Contador de la despensa

y raciones de la Casa del rey

Contador mayor de

las raciones de la Casa del rey Diego Romero ${ }^{101}$

Contador de raciones del rey
Pedro de Hontiveros ${ }^{102}$

Juan de Hontiveros ${ }^{103}$

OFICIAL

Pedro de Luna ${ }^{97}$

Alfonso González de la

$\mathrm{Hoz}$

Pero Sánchez del

Castillo $^{98}$

Fernando $^{99}$

Diego Romero ${ }^{100}$

Benito Sánchez de

Salamanca $^{104}$
REY

FECHAS

Juan II

Juan II/

Enrique IV

Juan II

1407

Enrique IV

1462

Juan II

1444

Juan II/

Enrique IV

Alfonso

de Trastámara † marzo 1468

Alfonso

de Trastámara

desde marzo

de 1468

Enrique IV

1455

${ }^{97}$ Ese mismo año su hermano Juan de Luna era copero mayor de Juan II. Ambos, Pedro y Juan, eran hijos de Álvaro de Luna. RAH, Salazar, M-5, f. 280v.

${ }^{98}$ Aparecía en 1407 también como refrendario y oidor de la Audiencia Real. Suponemos que se trata de Pero Sánchez del Castillo a quien ya vimos en 1388 desempeñando el oficio de Veedor de la Casa del rey.

${ }^{99}$ Miguel Ángel Ladero Quesada, “1462...”, pp. 247 y 268. Alguna lectura, quizá errónea, le sitúa en esa fecha como "catador" mayor de la despensa y raciones de la Casa del rey. Francisco de Paula Cañas Gálvez, "Pacto...", p. 338.

${ }^{100}$ En el actor de la firma por Juan II de Castilla y Alfonso V de Aragón para guardar los acuerdos de paz alcanzados entre ambos monarcas, Romero ya figura como contador de la despensa y raciones de la Casa del rey de Castilla. 1444, octubre, 20. Con este mismo oficio aparece mencionado en las Cortes de Valladolid de 1451. Burgos, rah, Salazar, K-81; Cortes..., III, p. 588.

${ }^{101}$ En las Cortes de Valladolid de 1451 parece que ya era contador mayor de la despensa y raciones de la Casa del rey si tenemos en cuenta que fue el responsable de dar explicaciones ante el monarca sobre los derechos percibidos por estos contadores. AGS, MYP, Leg. 104, fol. 158; Cortes..., III, p. 588.

${ }^{102}$ En 30 de marzo de 1468 ya había fallecido, fecha en la que Alfonso XII nombra a su hijo Juan de Hontiveros con el mismo oficio de contador mayor de la despensa y raciones de la Casa del rey. AGS, QC, Leg. 3, ff. 610-612. Dionisia Rodríguez García, Documentación de Don Alfonso de Trastámara en el Archivo General de Simancas (1460-1468), Valladolid, 1981, doc. 336, p. 56.

${ }^{103}$ Nombramiento por fallecimiento de su padre, Pedro de Hontiveros. 1468, marzo, 30. Arévalo. AGS, QC, Leg. 3, ff. 610-612. Dionisia Rodríguez García, Documentación..., docs. 335 y 336, p. 56.

${ }^{104}$ Escribano de la notaría de Andalucía (1440), escribano de cámara (1441) y escribano de los privilegios (1442), mayordomo en Madrid y su arciprestazgo del arzobispo de Toledo Alfonso Carrillo (1449-1452). Seguramente estuvo emparentado con Pero Sánchez de Salamanca, Escribano del arzobispo Sancho de Rojas (1417-1419), escribano de cámara (1422), escribano del Consejo Real de Juan II (1453) y notario público (1422). Francisco de Paula Cañas Gálvez, Burocracia ..., pp. 457-458; Tomás Puñal Fernández, El registro de la documentación notarial del concejo de la villa y Tierra de Madrid (1449-1462), Madrid, 
OFICIO

Contador de la despensa

de la mesa del rey

Servidor de la despensa
OFICIAL

¿Martín Ruiz? ${ }^{105}$

Juan de Chillón ${ }^{106}$
REY

Juan II

Juan II
FECHAS

1454

$1453-1454$

Cada miembro de la

Familia Real tenía, como podemos comprobar en las siguientes tablas, sus correspondientes despensas con los respectivos oficiales que las atendían, aunque tanto en el caso de las reinas consortes, como de los infantes y Príncipe de Asturias no hemos podido documentar la existencia de sus despenseros mayores de las raciones de sus respectivas casas, al menos hasta el reinado de los Reyes Católicos, período en el que sabemos que en la Casa del príncipe don Juan el oficio de despensero mayor de las raciones del príncipe era atendido por Juan Ramírez $(1497)^{107}$, mientras que la mayordomía de la despensa y raciones lo era por Pedro Patiño (1497) ${ }^{108}$ y el de contador mayor de la despensa y raciones, lo fue por Gonzalo Chacón y Torres de Murcia ${ }^{109}$.

En el caso de Catalina de Lancaster sabemos que las órdenes de pago de los recaudadores a los tesoreros para abonar las correspondientes raciones y quitaciones de su Casa fueron firmadas por Enrique III, receloso siempre del entorno petrista que rodeaba a la reina ${ }^{110}$, y el abono de estas cantidades, al parecer, no era satisfecho por el despensero mayor de las raciones de la Casa de la reina, quizá porque este oficio no existiese en su Casa, sino por su tesorero, quien, una vez recibido el dinero, ordenaba al recaudador mayor que lo librase a sus destinatarios. En junio de 1392, por ejemplo, el rey encargó a Juan Alfonso de Ocaña, su recaudador mayor en el obispado de Cuenca, entregar a Antón Sánchez de Villarreal, tesorero mayor y recaudador de

2005, docs. 1099 y 5092, pp. 492 y 594-595; y María del Mar García Guzmán, Colección diplomática del Adelantamiento de Cazorla (1231-1495), Cádiz, 1991, docs. 115-118 y 120, pp. 133-146.

${ }^{105}$ AGS, CySR, leg. 42, f. $1 \mathrm{~m}$.

${ }^{106}$ Francisco de Paula Cañas Gálvez, Burocracia ..., p. 292.

${ }^{107}$ Rosana de Andrés Díaz, El último decenio del reinado de Isabel I a través de la tesorería de Alonso de Morales (1495-1504), Valladolid, 2004, p. 224.

${ }^{108}$ Rosana de Andrés Díaz, El último...., p. 157.

${ }^{109}$ Gonzalo Fernández de Oviedo, Libro...., p. 87. Para profundizar en la dinámica de los pagos a los oficiales que sirvieron en la corte del príncipe Juan nos remitimos al trabajo de José Damián González Arce, "Trabajar...", pp. 777-842. Por su parte, en la Corte de los Reyes Católicos también se documenta un secretario y despensero mayor de las raciones de los oficiales, oficio que entre al menos 1485 y 1496 recayó en Francisco Ramírez de Madrid. Entre al menos 1501 y 1503, el hijo de Francisco, Fernand Ramírez de Madrid, aparecía como comendador y despensero mayor de las raciones de la Casa Real. AGS, RGS, vii-1485, f. 45; AGS, RGS, vi-1501, f. 74; Rosana de Andrés Díaz, El último...., pp. 34 y 45; y La Casa de Isabel la Católica..., p. 134. Más datos biográficos sobre Francisco y su hijo Fernand en Pedro Andrés Porras Arboledas, "El secretario...”, pp. 169-182; Francisco Ramírez..., pp. 1-400; y José Damián González Arce, "Trabajar...”, pp. 782 y 786.

${ }^{110}$ Sobre este punto remitimos al lector a mi trabajo , "Don Sancho de Castilla (1363-1371): Apuntes biográficos de un hijo ilegítimo de Pedro I", en Mundos medievales: espacios, sociedades y poder. Homenaje al profesor José Ángel García de Cortázar y Ruiz de Aguirre, Santander, 2012, vol. II, pp. 1.1251.135 . 
Catalina de Lancaster, los 10.100 maravedíes en cuenta de su mantenimiento, raciones y quitaciones de la Casa de la reina y destinados a María de Castilla, hija ilegítima de Pedro I, de los 20.000 que en total había recibido de Catalina de Lancaster ${ }^{111}$; idéntica operación se repetiría en octubre de ese mismo año, en esta ocasión para el pago, también en cuenta, de 5.874 maravedíes ${ }^{112}$. Finalmente, el 15 de octubre de 1392, el tesorero de la reina, Sánchez de Villarreal, ordenaba al recaudador Juan Alfonso de Ocaña entregar dichas cantidades, además de otros 1.013 maravedíes más a su beneficiaria ${ }^{113}$.

En otros casos, parece que la orden de pago de raciones de los oficiales adscritos a la Casa de la reina fue dada por la propia soberana. Así, por una carta misiva de 1401, Catalina de Lancaster ordenó a los oficiales mayores de su Casa que pagasen una ración diaria de 12 maravedíes a Teresa Vázquez de Ayala, hija de Pero Suárez, alcalde mayor de Toledo, por el oficio de doncella de la Reina ${ }^{114}$.

TABLA 3

Oficios y oficiales de la despensa de las reinas consortes, príncipe e infantes (1401-1463)

\begin{tabular}{l}
\multicolumn{1}{c}{ OFICIAL } \\
Jácome Vázquez $^{115}$ \\
Juan Sánchez del Castillo ${ }^{116}$ \\
Juan García (¿de Soria?) ${ }^{117}$ \\
Martín López $^{118}$ \\
Alfonso López $^{119}$
\end{tabular}

OFICIO

Despensero

Despensero

Despensero

Despensero

Despensero
PERSONA REAL

Catalina de Lancaster

Catalina de Lancaster

Catalina de Lancaster

Catalina de Lancaster

Catalina de Lancaster
FECHAS

1401

1409

1412

1418

1418

\footnotetext{
111 1392, junio, 18. Segovia. ASDRT, nº 949. Francisco de P. Cañas Gálvez, Colección diplomática de Santo Domingo el Real de Toledo. Documentos reales I. 1249-1473, Madrid, 2010, doc. 34, pp. 77-78. 112 1392, octubre, 15. Segovia. ASDRT, no 25 y 949. Francisco de P. Cañas Gálvez, Colección..., doc. 38, pp. 80-81.

${ }^{113}$ ASDRT, no 949, 47 y 385. Francisco de P. Cañas Gálvez, Colección..., docs. 37, 39 y 40, pp. 80-82. 11415 de septiembre de 1401, septiembre, 15. ASDRT, n 41. Verardo García Rey, "La famosa priora Da Teresa de Ayala (Su correspondencia íntima con los monarcas de su tiempo)", Boletín de la Real Academia de la Historia, XCVI, 1930, doc. n 4, pp. 735-736. Francisco de Paula Cañas Gálvez, Colección..., doc. 60, p. 112.

115 (1401), diciembre, 9. Toledo. AM, Burgos, $\mathrm{SH}^{\circ} 2.881$.

116 AHNNob, Osuna, Leg. 1.837, nº 1.

${ }^{117}$ AM, Valladolid, Caja 2, n 2, publicado por Juan Agapito y Revilla, "Los privilegios de Valladolid", Boletín de la Sociedad Castellana de Excursiones, II (1905-1906), pp. 476-479, n 117-LII, y regestado en Fernando Pino Rebolledo, Inventario de la documentación especial, Valladolid, 1988, doc. 34, pp. 19-20; y RAH, Salazar, M-61, ff. 64r-66r. Citado por Santiago González Sánchez, La Corona de Castilla..., p. 1.207.

${ }^{118}$ Como tal figura en el testamento de la reina. 1418, mayo, 31. Valladolid. Luis Corell Ruiz, Una copia del testamento de Catalina de Lancaster, Valencia, 1952, p. 88.

${ }^{119}$ Así figura en el testamento de la reina. 1418, mayo, 31. Valladolid. L. Corell Ruiz, Una copia..., p. 88.
} 
OFICIAL

García Álvarez de Toledo ${ }^{120}$

Lope Fernández

de Treviño ${ }^{121}$

Diego Alfonso de Molina ${ }^{122}$

Alfonso de Ribera ${ }^{123}$

Rodrigo Álvarez

de Valladolid ${ }^{124}$

Bartolomé Fernández

de Palencia ${ }^{125}$

Alfonso González

de Alcalá ${ }^{126}$

Ferrand Martínez

de Sevilla ${ }^{127}$

Juan de León ${ }^{128}$

Alfonso de Sequera ${ }^{129}$
OFICIO

Despensero mayor

Despensero

Contador

de la despensa

Despensero mayor

PERSONA REAL

María de Aragón

María de Aragón

María de Aragón

Príncipe Enrique

Despensero mayor Infante Juan de Aragón

Lugarteniente del

despensero mayor Infante Juan de Aragón

Infanta Leonor

Despensero

de Aragón

Infante Juan

Despensero mayor

de Aragón,

rey de Navarra

Despensero

Infantes Isabel

y Alfonso

Despensero mayor Juana de Portugal
1444

1440

FECHAS

1427

$1437-1445$

$1414-1415$

1414

1415

$1427-1428$

1462

1463

De igual modo, el incremento de las cantidades destinadas sólo a la despensa regia, sin contar las sumas destinadas a los despenseros mayores de las raciones de la Casa del rey, fue en aumento durante los reinados de Juan I a Enrique IV. Aunque las cifras en este sentido son escasas, las conocidas son significativas de todo cuanto venimos argumentando. La documentación de archivo nos proporciona algunos datos cuanti-

${ }^{120}$ RAH, M-93, f. 97r-v.

${ }^{121}$ Como tal aparece en una escritura de 1437, julio, 16. Tordesillas. AHNNob, Frías, Leg. 126-21 y $\mathrm{AM}^{\mathrm{o}}$, Guadalupe, Leg. 3 (en esta última fuente figura sólo como Lope; suponemos que se trata del mismo Lope Fernández de Treviño).

${ }^{122}$ AGS, MYP, Leg. 1, f. 843; y Leg. 6, f. 54. Para los otros oficios que desempeñó en la corte de Juan II y los arzobispos de Toledo véase Francisco de Paula Cañas Gálvez, Burocracia...., pp. $273-274$.

${ }^{123}$ Pero Carrillo de Huete, Crónica..., pp. 335 y 336.

${ }^{124}$ ACA. Reg. 2.424, ff. 29v-30r y 74v.

${ }^{125}$ ACA. Reg. 2.424, ff. 29v-30r. Posiblemente familiar de Juan Fernández de Palencia, escribano de los privilegios de Juan II (1416-1417). Francisco de Paula Cañas Gálvez, Burocracia..., p. 323.

${ }^{126}$ ACA, Reg. 2.414, f. 74r. Quizá emparentado con Lope González de Alcalá, escribano de cámara de Juan II de Castilla (1453-1454). Francisco de Paula Cañas Gálvez, Burocracia..., p. 361.

${ }^{127}$ Archives Départamentales des Pyrénées-Atlantiques, Pau, E535. Probablemente estuvo emparentado con Bartolomé Martínez de Sevilla, tesorero de Juan II (1407); Juan Martínez de Sevilla, escribano de la notaría mayor de Andalucía (1411) y escribano de cámara y contador de Juan II (1437-1441); y con Diego Martínez de Sevilla, escribano de cámara de Juan II y recaudador mayor de la moneda forera del arzobispado de Sevilla con el de Cádiz (1446). Francisco de Paula Cañas Gálvez, Burocracia...., pp. $334,411,486,489$ y 515 .

${ }^{128}$ Francisco de Paula Cañas Gálvez, “Las casas...”, pp. 153, 203-204.

${ }^{129}$ Francisco de Paula Cañas Gálvez, “Las casas...”, pp. 150, 196-197. 
tativos de interés en este sentido, y así, mientras el despensero mayor de Juan I, Juan Núñez, recibía a finales de 1379 un total de 35.000 maravedíes para "la despensa de nuestra casa", décadas después, en 1429, el despensero de Juan II, Fernando de Torres, percibió para idéntico destino 450.000 para la despensa del rey y en 1465 , la suma destinada a esta despensa era ya de 650.000 maravedíes $^{130}$.

Al igual que los demás miembros de la Casa Real, los despenseros recibían sus correspondientes raciones y quitaciones. Nos son desconocidas hasta tiempos de Alfonso de Trastámara, titulándose ya rey de Castilla y León. Por los registros del Archivo General de Simancas sabemos que el despensero real de este monarca, Alfonso de Almagro, disfrutó desde agosto de 1465, y confirmado en marzo de 1466, de una quitación anual de 5.000 y una ración para tres mozos de ayuda que percibían 10 maravedíes diarios que hacían 3.000 maravedíes para cada mozo al año. En total, 14.000 maravedíes por su trabajo y la ayuda mencionada ${ }^{131}$.

\section{Los despenseros mayores de las raciones de la Casa del Rey (1382-1456)}

Es en este marco de creciente complejidad institucional de la vida áulica en el que debe enmarcarse el nacimiento y primer desarrollo del oficio que ahora estudiamos. El mencionado ascenso de oficiales adscritos a la Casa Real ${ }^{132}$, consecuencia directa de las reformas desarrolladas entonces dentro del marco regio como impulso de consolidación del poder administrativo y representativo de la Corona, exigió la creación de un oficial encargado exclusivamente de la gestión burocrático-administrativa y el pago de las raciones a las que los distintos miembros de la Casa Real y los oficiales áulicos tenían derecho por el desempeño de su trabajo.

Aunque los procuradores reunidos en Valladolid en 1451 aseguraron que “... por que las rraçiones asi se podiesen pagar, fue ordenado que en vuestra casa ouiese despensero de las rraçiones e de las cosas dellas..."133, aludiendo a que el origen de oficio tuvo lugar en tiempos de Juan II, lo cierto es que según los datos que manejamos su aparición debió de tener lugar décadas antes, seguramente a principios de 1380, en los iniciados del reformista reinado de Juan I, recayendo entonces en el mencionado Ferrant Gascón, un oficial áulico que ya había servido como despensero a este monarca desde sus años de infante heredero al trono castellano (1374) ${ }^{134}$. En febrero de 1380 Gascón aparecía como despensero mayor, sin especificarse entonces que lo

130 1380, enero, 8. AHNNob, Osuna, Carp. 40, nº 1. Citado por Francisco de Paula Cañas Gálvez, "La Casa de Juan I...”, p. 155.; y Miguel Ángel Ladero Quesada, La Hacienda ..., pp. 269 y 279.

131 1465, agosto, 6, y 1466, marzo, 30. AGS, QC, Leg. 2, ff. 7 y 9. Dionisia Rodríguez García, Documentación..., docs. 29 y 199 , pp. 11 y 35.

${ }^{132}$ Motivo de queja de los procuradores reunidos en Briviesca en 1387. Cortes, III, pp. 422-427. Citado por Francisco de Paula Cañas Gálvez, "La Casa de Juan I de Castilla...”, p. 140.

${ }^{133}$ Cortes..., III, p. 586.

${ }^{134}$ Todo parece indicar que ya era despensero del infante en esa fecha, ya que aparece refrendando una carta firmada por Don Juan en Valladolid el 14 de julio de 1374, confirmando, a su vez, la concesión de 
fuera de las raciones de la Casa de rey; recibía del camarero Diego López de Estúñiga en ese momento un total de 1.350 maravedíes para dar "... raçiones de tres meses a doña María de Çisneros, a quinse maravedíes cada día..."135. Por entonces, 8.000 eran los maravedíes destinados al pago de las raciones a los oficiales de la Casa del rey, seguramente una cantidad adelantada en concepto de anticipo de cifras seguramente mucho más elevadas ${ }^{136}$. Tan sólo dos meses después, en abril de ese año, el mismo Gascón aparecía ya como despensero mayor de las raciones de la Casa del rey cuando recibió del camarero real Diego López de Estúñiga un total de 9.930 maravedíes “... para dar raçiones de dos meses a veynte ballesteros nuestros de la nuestra nómina que mandamos yr con el dicho Ýñigo Lópes al dicho lugar de Gibraleón e para pagar raçión de un maravedí a frey Iohan Velés, nuestro confesor, e a otro freyre, su conpañero, nueve mill e nueveçientos e treynta maravedíes"137. El oficio, como hemos podido comprobar, alcanzó desde el mismo instante de su aparición la categoría de mayor. Por aquellas fechas, imitando quizá el exitoso modelo curial regio, en el entorno de la corte episcopal burgalesa se documenta ya un despensero de los dineros, con funciones, suponemos, similares a las de los despenseros reales y despenseros de las raciones del rey ${ }^{138}$.

Por su parte, el equivalente aragonés del oficio de despensero mayor de las raciones de la Casa del rey, el escrivà de raçió, estaba operativo en aquel reino desde su creación por Pedro III a finales del siglo XIII ${ }^{139}$.

\subsection{Competencias burocrático-administrativas y marcos legales de actuación. derechos arancelarios}

Como ocurrió con parte significativa de los oficios áulicos castellanos bajomedievales, todo hace pensar que no se dictó, o al menos no se ha conservado, reglamentación alguna sobre las pautas de carácter burocrático-administrativo que debieron seguir los despenseros mayores de las raciones de la Casa del rey hasta, al menos, tiempos de Juan II, momento en el que se regularon los derechos arancelarios que los despenseros de las raciones de la Casa del rey deberían recibir por su come-

Alfonso X dada en Murcia el 13 de enero de 1272, por la que se concedían 10 cahíces de sal al convento de Santo Domingo de Caleruega. Eduardo Martínez, Colección diplomática del real convento de Santo Domingo de Caleruega, Vergara, 1931, doc. CIII, p. 123. Francisco de Paula Cañas Gálvez, "La Casa de Juan I...", pp. 155 y 170.

${ }^{135}$ AHNNob, Osuna, Carp. 40, n 1. Luis Suárez Fernández, Historia ..., II, doc. 181, p. 285.

${ }^{136}$ AHNNob, Osuna, Carp. 40, n 1. Citado por Francisco de P. Cañas Gálvez, "La Casa de Juan I...", p. 155

${ }^{137}$ 1380, abril, 3. AHNNob, Osuna, Carp. 40, nº 1. Luis Suárez Fernández, Historia ..., II, p. 289.

${ }_{138}$ Juan Alfonso, racionero y mayordomo del cabildo burgalés. Su nombramiento como Despensero de los dineros tuvo lugar el 3 de mayo de 1396 en Burgos. AC, Burgos, Reg.

${ }^{139}$ Sobre las competencias y atribuciones de los titulares del escrivà de raçió y sus lugartenientes véase Ordinaçions..., pp. 156-160. 
tido. Sobre ello volveremos más adelante.

Es muy probable que el ejercicio cotidiano de ese oficio con la consiguiente diversidad de situaciones legales y administrativas fuera marcando las pautas de comportamiento institucional hasta alcanzar la madurez operativa durante los años del reinado de Juan II, en los que Juan García de Soria y su hijo Luis García de Morales desempeñaron el oficio, fechas, que en líneas generales, coinciden con la consolidación definitiva de una parte significativa de los oficios áulicos en general y de los nacidos al amparo de las reformas administrativas trastamaristas, en particular.

Desde el mismo instante de su nacimiento como oficio, el papel que sus titulares asumieron fue de relevancia en el marco económico de la Casa Real, pero sujetos siempre a la autoridad suprema del mayordomo mayor y sus lugartenientes ${ }^{140}$. Fernández de Oviedo, cuando trata el oficio de contador mayor de la despensa y raciones de la Casa del príncipe, heredero del de despensero mayor de las raciones, aseguraba que su cometido principal era el de señalar “... los títulos de los ofiçios e libra las raçiones de la despensa que se dan en dineros, e con su auctoridad e libramiento se dan las raçiones ordinarias a los que las tienen de aver por mandado e merçed del prínçipe en su despensa;..."141.

Para realizar su cometido, tanto los despenseros mayores de las raciones de la Casa del rey, como después los contadores mayores de la despensa y raciones, recibían en la "cámara e corte", según costumbre, "los dineros contados" por medio de libranzas y la autorización del rey los fondos necesarios directamente de los recaudadores, contadores mayores, tesoreros territoriales y otros perceptores de las rentas reales en sus respectivos ámbitos territoriales de recaudamiento o "partidos"142, trabajando en estrecha relación institucional con el camarero mayor, los camareros menores o subalternos, el contador mayor de la despensa y raciones de la Casa del rey y los tesoreros reales.

Se trataba de elevadas cantidades de dinero destinado a satisfacer las raciones de los oficiales adscritos a la Casa y Corte del monarca. Estas sumas anuales totales variaron al alza a lo largo de la primera mitad del siglo XV, consecuencia, una vez más, del ya explicado aumento de los oficiales adscritos a la Casa Real. En otros casos, más puntuales, también percibieron por orden real cantidades menores para poder

\footnotetext{
${ }^{140}$ Don Juan Manuel, Libro de los estados..., pp. 289-290.

${ }^{141}$ Gonzalo Fernández de Oviedo, Libro...., p. 87.

${ }^{142}$ Según Ladero Quesada, existían en Castilla recaudadores para las siguientes demarcaciones territoriales-eclesiásticas: arzobispado de Toledo, obispado de Plasencia, "sacadas" de Coria y Cáceres, obispados de Segovia, Salamanca-Ciudad Rodrigo, Palencia, Zamora, León-Astorga, Ávila, Burgos, Calahorra, Cuenca, Sigüenza, Osma, Córdoba, Reino de Galicia, "cuatro sacadas" de Asturias de Oviedo, además de recaudadores especiales para el servicio y montazgo, los servicios de aljamas de judíos y mudéjares, la renta de la cancillería y los derechos de exportación de las "cosas vedadas". Miguel Ángel Ladero Quesada, "Cortes de Castilla y León y fiscalidad regia (1369-1429), en Las Cortes de Castilla y León en la Edad Media, vol. I, Valladolid, 1988, p. 344. Estas y otras demarcaciones territoriales en Francisco de Paula Cañas Gálvez, Burocracia ..., pp. 133-135.
} 
atender pagos puntuales o adelantos en el desembolso total del dinero dirigido al pago de raciones como ocurrió con los tesoreros y recaudadores ya mencionados de $\mathrm{Ca}$ talina de Lancaster.

En enero de 1382, por ejemplo, Juan I ordenaba a las ciudades, villas y lugares que fueron del conde Sancho de Alburquerque que Fernán Rodríguez, recaudador de la condesa Leonor, esposa del citado Sancho, fuera el encargado de pagar la despensa, raciones y mercedes de su Casa, la "retenencia" de sus castillos y casas fuertes ${ }^{143}$. Es muy probable que Rodríguez actuara entonces como recaudador entregando el dinero al despensero mayor de las raciones de la Casa del rey, o bien actuara como lugarteniente del mismo, Ferrant Gascón, y en diciembre de 1392 Enrique III escribía a los alcaldes de Guadalajara comunicándoles el concierto alcanzado con Diego Hurtado de Mendoza, tras su comparecencia junto a Men Rodríguez de Valdés, en relación al impago de las sumas que debía percibir el despensero de las raciones de su casa, Lope Fernández ${ }^{144}$; casi dos años más tarde, en agosto de 1394, este mismo oficial era el encargado de recaudar 5.000 maravedíes que el rey había librado por sus contadores mayores a su despensero mayor, Sancho García, para la despensa de la mesa real ${ }^{145}$.

TABLA 4

Sumas percibidas por los despenseros mayores de las raciones de la Casa del rey (1380-1465)

OFICIAL

CONCEPTO

Ferrant Gascón ${ }^{147}$ Raciones de tres meses a María de Cisneros

SUMAS ${ }^{146}$

FECHA

Ferrant Gascón ${ }^{149}$ ¿Adelanto? raciones para los oficiales de la

1.350

$1380^{148}$

Casa del rey

8.000

$1380^{150}$

Ferrant Gascón Raçiones de dos meses a veynte ballesteros y la raçión de fray Iohan Velés, confesor de rey, y a otro fraile ${ }^{151}$

Juan Sánchez ${ }^{152} \quad$ Sin especificar

9.930

1380

50.000 1397

\footnotetext{
143 1382, enero, 18. Tordesillas. AHN, Clero, Leg. 692, s/f.

144 1392, diciembre 16. Coca. Francisco Layna Serrano, Historia..., pp. 42 y 297.

${ }^{145}$ 1394, agosto, 15. Paredes. am, Tordesillas, en traslado de 1395, abril, 8. Tordesillas. Jonás Castro Toledo, Colección ..., doc. 313, pp. 189-190.

${ }^{146}$ Las cantidades van indicadas en maravedíes.

${ }^{147}$ AHNNob, Osuna, Carp. 40, n 1. Luis Suárez Fernández, Historia ..., II, doc. 181, p. 285.

${ }^{148}$ Hasta abril de 1380 no figura explícitamente como despensero mayor de las raciones de la Casa del rey.

${ }^{149}$ AHNNob, Osuna, Carp. 40, no 1. Citado por Francisco de Paula Cañas Gálvez, "La Casa de Juan I", p. 155

${ }^{150}$ Hasta abril de 1380 no figura explícitamente como despensero mayor de las raciones de la Casa del rey.

151 1380, abril, 3. AHNNob, Osuna, Carp. 40, nº 1. Luis Suárez Fernández, Historia ..., II, p. 289.

${ }^{152}$ AGS, PR, Leg. 29, f. 28.
} 
OFICIAL

Juan Sánchez

(de Salazar) $^{153}$

Juan Sánchez

(de Salazar)

Idem

Idem

Idem

Idem

Idem

Juan García de

Soria

¿Luis García de

Morales?

Luis García de

Morales

Idem
Idem
Idem
Idem

Idem

i?
CONCEPTO

Adelanto de las raciones

Adelanto de las raciones

Adelanto de las raciones

Adelanto de las raciones

Adelanto de las raciones

Raciones de la Casa del rey

Raciones de la Casa del rey

Raciones de la Casa del rey ${ }^{154}$

Raciones de la Casa del rey ${ }^{155}$

Pago "a çiertos mis ofiçiales capellanes e cantores de la mi capilla e reposteros de plata e camas e estrados e coperos e otros mis ofiçiales"156

Raciones y tasas de la Casa del rey ${ }^{157}$

Pago parcial del tercio segundo de las raciones

y tasas de la Casa del rey ${ }^{158}$

Incremento a la cantidad y concepto anterior ${ }^{159}$

Adelanto de la suma de 3.000.000 para pagar a

algunos cazadores del rey

Tercio primero de las raciones de la oficiales de

la Casa del rey ${ }^{161}$

Raciones de la Casa de Enrique IV ${ }^{162}$

La dinámica del trabajo burocrático-admi-

$\begin{array}{cc}\text { SUMAS }^{146} & \text { FECHA } \\ 600 & 1408 \\ & \\ 200 & 1408 \\ 100.000 & 1408 \\ 900.000 & 1409 \\ 200 & 1410 \\ 4.500 .000 & 1409 \\ 4.500 .000 & 1410 \\ & \\ 3.500 .000 & 1429 \\ 918.640 & 1451\end{array}$

$400.000 \quad 1453$

$3.000 .000 \quad 1453$

$575.000 \quad 1453$

$37.000 \quad 1453$

$80.000^{160} \quad 1454$

$700.000 \quad 1454$

$2.000 .000 \quad 1465$

\footnotetext{
${ }^{153}$ Las cantidades referentes a Juan Sánchez (de Salazar) en Biblioteca Colombina. Infanta. 3-7-5. María Victoria Vilaplana, "Un ajuste de cuentas del alcabalero mayor de Sevilla Pedro de Ortiz (1420)", Historia, Instituciones, Documentos, 1, 1974, pp. 445, 451, 459 y 474.

154 ags, dc, Leg. 1, f. 93. Miguel Ángel Ladero Quesada, La Hacienda..., p. 269.

155 "El dicho despensero. Año de iUccccli años. Cámara. Ouo de auer el dicho despensero el dicho año de iUccccli años nueueçientos et dies e ocho mill e seysçientos e quarenta marauedís de cámara para pagar las dichas raçiones et tasas este dicho año segund que en la alualá del rey que su señoría por ello mandó dar". AGS, EMR, Leg. 8, f. 257.

${ }^{156}$ Por albalaes de 1453, julio, 2 y 1453, agosto, 10. AGS, CySR, leg. 42, f. $1 \mathrm{~m}$.

${ }^{157}$ 1453, octubre, 15. AGS, CySR, Leg. 42, f. 1m. 5. Apéndice documental, doc. 8.

158 1453, noviembre, 24. AGS, CySR, Leg. 42, f. 1m. 5. Apéndice documental, doc. 9.

159 1453, diciembre, 3. AGS, CySR, Leg. 42, f. 1m. 5. Apéndice documental, doc. 10.

${ }^{160}$ Esta cantidad procedió del pan, maravedíes, rentas y pechos de Villafrechós durante el tiempo que estuvo secuestrada por orden real. 1454, enero, 22. AGS, CySR, Leg. 42, f. 1m. 5. Apéndice documental, doc. 17.

161 1454, junio, 15. AGS, CySR, leg. 42, f. 1m. 5. Apéndice documental, doc. 43.

${ }^{162}$ AGS, MYP, Leg. 49. Citado por Miguel Ángel Ladero Quesada, La Hacienda ...., p. 279.
} 
nistrativo del despensero mayor de las raciones de la Casa del rey, Luis García de Morales, nos es bien conocida gracias a la documentación conservada en el Archivo General de Simancas. Previa orden del rey, Gonzalo de Alba, repostero de camas de Juan II y recaudador del rey desde años atrás ${ }^{163}$, entregaba a García de Morales la cantidad asignada a estos pagos de raciones y tasas de la Casa Real, es decir, las tasas o derechos arancelarios percibidos por algunos oficiales regios por el desempeño de sus oficios, cantidades fijadas por Enrique II en $1371^{164}$ y $1374^{165}$ y posteriormente por Juan II en 1433 y $1436^{166}$, y cuya gestión llevaba su propia administración burocrática en la despensa ${ }^{167}$.

Lo normal fue que el rey ordenase a los contadores mayores que librasen por mediación de los distintos arrendadores-recaudadores que el despensero mayor de las raciones de la Casa del rey designase ${ }^{168}$, y una vez esa suma en manos del despensero fuera repartida en los tres tercios en los que se dividían los pagos a los oficiales reales, destinándose más tarde las correspondientes cantidades para el pago, habitualmente con retraso de meses ${ }^{169}$, y en ocasiones, si atendemos a la quejas mostradas por los procuradores en las Cortes de Valladolid de 1451, de años ${ }^{170}$, de cada uno de los citados tercios ${ }^{171}$ (abril, agosto y diciembre), posteriormente se extendía la cédula, al-

${ }^{163}$ Años antes ya había desempeñado el oficio de arrendador-recaudador mayor en la merindad Allende Ebro (1447), ello explica sus gestiones cerca de García de Morales; a ello habría que añadir su posición de favorito entre los oficiales curiales del momento al ser uno de los personajes que más se benefició tras la caída de Álvaro de Luna en 1453 al ser nombrado notario mayor de Castilla, oficio que hasta entonces había desempeñado el maestre de Santiago, y dotado con una quitación anual de 12.000 maravedíes. Francisco de Paula Cañas Gálvez, Burocracia ..., pp. 242-243. También Francisco de Paula Cañas Gálvez, "Una conspiración...”, pp. 267-287.

${ }^{164}$ En las Cortes de Toro. Cortes..., II, pp. 217-243.

${ }^{165}$ En las Cortes de Burgos. Cortes..., II, pp. 268-275.

${ }^{166}$ En las ordenanzas de 1433, octubre, 20. Segovia y 1436, diciembre, 15. Guadalajara. BN, Ms. 9.427. Documentos de Juan II, (Edición de Juan Abellán Pérez), Murcia-Cádiz, 1984, doc. nº 180, pp. 428460; y Fernán Pérez de Guzmán, Crónica del serenisimo príncipe don Juan, segundo Rey deste nombre en Castilla y León, Madrid, 1953, pp. 529-532. Sobre las tasas en lo concerniente a los oficios y oficiales de la cancillería real citar Francisco de Paula Cañas Gálvez, Burocracia ..., pp. 50-54, 68-70, 79, 81, 98-109, 146-147, 149-150, 159-160, 162-164, 168-169, 174-176, 177-178, 198-202, 208-209 у 213.

${ }^{167}$ Entre las ya mencionadas escrituras custodiadas en una de las arcas en la cámara del infante Juan en 1421 había “... algunos escriptos de tasas della (de la despensa)”. AHN, Códices, 1.369, f. 74v.

168 “... librádgelos en qualesquier mys recabadadores e arrendadores mayores de los mys regnos señaladamente en los recaudadores e arrendadores quel dicho my despensero vos dixiere e señalare para que ge los ellos libren señaladamente en los lugares e rentas e personas quel dicho my despensero o los que lo ouieren de recabdar para él...". 1453, octubre, 15. AGS, CySR, Leg. 42, f. $1 \mathrm{~m}$.

${ }^{169}$ Por albalá de 1454, febrero, 6 el rey ordenó a Gonzalo de Alba entregar 798 maravedíes a Luis García de Morales para pagar a Guillemýn Menasir, tenor del rey, lo que se le debía en concepto de ración del año 1453. AGS, CySR, leg. 42, f. $1 \mathrm{~m}$.

170 “.... desde quinçe annos a esta parte... los dichos vuestros ofiçiales non son pagados de las dichas sus rraçiones..." mientras otros oficiales "... ha çinco o seis annos e mas tienpo que non han auido cosa alguna de las dichas sus rraçiones...". Cortes..., III, p. 586.

${ }^{171}$ Por ejemplo, albalá del rey de 1453, noviembre, 24, ordenando a Gonzalo de Alba entregar a Luis 
balá o nómina ${ }^{172}$ del rey autorizando la cesión del dinero por parte de Alba a García de Morales para pagar de forma conjunta ${ }^{173} \mathrm{o}$ individualmente a cada uno de los oficiales ${ }^{174}$. Y, por último, el despensero firmaba una cédula en que la se pagaba al beneficiario su correspondiente ración asentándoselos en “... las rentas e personas quel dicho despensero le dixiere" 175 .

La correcta adjudicación de arrendadores-recaudadores en los partidos adecuados era determinante para que la labor de estos despenseros se cumpliera sin contratiempos. La documentación, sin embargo, nos asegura que no siempre fue así. En las Cortes de Valladolid de 1451, por ejemplo, los procuradores protestaron ante el rey alegando que desde hacía años el dinero para pagar la mayor parte de las raciones se libraba “... donde las non pueden cobrar nin cobran..." y por ello, seguían argumentando los procuradores, “... los dichos ofiçiales de vuestra casa non pueden seruir a vuestra alteza nin tienen que comer nin que vestir, e como esto sea grand deseruiçio vuestro e mucho danno e destroyçion de los dichos vuestros ofiçiales" ${ }^{\prime 16}$.

A ello había que añadir los excesos que los tesoreros mayores cometían frecuentemente a la hora de percibir los derechos arancelarios de los libramientos de dinero. A pesar de haber regulado sus tasas y derechos arancelarios en la ordenanza segoviana de octubre de $1433^{177}$, en las mencionadas Cortes vallisoletanas de 1451 los procuradores explicaban el impago de las raciones de algunos oficiales por los abusos co-

García de Morales un total de 575.000 maravedíes para el pago del segundo tercio de las raciones de algunos oficiales reales. AGS, CySR, leg. 42, f. 1m. 5. Apéndice documental, doc. 9.

${ }^{172}$ El modelo cancilleresco-administrativo más frecuente para ordenar estos pagos fue la cédula. Algunos ejemplos en 5. Apéndice documental, docs. 1, 2, 7 y 8 (albaláes), 3, 4, 5 y 10 (cédulas) y 6 (nomina). En ocasiones en un mismo documento se alude a su naturaleza administrativa como cédula o albalá indistintamente; en la cédula de 1454, febrero, 6, leemos: “... este año de la fecha de este mi alualá, e tomad su carta de pago con la qual e con esta mi çédola...”. 5. Apéndice documental, doc. 19.

${ }^{173}$ Este es el caso de los 400.000 maravedíes que en 1453 el rey destinó al pago de ciertos oficiales de la Casa del rey. 1453, julio, 2. 1453, agosto, 10. AGS, CySR, Leg. 42, f. 1m.

${ }^{174}$ Algunos ejemplos en 5 . Apéndice documental, docs. 3 y 4, entre otros muchos más.

175 "Enbió el dicho despensero por su çedula firmada de su nonbre que tyene Alfonso Núñez de Toledo, fecha dies e ocho días de março del año de iUccccliiii años que estos marevedís que al dicho dspensero de ser librados el año pasad de iUccccliii años libren dellos a Lope Martínes de Çaráus, escriuano de cámara del dicho señor rey, veynte mill maravedís, e en librándogelos se otorga por preuillejo dellos como sy al mismo fuesen librados...”. AGS, CySR, Leg. 42, f. $1 \mathrm{~m}$.

${ }^{176}$ Cortes..., III, p. 586.

177 "Contador mayor de las raciones: Otrosí, es mi merçed quel mi contador mayor de las raçiones de la mi casa o su logar teniente lieve de cada çien, dos maravedis de contaduría de lo quel librare, e non lieve cosa alguna de aquello para que diere fe que se ha de librar por los mis contadores mayores, salvo que de aquella fe lieve doçe maravedís. Otrosí, que de asentamiento de albalá de raçión nueva lieve un dia de raçión, e de asentamiento de qualquier testimonio de albalá tanta quantía, segund que de suso se contiene que lo lieven los mis contadores mayores, e quel su oficial non lieve cosa alguna por el libramiento, pues el contador mayor lieva dos maravedís de cada çien de lo que libra por sus libros, e que non sean osados de levar nin lieven más nin allende nin otra cosa alguna por raçón del dicho ofiçio, so las penas por mi suso puestas a los mis contadores mayores e chançiller e mayordomo e notarios e sus logares tenientes". BN, Ms. 9.427, f. 9r. 
metidos por los contadores mayores de la despensa a la hora de percibir sus derechos arancelarios que pasaron de percibir el acostumbrado $2 \%$ de cada libramiento a cobrar esas cantidades "de poco tiempo a esta parte... en dinero contado el dicho su derecho de aquel que saca el tal libramiento e non lo quiere dar sin que luego en dinero contado ge los pague..." por ello, siguen argumentando los procuradores, “... algunos de los dichos vuestros ofiçiales algunas vezes dexan de sacar dichos libramientos por non alcançar para pagar luego el tal derecho" "178. Por ello, el propio contador mayor de la despensa y raciones de la Casa del rey, Diego Romero, tuvo que rendir cuentas antes el rey "... para que muestre e dé rrazon commo lo lieua; e si lo lieua commo non deue, yo mandaré que lo non lieue de aqui adelante" $" 179$.

Sobre este asunto volvieron a insistir los procuradores en las Cortes de Burgos de $1453^{180}$, aunque todo parece indicar que tras las determinación del monarca para que la situación se enderezara y dar orden taxativa a los contadores mayores para que libraran las sumas “... en los mejores logares que ser podiere... segund que en tienpo del dicho sennor Rey don Enrrique e avn despues que vuestra alteza rreyna se acostunbraua librar..."181, la situación se corrigió volviendo a la normalidad, al menos de forma momentánea. Precisamente, contamos con los libramientos incompletos por tercios de numerosos oficiales de la Casa del rey correspondientes a los años 1453 y 1454 como podemos ver en las siguientes tablas:

\section{TABLA 5}

Destino de parte de los 400.000 maravedíes entregados por orden del rey a Luis García de Morales para el pago del tercio primero a ciertos oficiales de la Casa del rey $(\mathbf{1 4 5 3})^{182}$

FECHA

1453, julio, $6^{183}$

1453, julio, $10^{184}$

1453 , julio, $11^{186}$

Idem

Idem

Idem
OFICIALES DEL REY

Lope de Pellarés

Fernando de Madrid

Juan de Ertezuela

Diego Gil

Juan de Córdoba

Lope de Priego
OFICIOS

Portero de cámara

Albéitar

Ballestero de caballo

Idem

Idem

Repostero de camas
TERCIO $\mathbf{1}^{\mathbf{0}}$

1.500

$1.200^{185}$

1.830

1.200

Idem

2.340

\footnotetext{
${ }^{178}$ Cortes..., III, pp. 586-587.

179 Cortes..., III, p. 587.

${ }^{180}$ Cortes..., III, pp. 657-658.

${ }^{181}$ Cortes..., III, pp. 586-587.

${ }^{182}$ Por albalá de 1453, julio, 2. Los distintos libramientos de estas cantidades en AGS, CySR, Leg. 42,

f. $1 \mathrm{~m}$. 5. Apéndice documental, doc. 2.

183 5. Apéndice documental, doc. 3.

184 5. Apéndice documental, doc. 4.

${ }^{185}$ La ración era de 10 maravedíes diarios, 3.600 anuales.

186 5. Apéndice documental, doc.5.
} 


\begin{tabular}{|c|c|c|c|}
\hline FECHA & OFICIALES DEL REY & OFICIOS & TERCIO $\mathbf{1}^{\circ}$ \\
\hline \multirow[t]{2}{*}{1453 , agosto, $10^{187}$} & Álvaro de Mendoza & Donceles & 14.400 \\
\hline & Juan de Monsalve & & \\
\hline Idem & Juan de Preñán & Mozo de alanos & 2.000 \\
\hline Idem & Luis González & Escudero de caballo & 1.200 \\
\hline Idem & de Valladolid & & \\
\hline Idem & María Sánchez & Panadera & 1.960 \\
\hline \multirow[t]{2}{*}{ Idem } & Juan de Mendoza & Cazador & \\
\hline & Juan Bernal & Cocinero & 2.730 \\
\hline \multirow[t]{2}{*}{ Idem } & Rodrigo de Segovia & Repostero de capilla & \\
\hline & Juan Fernández de Carrión & 1 Escudero de caballo & 2.400 \\
\hline Idem & Jaime de Yedra & Capellán & \\
\hline \multirow[t]{2}{*}{ Idem } & Diego de Medina & Mozo de capilla & 2.640 \\
\hline & Alfonso de Cadalso & Calcetero & 1.000 \\
\hline \multirow[t]{5}{*}{ Idem } & Andrés de Toledo & Iluminador & 1.200 \\
\hline & Juan de Ciudad & & \\
\hline & Alfonso Fernández de & & \\
\hline & Santa María & Monteros de caballo & 4.680 \\
\hline & Fernando de Llombrales & & \\
\hline Idem & Martín de la Rúa & Ballestero de maza & 1.300 \\
\hline Idem & Pricón & Trompeta & 2.400 \\
\hline \multirow[t]{2}{*}{ Idem } & Álvaro Fernández & & \\
\hline & Juan de Castro & Organistas & 6.460 \\
\hline Idem & Gómez de Hoyos & Caballerizo mayor & 2.400 \\
\hline \multirow[t]{2}{*}{ Idem } & Alfonso Sánchez & & \\
\hline & de Valladolid & Carnicero & 1.800 \\
\hline \multirow{3}{*}{$\begin{array}{l}\text { Idem } \\
1453 \text {, agosto, } 20^{188}\end{array}$} & Diego de Guadalajara & Mensajero de caballo & $1.806+4$ cornados \\
\hline & Juan García de Narváez & Físico y capellán & \\
\hline & & Chantre de Soria & $2.400^{189}$ \\
\hline 1454 , febrero, $6^{190}$ & Guillemýn Menasir ${ }^{191}$ & Tenor de la Capilla real & 3.420 \\
\hline Idem & Idem & Idem & $798^{192}$ \\
\hline 1454 , febrero, $18^{193}$ & $\begin{array}{l}\text { Juan Martínez } \\
\text { de Villarreal }\end{array}$ & $\begin{array}{l}\text { Capellán y cantor de la } \\
\text { Capilla Real }\end{array}$ & $3.000^{194}$ \\
\hline 1454, marzo, $13^{195}$ & $\begin{array}{l}\text { Hans de Ulm } \\
\text { (Hançe Dolmo) }\end{array}$ & Platero del rey & 3.000 \\
\hline
\end{tabular}

\footnotetext{
${ }^{187}$ Nómina de 10 de agosto de 1453, suma en total: 50.685 maravedíes y 4 cornados. 5. Apéndice documental, doc. 6 .

188 5. Apéndice documental, doc. 7.

${ }^{189}$ Los tres tercios de la ración de Juan García de Narváez pasaron al oficio de las quitaciones.

190 5. Apéndice documental, docs. 19 y 20.

${ }^{191}$ De origen francés.

${ }^{192}$ Que se le debían de su ración de 1453.

${ }^{193}$ 5. Apéndice documental, doc. 25.

${ }^{194}$ La ración diaria por ambos oficios era de 25 maravedíes.

${ }^{195}$ 5. Apéndice documental, doc. 28.
} 
TABLA 6

Destino de parte de los 612.000 maravedíes entregados por orden del rey

a Luis García de Morales para el pago del tercio segundo

a ciertos oficiales de la Casa del rey (1453) ${ }^{196}$

FECHA

1453 , diciembre, $3^{197}$

1453, diciembre, $4^{198}$

1453, diciembre, $11^{199}$

1453 , diciembre, $20^{200}$

1453 , diciembre, $24^{202}$ $1454^{203}$

1453 , febrero, $13^{204}$

1454 , mayo, $23^{205}$

1454, mayo, $28^{206}$
OFICIALES DEL REY

Juan García de Narváez

Juan Fernández de Valladolid

Francisco de Alcalá

Juan de Monsalve

Luis González de Valladolid

Guillemýn Menasir

Toledo

Nuño de Arévalo

Sancha Gómez ${ }^{207}$
OFICIO

Físico, capellán y

chantre de Soria $\quad 2.400$

Copero

Repostero de camas $\quad 1.580$

Maestresala

$7.200^{201}$

Escudero de caballo $\quad 1.443$

Tenor francés de la $\quad 3.400$

Capilla Real

Rey de Armas

2.400

Acemilero mayor $\quad 3.600$

Alfayata

1.800

TABLA 7

Destino de parte de los 650.000 maravedíes entregados por orden del rey a Luis García de Morales para el pago del tercio último a ciertos oficiales de la Casa del rey $(\mathbf{1 4 5 3})^{208}$

\section{FECHA}

1454 , febrero, $12^{209}$

1454 , febrero, $12^{211}$

1454 , febrero, $18^{212}$
OFICIALES DEL REY

Fernando de Sevilla

Álvar Fernández

Juan Martínez de Villarreal
OFICIO

Cantor

Organista

$3.000^{210}$

Capellán y cantor

$3.000^{213}$

196 Ordenado en dos pagos, uno de 575.000 maravedíes y otro complementario de 37.000 . 1453, noviembre, 24 y 1453, diciembre, 3 respectivamente. Los distintos libramientos de estas cantidades en AGS, CySR, Leg. 42, f. $1 \mathrm{~m}$.

197 5. Apéndice documental, doc. 11.

198 5. Apéndice documental, doc. 12.

199 5. Apéndice documental, doc. 13.

200 5. Apéndice documental, doc. 14.

${ }^{201}$ No queda claro si se trata del tercio segundo o de un adelanto de su ración.

202 5. Apéndice documental, doc. 15.

203 5. Apéndice documental, doc. 16.

204 5. Apéndice documental, doc. 23.

205 5. Apéndice documental, doc. 39.

206 5. Apéndice documental, doc. 40.

${ }^{207}$ Librados conjuntamente los dos útimos tercios de 1453.

208 1454, abril, 5. AGS, CySR, Leg. 42, fol. 1m. 5. 5. Apéndice documental, doc. 29.

209 5. Apéndice documental, doc. 21.

${ }^{210}$ La ración era de 15 maravedíes diarios.

211 5. Apéndice documental, doc. 22.

212 5. Apéndice documental, doc. 25.

${ }^{213}$ La ración diaria por ambos oficios era de 25 maravedíes. 
FECHA

1454 , abril, $30^{214}$

1454 , mayo, $3^{215}$

1454 , mayo, $3^{216}$

1454 , mayo, $20^{217}$

1454, mayo, $20^{218}$

1454 , mayo, $28^{219}$

1454 , julio, $17^{221}$
OFICIALES DEL REY

Pedro de Cuéllar

Sancho Martínez de Segovia

Lope González de Alcalá

Francisco de Alcalá

Fernando de Medina

Andinete

Sancha Gómez 220

Maestre Alfonso de Roa
OFICIO

TERCIO 3

Ballestero de caballo

2.760

Escudero de caballo

Escribano de cámara $\quad 1.200$

Repostero de camas $\quad 1.440$

Montero de caballo $\quad 4.320$

Platero

1.800

Alfayata

1.800

Cirujano

TABLA 8

\section{Pago de raciones pendientes de 1453 satisfechas en $1454^{223}$}

FECHA

1454, abril, 9

1454, abril, 9

1454, abril, 9

1454, abril, 9

1454, abril, 9

1454, abril, 15

1454 , mayo, 10

1454, mayo, 10

1454, mayo, 10

1454, mayo, 10

1454 , mayo, 13

1454, mayo, 13

1454, mayo, 14

1454, mayo, 14

1454, mayo, 14

1454 , mayo, $15^{225}$

1454, mayo, 15
OFICIALES DEL REY

Juan de Cervantes

Pedro de Alcocer

Ruy González de Garray

Pero López del Monte

Alfonso de Villacasa

Pedro López de Madrid

Alfonso Pérez de Vivero

Gil de Vivero

Alfonso de Vivero

Francisco de Vivero

Alfonso de Vivero

Juan de Tavera

Pero Cano

Fernando de Castropol

Diego de Ribadeo

Martín de Ávila

Luis de Molina
OFICIO

Guarda

Doncel

Capellán

Escribano de cámara

Doncel

Idem

Capellán

Doncel

Idem

Idem

Idem

Idem

Guarda

Idem

Mensajero de caballo

Secretario de latín y

cronista

Guarda
TERCIO $3^{\circ}$

6.332

4.221

5.272

7.036

5.277

7.036

6.462

7.180

8.975

6.962

7.180

5.385

$4.308^{224}$

5.385

5.385

11.880

$6.462^{226}$

214 5. Apéndice documental, doc. 31.

215 5. Apéndice documental, doc. 32.

216 5. Apéndice documental, doc. 33.

217 5. Apéndice documental, doc. 37.

218 5. Apéndice documental, doc. 38.

219 5. Apéndice documental, doc. 40.

${ }^{220}$ Librados conjuntamente los dos últimos tercios de 1453.

2215 . Apéndice documental, doc. 44.

${ }^{222}$ Se le adeudaba un tercio de su ración correspondiente a 1453, pero no se especifica si era el último.

${ }^{223}$ Todos los albalaes de libramiento en AGS, CySR, Leg. 42, fol. $1 \mathrm{~m}$.

${ }^{224}$ Cantidad correspondiente a tercios de su ración. Cada uno de esos tercios era de 2.308 maravedíes.

225 . Apéndice documental, doc. 35.

${ }^{226}$ Ración completa. Cada uno de los tercios de la ración por este oficio eran 2.308 maravedíes. 
FECHA

1454, mayo, 15

1454, mayo, 15

1454, mayo, 15

1454, mayo, 20

1454, mayo, 21

1454, mayo, 24

1454 , junio, $14^{230}$

1454, julio, 2
OFICIALES DEL REY

Pedro de Alcalá

Pedro de Duero ${ }^{228}$

Pedro de Duero

Martín Sánchez de la Cadena

Juan de Alcalá

Vasco de Vivero

Diego de León

Tomás Bretón
OFICIO

Guarda

Escudero de caballo

Capellán

Escudero de caballo

Guarda

Doncel

Platero

Minador
TERCIO 3o

$6.462^{227}$

4.308

716

4.308

$4.308^{229}$

5.385

6.120

4.308

TABLA 9

Destino de parte de los $\mathbf{7 0 0 . 0 0 0}$ maravedíes entregados por orden del rey a Luis García de Morales para el pago de "çiertas contías de maravedís a la reyna doña María de Aragón” y el tercio primero a ciertos oficiales de la Casa del rey (1454) ${ }^{231}$

\section{FECHA}

1454 , abril, $25^{232}$

Idem

Idem

Idem

1454 , mayo, $3^{233}$

1454 , mayo, $3^{234}$

1454, mayo, 31

1454 , mayo, $3^{236}$

1454, mayo, 31
OFICIALES DEL REY

Pedro de Fox

Cornalis de Alemania

Martín Muñoz del Cardoso

Sancho Barquero

Lope González de Alcalá

Guyllén de Inglaterra

Idem

Iohanes de Alemania

Idem
OFICIO

Ministril de chirimía $\quad 2.000$

Idem Idem

Idem Idem

Idem Idem

Escribano de cámara $\quad 1.200$

Tañedor de arpa $\quad 1.500^{235}$

3.000

Tañedor de los órga- $\quad 1.500^{237}$

nos de la cámara real $\quad 3.000$

\section{TABLA 10}

\section{Pago de los tercios segundo y tercero correspondientes a $1454^{238}$}

FECHA

1454, mayo, $18^{239}$
OFICIALES DEL REY

Guillemýn Menasir
OFICIO

Tenor francés de la capilla Real
TERCIO 2。

3.420

\footnotetext{
${ }^{227}$ Ración completa. Cada uno de los tercios de la ración por este oficio eran 2.308 maravedíes.

${ }^{228}$ Se trata de dos Pedro de Duero distintos.

${ }^{229}$ Parece que estos maravedíes se le adelantaron en cuenta, aunque se le pagó con los 3.000.000 de maravedíes presupuestados en 1453 para el abono de las raciones de los oficiales del rey.

2305 . Apéndice documental, doc. 42.

${ }^{231}$ 1454, junio, 15. AGS, CySR, Leg. 42, fol. $1 \mathrm{~m}$.

232 5. Apéndice documental, doc. 30.

233 5. Apéndice documental, doc. 32.

${ }^{234} 5$. Apéndice documental, docs. 34 y 41.

${ }^{235}$ Dados en cuenta.

2365 . Apéndice documental, docs. 34 y 41.

${ }^{237}$ Dados en cuenta.

${ }^{238}$ Todos los albalaes de libramiento en AGS, CySR, Leg. 42, fol. $1 \mathrm{~m}$.

${ }^{239} 5$. Apéndice documental, doc. 36.
} 
FECHA

OFICIALES DEL REY

OFICIO

TERCIO $2^{\circ} / 3^{\circ}$

1454, julio, 17

Maestre Alfonso de Roa

Cirujano

$7.200^{240}$

TABLA 11

Otras cantidades libradas en concepto de raciones y otros gastos entre 1453-1454 241

FECHA $^{242}$

1453 , octubre, 25

1453 , noviembre, 8

1453, noviembre, 26

1453 , diciembre, 19

Idem

1454, enero, 13

1454, abril, 10

1454, mayo, 7

Idem

Idem

1454, mayo, 11

1454, mayo, 14

Idem
OFICIALES DEL REY

Rodrigo de Villacorta

Diego Romero ${ }^{245}$

Ruy Díaz de Mendoza

Rodrigo Ponce

Gabriel Ponce

Ruy Díaz de Mendoza

Lope (Martínez) de Zarauz

Alonso de Valladolid

Diego de Valladolid

Ferrando de Valladolid

Juan de San Pedro

Juan Alfonso de Valladolid

Juan Rodríguez de Valladolid
OFICIO

RACIÓN

/OTROS $^{243}$

Canciller mayor

$38.160^{244}$

Contador mayor de la

Casa del rey

53.395

Mayordomo mayor

Catarribera

$21.442^{246}$

4.221

Guarda "que sirve

por catarribera"

6.645

Mayordomo mayor $\quad 15.000^{247}$

Escribano de cámara $\quad 13.000$

Doncel

5.277

Escudero de caballo

4.221

Ballestero de caballo

2.814

Alférez

4.308

Guarda

6.462

Guarda

Sin embargo, y tras esta apariencia de tranquilidad institucional en los años finales del reinado de Juan II, tras el fallecimiento del despensero mayor de las raciones de la Casa del rey Luis García de Morales en 1456, el oficio cambió de denominación uniendo las labores del contador de la despensa a las de estos despenseros en un solo titular que bajo la denominación de Contador mayor de la despensa y raciones de la Casa del rey empezó a ser operativo en tiempos de Enrique IV y Alfonso XII como vimos en la tabla número 3. Fernández de Oviedo nos indicar que las competencias de estos contadores mayores de la despensa y raciones eran prácticamente idénticos

\footnotetext{
${ }^{240}$ En esa fecha se ordena el pago de la ración que tenía pendiente de 1453 y los tres tercios de su ración correspondiente a 1454. En total 9.600 maravedíes.

${ }^{241}$ Todos los albalaes de libramiento en AGS, CySR, Leg. 42, fol. $1 \mathrm{~m}$.

${ }^{242} \mathrm{La}$ fecha es la de la cédula del despensero mayor de las raciones de la Casa del rey ordenando el libramiento de dichas cantidades.

${ }^{243}$ Todas las cantidades van consignadas en maravedíes.

244 "En cuenta de su raçión quel del dicho señor rey tiene con el dicho ofiçio e de otros çiertos sus hermanos e criados que en el dicho despensero le han de ser librados".

245 "Por sý e por Juan Romero, su fijo".

246 "De las raçiones de sus fijos".

247 "A los plaseres del rey".
} 
a los que hasta entonces habían desempeñados los despenseros mayores de las raciones de la Casa del rey.

Respecto a las cantidades de dinero que el despensero de las raciones de la Casa del rey, tanto el ordinario como el mayor, pudieran recibir en concepto de raciones y quitaciones nos es completamente desconocido. Sabemos, en cambio, las sumas que desde tiempos de Juan II habrían de percibir por sus derechos arancelarios por la documentación que debían tramitar durante el ejercicio de sus responsabilidades. El primer testimonio conocido, posiblemente el único dictado entonces, de los despenseros ordinarios, aunque no se señala a los mayores, de las raciones de la Casa del rey data, como apuntábamos más arriba, de tiempos de Juan II. Una copia de este documento estaba asentada, según nos indica el propio monarca, "en los libros de los dichos mis mayordomo é contadores". Se trata del albalá de 6 de abril de $1433^{248}$, confirmatorio, a su vez, de una declaración anterior de fecha desconocida, que el rey incluyó en la conocida ordenanza de Segovia de 20 de octubre de 1433 por la que el rey dispuso una serie de medidas encaminadas principalmente a corregir los abusos que en materia de cobros arancelarios solían cometer una buena significativa de los oficiales regios ${ }^{249}$.

Las cantidades anuales estipuladas en concepto de aranceles estipuladas entonces para los despenseros de las raciones de la Casa del rey serían las siguientes ${ }^{250}$ :

\section{TABLA 12}

\section{Aranceles}

CONCEPTO

"De los maravedies quel dicho mi despensero pagare aquí en la mi corte en dinero contado de lo quel é sus facedores trojiere"

"De los maravedis que trojieren los mis recabdadores á la mi cámara en dinero contado para pagar las dichas raciones é tasas, quel dicho despensero pagare é rescibiere"

"De los maravedis quel dicho dispensero librare en sus recabdadores, que de los maravedis que los dichos sus recabdadores pagaren en dinero contado"

"De los maravedis quel dicho despensero librare en los dichos sus recabdadores é ellos libraren en otras personas en quien fueren librados"

\section{DERECHOS}

27 maravedíes al millar

10 maravedíes al millar

20 maravedíes al millar

15 maravedíes al millar

\footnotetext{
248 . Apéndice documental, doc. 1.

${ }^{249}$ Para lo tocante a otros oficios de la corte de Juan II, Francisco de P. Cañas Gálvez, Burocracia..., pp. $39,52,69,70,87,101-102,129,137,146,150-151,160-164,172-173,175,178-179,181,184$, 208 y $212-213$.

${ }^{250}$ La fuente original en BN, Ms. 9.427, f. 9r-v. 5.
} 


\subsection{Los titulares del oficio: perfiles biográficos y trayectorias áulicas}

No son muchos los datos biográficos que hemos podido localizar para trazar las trayectorias curiales de los despenseros de las raciones de la Casa del rey. La mayor cantidad de información, procedente casi toda ella del Archivo General de Simancas, hace alusión a los dos grandes despenseros mayores de las raciones de la Casa del rey en tiempos de Juan II: Juan García de Soria y su hijo Luis García de Morales, los dos oficiales que, como ya hemos expuesto en páginas anteriores, elevaron y consolidaron el oficio entre los grandes cargos burocrático-administrativos de la corte de Juan II de Castilla. Tras la muerte de Luis en 1456, el oficio no llegó a patrimonializarse en ninguno de sus hijos, algo frecuente, como es bien sabido, en muchos de los oficios cortesanos de la época ${ }^{251}$.

\subsubsection{Juan García de Soria (a. de 1397-†1446)}

La andadura profesional de García de Soria ya fue trazada, en sus aspectos más esenciales, en otro trabajo anterior ${ }^{252}$. Junto a los datos aportados entonces, añadimos ahora otros que ayudarán a profundizar más en su trayectoria personal y curial.

Las primeras informaciones que tenemos de este relevante funcionario de la corte real datan del año 1397, fecha en la que por entonces ya se encontraba muy cerca de los estamentos más elevados del poder en Castilla, sobre todo de Catalina de Lancaster, su gran protectora e impulsora en la corte castellana. En junio de ese año aparecía refrendando el testamento de Mencía de Ayala, hermana de la poderosa Teresa de Ayala, priora del Santo Domingo el Real de Toledo ${ }^{253}$, y ostentaba entonces los oficios de escribano de cámara de Enrique III y escribano de cámara y canciller de Catalina de Lancaster ${ }^{254}$. Se trataba de cargos cuyo correcto ejercicio era indispensable para ascender dentro del estricto y muy jerarquizado orden curial Trastámara ${ }^{255}$. Su trayectoria ascendente se vió notablemente reforzada en los años inmediatamente

\footnotetext{
${ }^{251}$ Francisco Tomás y Valiente, "Origen bajomedieval de la patrimonialización de los oficios públicos en Castilla", en Actas del I Symposium de Historia de la Administración, Madrid, Instituto de Estudios Administrativos, 1970, pp. 123-159.

${ }^{252}$ Francisco de Paula Cañas Gálvez, Burocracia ..., pp. 346-347.

${ }^{253}$ Sobre esta relevante religiosa remitimos al lector a los trabajos de Verardo García Rey, "La famosa...", pp. 685-732; y de Francisco de Paula Cañas Gálvez, Colección..., pp. 17-23; y "Urraca Téllez: Ascendencia social y proyección político-religiosa de una priora de Santo Domingo el Real de Toledo (ca. 1352 - †1431-32)”, Mirabilia, 17, 2013/2, pp. 274-276, 291-293, 297-299 у 302.

254 1397, junio 29. Lugar de las iglesias de Santa María de Nieva y de Santa Ana. RAH, Salazar, M-36, ff. 173v-176v. Entre los testigos de la firma figuraban nombres destacados de la corte de la reina: fray Juan de Valladolid, confesor de la reina; Juan Duque, portero mayor; Alfón González, caballerero de la reina; y Fernando de Ribadeo, portero.

${ }^{255}$ Sobre ello los trabajos de Francisco de Paula Cañas Gálvez, Burocracia ..., pp. 83-200 y "El canciller...", pp. 135-153.
} 
posteriores, principalmente durante la minoría de edad de Juan II y la regencia de Catalina de Lancaster, etapa en la que aparecía desempeñando los oficios de escribano de cámara de la reina, su tesorero mayor y regidor de Valladolid, puesto, éste último, que desempeñó desde al menos 1409, hasta su fallecimiento en $1446^{256}$. Es posible que desde aquel año de 1409 fuera ya despensero mayor de las raciones de la Casa del rey en sustitución del anterior titular, Juan Sánchez de Salazar, a quien documentamos ejerciendo tal cargo hasta 1410, momento en el que quizá pudo fallecer ${ }^{257}$.

$\mathrm{Su}$ fortuna económica debió de progresar de forma paralela a la de trayectoria en la corte de Castilla. Sabemos que pudo labrarse un rico patrimonio en Valladolid y sus poblaciones cercanas, villa por entonces centro de la administración regia castellana y sede de algunos de los más poderosos letrados y burócratas de la corte ${ }^{258}$. En 1409 consta que tenía viñas en un lugar llamado "el almasan viejo"; pocos años después, en noviembre de 1412, fecha en la que aparece como despensero de la reina, sabemos que ya había comprado una heredad en Quintanilla de Valdetrigeros a Juan Ramírez de Guzmán ${ }^{259}$, y unos años más tarde, en 1438, adquiría en Boecillo, cerca de Valladolid, unas casas, ocho aranzadas de viñas y cerca de 50 yugadas de tierras de pan llevar por las que abonó 30.000 maravedíes y cuyas rentas se habrían de añadir a las que ya recibía por juros ${ }^{260}$. Disfrutó, asimismo, de 6 excusados por el desempeño de su oficio de escribanía de cámara del rey, que en el momento de su fallecimiento, en 1446, pasaron a repartirse su hijo Luis García de Morales y su yerno, el citado Alfonso de Estúñiga ${ }^{261}$. Todo ello le permitió contar con un nivel de vida alto en el que no faltaron los criados domésticos en su casa. De uno de ellos, Juan de Valladolid, sabemos que recibió de merced real 1.000 maravedíes vitalicios años después, en $1452^{262}$.

$\mathrm{Su}$ fortuna debía de ser lo suficientemente grande como para poder disponer de unas "casas" en Valladolid, en la calle de Teresa Gil, donde vivían algunos de los ofi-

\footnotetext{
${ }^{256}$ Adeline Rucquoi, Valladolid en la Edad Media, Valladolid, 1997, vol. II, p. 73, notas no 168 y 169.

${ }^{257}$ No es mucho lo que sabemos de su descendencia, aunque todo parece indicar que al menos su hijo Lope de Salazar se mantuvo vinculado a los círculos de poder castellanos. En 1409 vendía la casa de Laceñana a Juan de Velasco, camarero del rey; y unos años más tarde, en mayo de 1412, era Leonor de la Vega quien otorgaba escritura de poder para que Lope de Salazar reclamara en nombre de esta dama ante Ruy Gutiérrez de Escalante, vecino de Santander, varios vasallos que le había usurpado. 1409, octubre, 16; y 1412, mayo, 12. RAH, Salazar, M-91, ff. 12v-21r; y M-9, f. 154v, respectivamente.

${ }^{258}$ Sobre este tema Adeline Rucquoi, Valladolid..., vol. II, pp. 21-171; Francisco de Paula Cañas Gálvez, "La itinerancia de la corte de Castilla durante la primera mitad del siglo XV: el eje Burgos-Toledo, escenario burocrático-administrativo y político de la Monarquía en tiempos de Juan II", e-Spania, $\mathrm{n}^{\circ} 8$, 2009 (en línea); y Francisco de Paula Cañas Gálvez, Itinerario de Alfonso XI..., pp. 48-55.

${ }^{259}$ 1412, noviembre, 10. RAH, Salazar, M-61, ff. 64r-66r.

${ }^{260}$ Adeline Rucquoi, Valladolid..., II, p. 221.

${ }^{261}$ AGS, MYP, Leg. 2, f. 428.

${ }^{262}$ Ese año el rey traspasó esa cantidad a Catalina Bonifaz, hija de Juan de Valladolid. 1452, diciembre, 30. Quizá Juan de Valladolid estuviera emparentado con Gonzalo de Valladolid, camarero de Juan II en 1452. Tenía de merced vitalicia desde ese año un total de 7.000 maravedíes. AGS, MYP, Leg. 115, f. 39 .
} 
ciales de la Casa Real ${ }^{263}$, cerca de la Iglesia de San Salvador y colindantes con la huerta del hospital de Todos Santos (en 1455 fue levantada una pared entre esta casa y la huerta), capaces de alojar al propio rey de Castilla. Fue, precisamente, en este palacio, en la llamada "casa grande"264, donde Juan II dictó su testamento el 10 de juio de 1454 y donde falleció pocos días después, el 22 de aquel mismo mes de julio $^{265}$. Parece que fue en este mismo edificio en el que en julio de 1460 se aposentaba el maestre de Alcántara Gómez de Cáceres ${ }^{266}$.

$\mathrm{Su}$ ascenso social parece que fue parejo a su nombramiento como despensero mayor de la raciones de la Casa de Juan II. Por una escritura de marzo de 1419 consta que ya era despensero mayor del rey, pero no se especifica si lo era de las raciones ${ }^{267}$. Una década más tarde sabemos con total certeza que ya ejercía el oficio de despensero mayor de las raciones de la Casa del rey; para ello, se le entregaron de 3.500 .000 maravedíes destinados a la paga de las raciones de oficiales de Juan II $^{268}$. Para el desempeño de su labor contó con la ayuda del mozo escribano Fernán Alfonso de Robles ${ }^{269}$, un oficial cuya trayectoria curial ascendente se debió en buena medida, como así había ocurrido con García de Soria, a la protección que le dispensó Catalina de Lancaster $^{270}$. Por aquellas mismas fechas, o quizá antes, ocupo el principal oficio de la "Universidad de la Tierra de Soria", el de fiel de la Tierra, también de Soria, ciudad perteneciente al patrimonio de la reina de Castilla ${ }^{271}$.

Las preocupaciones de García de Soria y su esposa, Teresa García, por situarse ellos o su descendencia, en las esferas aristocráticas castellanas se documentan de forma temprana en su biografía. Su fortuna patrimonial, unida a la relevancia de los

\footnotetext{
${ }^{263}$ Allí tenían posesiones en 1459 Gonzalo Fernández de Toro, aposentador del rey, y Alfonso de Valladolid, nieto de Diego Sánchez de Valladolid, contador también del rey. 1459, junio, 6. Valladolid. AHN, Diversos-Colecciones, Leg. 212, $\mathrm{n}^{\circ} 166$.

${ }^{264}$ Como tal figura en escritura de 1473, agosto, 24. Valladolid, AHN, Diversos-Colecciones, Leg. 212, $\mathrm{n}^{\mathrm{o}} 163$.

${ }^{265}$ bn. Ms. 10.662, f. 136. Citado por Adeline Rucquoi, Valladolid..., II, p. 73.

${ }^{266}$ Francisco de Paula Cañas Gálvez, El itinerario..., p. 109.

${ }^{267}$ 1419, marzo, 7. RAH, Salazar, M-61, ff. 62v-64r.

268 ags, dc, Leg. 1, f. 93. Miguel Ángel Ladero Quesada, La Hacienda..., p. 269.

${ }^{269}$ Datos biográficos en C. Espejo, "El leonés Fernand Alfonso de Robles, contador mayor de Juan II", Boletín de la sociedad Castellonense de Excursiones, III, 1907-1908, pp. 170-184; María del Carmen Carlé, "Caminos del ascenso en la Castilla Bajo Medieval", Cuadernos de Historia de España, LXVLXVI, 1981, pp. 207-276; y Francisco de Paula Cañas Gálvez, Burocracia ..., pp. 274-275.

${ }^{270}$ Pérez de Guzmán nos retrató una semblanza muy negativa de Alfonso de Robles al asegurar que era: "Ombre escuro e de baxo linaje... inclinado a aspereza e maliçia más que a nobleza nin dulçura de condiçión... fue muy osado e presuntuoso a mandar, que es propio viçio de los baxos omes quando alcançan estado que non se saben tener dentro de límites e términos". Fernán Pérez de Guzmán, Generaciones y semblanzas (Edición de José Antonio Barrio), Madrid, Cátedra, 1998, p. 155.

${ }^{271}$ Máximo Diago Hernando, "Una institución de representación política del campesinado en la Castilla bajomedieval: las 'Universidades de Tierra'”, Historia. Instituciones. Documentos, 23, 1996, p. 301; y "Soria y su Tierra como señorío de miembros de la Familia Real Castellana. Siglos XIV-XVI", Celtiberia, año LVII, $\mathrm{n}^{\circ} 101,2007$, p. 54.
} 
puestos curiales que desempeñó y sus buenas relaciones que mantuvo con la realeza, le facilitaron, sin duda, la labor. En la plenitud de su vida, fue miembro de la Cofradía de Todos los Santos, una de las tres cofradías, en opinión de Rucquoi, de la élite urbana vallisoletana, de la que llegaría a ser mayordomo entre la fiesta de 1437 y la de 1438, aunque, al parecer designó a otro cofrade para ejercer tal oficio, Alfonso Fernández de Vertavillo ${ }^{272}$.

También pudo conseguir matrimonios muy ventajosos para sus dos hijas: Beatriz y Catalina de Soria. La primera de ellas, casó en 1419 con Alfón de Zúñiga, miembro, como es bien sabido, de una importante familia de la nobleza castellana ${ }^{273}$; mientras que Catalina, además de ser objeto por parte del rey de una merced vitalicia de 5.500 maravedíes y 10 cargas de trigo en $1453^{274}$, pudo también contraer un matrimonio muy ventajoso con Pedro de Solís, miembro relevante del patriciado urbano de Salamanca ${ }^{275}$. Otra de sus hijas, María, se casó con Pedro de Tapia, vecino de la ciudad de Segovia, heredando a la muerte de su padre un corral con cuatro casas situadas en la mencionada calle de Teresa Gil, en Valladolid, propiedades que más tarde vendió a Gonzalo Fernández de Toro, contador de Enrique IV, no sin la protesta de Aldonza de Guzmán, viuda de Luis García de Morales, quien se opuso enérgicamente a que esa propiedad pasase a otras manos que no fueran las de su hijo Juan ${ }^{276}$.

No es seguro, aunque sí probable, que fuera también padre de Bartolomé García de Soria, oficial vinculado a la Casa de la reina Isabel de Portugal como encargado de reclamar a los procuradores sorianos el pago de las rentas de las alcabalas de aquel partido (1466-1467) ${ }^{277}$.

Juan falleció en octubre $1446^{278}$. Su hijo, Luis García de Morales, heredó el regimiento de Valladolid y el oficio de despensero mayor de las raciones de la Casa del

\footnotetext{
272 Adeline Rucquoi, Valladolid..., II, p. 74.

${ }^{273}$ De entre la amplia bibliografía relativa a los Zúñiga citamos de modo orientativo y más centrada en los aspectos institucionales las siguientes publicaciones: María Luisa Villalobos y Martínez-Pontrémuli, "Los Estúñiga: la penetración de Castilla de un linaje de la nobleza nueva", Cuadernos de Historia 35, Extra 6, 1975, pp. 327-356; Miguel Ángel Ladero Quesada, "Los señores de Gibraleón”, Cuadernos de Historia VII, 1977, pp. 33-95; Gloria Lora Serrano, "Nobleza y monarquía bajo los primeros Trastámaras: el ascenso de Diego López de Estúñiga", Ifigea 3-4, 1986-1987, pp. 73-108; también de esta misma autora "Los constructores del Palacio de Altamira. La familia señorial de los Estúñigas", en La restauración del palacio de Altamira, Sevilla, 2005, pp. 126-179; Pedro Manuel Cátedra, La historia de la Casa de Zúñiga, atribuida a Mosén Diego de Valera, Salamanca, 2003; y Francisco de Paula Cañas Gálvez, "El libro de la cámara del conde, mi señor: una fuente para el estudio del lujo en la corte de los condes de Plasencia a mediados del siglo XV (1453-1455)", Historia, Instituciones, Documentos, XLI, 2014, pp. 99-145, publicación, esta última, en la que se recoge una amplia bibliografía de carácter más exhaustivo sobre esta familia.

${ }^{274}$ AGS, MYP, Leg. 62, f. 155.

${ }^{275}$ Adeline Rucquoi, Valladolid..., II, p. 74.

${ }^{276}$ Escrituras de1459, junio, 6. Valladolid. ahn, Diversos-Colecciones, Leg. 212, $\mathrm{n}^{\text {os }} 85$ y 166.

${ }^{277}$ Como tal figura en sendas cédulas de la reina solicitando esas cantidades. 1466, abril, 28. Arévalo; y 1467, mayo, 23. Madrigal. AGS, PR, Leg. 49, ff. 32 y 33, respectivamente.

${ }^{278} \mathrm{Su}$ hijo Luis pidió en noviembre la herencia paterna. Citado por A. Rucquoi, Valladolid..., II, p. 73.
} 
rey ${ }^{279}$. Un año más tarde, en diciembre de 1447, la Cofradía de Todos Santos dispuso celebrar las exequias de año y la liturgia habitual por el descanso eterno de García de Soria y su esposa Teresa García ${ }^{280}$.

\subsubsection{Luis García de Morales (¿?-†1456)}

La trayectoria vital y curial de García de Morales es mucho menos conocida que la de su padre, quizá porque quedó ocultada tras los brillos de su progenitor y quizá, también, por los apenas 10 años en los que desempeñó el oficio de despensero en la corte de Castilla.

Es muy probable, aunque no tenemos documentación que lo confirme, que en 1446, tras el fallecimiento de su padre, García de Morales comenzase a ejercer el regimiento de Valladolid y quizá, también el oficio de tesorero del rey ${ }^{281}$. Sin embargo, las primeras informaciones documentadas que tenemos de nuestro biografiado son más tardías, concretamente de 1453, en el contexto de la detención, juicio y posterior ejecución de Álvaro de Luna. La crónica de Chacón asegura que García de Morales, junto a nombres tan notables como los de Alfonso Pérez de Vivero, contador mayor del rey; Alfonso de Estúñiga, guarda mayor del rey; Fernando de Estúñiga; Alfonso Niño, merino mayor de Valladolid; Gutierre de Robles, señor de Valdetrigueros y Rebollar; y Álvaro de Herrera, señor de la Casa de Pina, “... allende de otros muchos... " era uno de los principales y "mayores caballeros que vivían en Valladolid", en el partido favorable al condestable ${ }^{282}$. Su pertenencia a las élites urbanas la confirma también Gil González Dávila en una mención incluida en el Cronicón de Valladolid cuando afirmaba que era uno de los "hijos ilustres" de la villa del Esgueva ${ }^{283}$.

En 1453 sucedió en el cargo de mayordomo de la influyente cofradía vallisoletana de Todos los Santos ${ }^{284}$, también recibió, junto a su cuñado, Alfonso de Estúñiga, los citados 6 excusados que por el desempeño del oficio de escribanía de cámara había disfrutado su padre en vida ${ }^{285}$, además de 10.000 maravedíes vitalicios por orden del $\mathrm{rey}^{286}$, y es, asimismo, el año en el que por vez primera le documentamos desempeñando su oficio de despensero mayor de las raciones de la Casa del rey o despensero

\footnotetext{
${ }^{279}$ AGS, MYP, Leg. 2, fol. 428.

${ }^{280}$ Adeline Rucquoi, Valladolid..., II, p. 74.

${ }^{281}$ Antolínez de Burgos en su Historia inédita de Valladolid (Lib. 2. cap. 24) hace mención de un tesorero de este Rey, llamado Luis de Morales, probablemente nuestro biografiado. Citado en Cronicón de Valladolid, ilustrado con notas por D. Pedro Sáinz de Baranda, en Documentos Inéditos para la Historia de España, vol. XIII, Madrid, 1848, pp. 30-31.

${ }^{282}$ Gonzalo Chacón, Crónica de Don Álvaro de Luna, condestable de Castilla, maestre de Santiago (Edición de Juan de Mata Carriazo), Madrid, 1940, pp. 447-448.

${ }^{283}$ Cronicón..., pp. 30-31.

${ }^{284}$ Adeline Rucquoi, Valladolid..., II, p. 73.

${ }^{285}$ AGS, MYP, Leg. 2, f. 428.

${ }^{286}$ AGS, MYP, Leg. 62, f. 131.
} 
mayor de las raciones y tasas de la Casa del rey ${ }^{287}$, indistintamente. Tiempo antes, hacía 1450, el monasterio de San Francisco de Valladolid le cedía la capilla de San Antonio o de la Concepción de la Vega, donde tras su fallecimiento, ocurrido el 20 de agosto de $1456^{288}$, fue sepultado ${ }^{289}$.

Quizá el momento culminante de la trayectoria curial de Luis tuvo lugar en julio de 1454, cuando Juan II, enfermo ya de muerte, se aposentó en los mencionados palacios, la llamada "casa grande" 290 , que García de Morarles tenía en Valladolid, en la calle de Teresa Gil. Allí, el 10 de julio de 1454, “... en una cama dentro en una cámara de los sus palacios donde su altesa posa que son de Luis Garcia de Morales, su despensero", firmaba su codicilo el rey; no consta, sin embargo, que la firma del testamento real, otorgado tan sólo dos días antes, el 8 de julio, tuviera lugar en el mismo palacio ${ }^{291}$.

En el momento de su fallecimiento, sabemos que estaba casado con la ya mencionada Aldonza de Guzmán, con quien había tenido a sus hijos Juan de Morales, Luis de Morales (o también de Guzmán), Inés y Teresa ${ }^{292}$. Aldonza todavía vivía en agosto de 1473, fecha en la que alcanzó una acuerdo con sus dos hijos varones por el cual se repartirían una parte de la herencia paterna. Así, Luis recibiría una tercera parte de la renta de las aceñas de ventosilla, en el río Pisuerga, en el término de Valladolid, o en su defecto un total de 40.000 maravedíes, quedando entonces la dicha renta vacante y que pasase a manos de Juan de Morales. Luis también recibiría la "casa pequeña" situada en la calle Teresa Gil, "que está junta con la casa grande" que había levantado Juan García de Soria y donde murió Juan II en 1454; no se le entregaría, en cambio, la torre "con el portal donde estála puerta de la dicha casa" aunque a cambio percibiría un "entresuelo que es de la dicha casa grande con vnos graneros que ende están juntos"; todo ello con la condición de no venderlo ni enajenarlo ni traspasarlo a persona alguna. Juan de Morales, por su parte, se quedaría con las llamadas "casas grandes" o "principales", pero con la condición inquebrantable de que ambas casas, las grandes y las pequeñas, en el caso de venderlas se harían de manera conjunta "por lo que valiesen". Finalmente, Aldonza, que aprobó este acuerdo alcanzado con sus hijos, recibió un total de 20.000 maravedíes que le serían entregados en dos pagos de 10.000 maravedíes $^{293}$.

Sabemos que Juan de Morales llegó a desempeñar el oficio de regidor de Valladolid, un cargo que pertenecía por derecho al linaje Tovar con quien Juan había em-

\footnotetext{
${ }^{287}$ Así aparece en la cédula de 1453, diciembre, 11. AGS, CySR, leg. 42, f. 1m. 5. Apéndice documental, doc. 13.

288 "Murió Luis García de Morales, Regidor de Valladolid, viernes xx de agosto de meccclvj”. Cronicón..., p. 35.

${ }^{289}$ Adeline Rucquoi, Valladolid..., II, p. 297.

${ }^{290}$ AHN, Diversos-Colecciones, Leg. 212, no 163.

${ }^{291}$ Memorias..., pp. 124-125.

${ }^{292}$ AHN, Diversos-Colecciones, Leg. 212, no 85 y 166.

${ }^{293}$ 1473, agosto, 24. Valladolid. AHN, Diversos-Colecciones, Leg. 212, nº 163.
} 
parentado ${ }^{294}$. Otro de sus descendientes, Alonso de Morales, se convertiría años más tarde en tesorero de ingresos extraordinarios de los Reyes Católicos ${ }^{295}$. Por su parte, un tal Rodrigo de Morales, emparentado seguramente con Luis y Juan, fue tesorero real y alcalde de Valladolid ${ }^{296}$.

El oficio de despensero mayor de las raciones de la Casa del rey, como apuntábamos más arriba, no parece haberse patrimonializado tras la muerte de Luis y ninguno de sus herederos los ostentó entonces, quedando vacante, quizá por razones que jamás sabremos, hasta tiempos de los Reyes Católicos, cuando, en contextos bien distintos a los de sus antiguos titulares, Francisco Ramírez de Madrid y su hijo, Ferrand, lo volvieron a desempeñar con plena solvencia operativa.

\section{Conclusión}

La despensa regia fue una instancia institucional, económica y administrativa de especial importancia en el desarrollo de la vida de las cortes reales, señoriales y episcopales medievales.

Tras un largo proceso de formación y consolidación que se habría de prolongar entre los siglos XII y XV, a finales del XIV, en plena fase reformadora y modernizadora de las instituciones regias castellanas impulsada por los Trastámara, el nuevo oficio de despensero mayor de las raciones de la Casa del rey se segregó de la despensa de la Casa Real formando todo un entramado burocrático de gran complejidad técnica que fue consolidándose durante la primera mitad del siglo XV. Oficio exigente por cuanto el pago de los servicios prestados a la Corona por los oficiales regios dependía en buena medida de la gestión de estos oficiales, su existencia ha pasado prácticamente inadvertida por todos los estudiosos de las instituciones medievales españolas.

Como tantos otros oficios curiales del bajomedievo, la madurez administrativa de la despensa mayor de las raciones de la Casa del rey, vino de la mano de algunos de sus titulares, en este caso de Juan García de Soria y su hijo Luis García de Morales, cuya trayectoria áulica, estudiada en la medida que nos permite la documentación conservada, resulta indispensable no sólo para conocer su andadura vital, los pormenores de oficio o las relaciones profesionales y clientelares con otros oficiales de la corte, también, porque en el desarrollo de su trabajo hemos podido ampliar la nómina de muchos de los servidores regios a los que tuvieron que librar sus correspondientes raciones y tasas, bien detallados en las amplias tablas que ilustran este trabajo, adentrándonos así en el mundo áulico de tiempos de Juan II y en los distintos caminos del ascenso social y curial en la Castilla trastámara.

\footnotetext{
${ }^{294}$ Adeline Rucquoi, Valladolid..., II, p. 74.

${ }^{295}$ Miguel Ángel Ladero Quesada, La Hacienda..., pp. 44-45; y Rosana de Andrés Díaz, El último..., pp. 1-308.

${ }^{296}$ Adeline Rucquoi, Valladolid..., II, p. 74.
} 


\section{APÉNDICE DOCUMENTAL}

1433, abril, 6 .

Albalá confirmatorio de Juan II de uno anterior suyo por el que se fijan los aranceles que los despenseros de las raciones de la Casa del rey deben llevar por el desempeño de su oficio.

(Inserto en la Ordenanza de 1433, octubre, 20. Segovia)

BN, Ms. 9.427.

J. ABELLÁN PÉREZ, Documentos..., doc. nº 180, pp. 428-460.

Despensero de las raciones de la mi Casa

Es mi merced quel mi despensero mayor de las raciones de la mi casa sea tenudo de guardar é guarde en razon de su oficio la ordenanza por mí fecha que está sentada en los libros de los dichos mis mayordomo é contadores, su tenor de la qual es este que se sigue:

Yo el rey.

Fago saber á vos, el mi mayordomo é contador de la mi despensa é raciones de la mi casa, que yo fice una declaracion, la qual firmé de mi nombre é de la qual su tenor es este:

Ordeno é mando que daquí adelante el mi despensero mayor de las raciones de la mi casa aya é lieve de sus derechos de los maravedis que yo mandare librar en cada año para pagar las raciones é tasas de la dicha mi casa, los maravedis que adelante dira: de los maravedies quel dicho mi despensero pagare aquí en la mi corte en dinero contado de lo quel é sus facedores trojiere, que lieve veinte é siete maravedis del millar é de los maravedis que trojieren los mis recabdadores á la mi cámara en dinero contado para pagar las dichas raciones é tasas, quel dicho despensero pagare é rescibiere, que lieve el dicho despensero diez maravedis al millar, de los maravedis quel dicho dispensero librare en sus recabdadores, que de los maravedis que los dichos sus recabdadores pagaren en dinero contado, que lieven veinte maravedis al millar, é de los maravedis quel dicho despensero librare en los dichos sus recabdadores é ellos libraren en otras personas en quien fueren librados, que lieven quince maravedis al millar.

E quanto toca á lo pasado por algunas razones que á ello me mueven mi merced es que pase como estaba, é le non sea demandada otra razon alguna.

Yo el Rey.

Por que vos mando que lo pongais é asenteis así en los mis libros é nóminas, é lo guardedes é complades é fagades guardar é complir todo é cada cosa dello, segund que de suso se contiene que yo lo declaré e mandé, é así lo declaro é mando agora, é non fagades ende al.

Fecho seis días de abril, año del nascimiento de nuestro señor Jesucrito de mil é quatroçientos e treinta é tres años.

Yo el Rey.

Yo el doctor Fernando Díaz, \&. Registrada.

2

1453, julio, 2.

Albalá de Juan II en el que ordena a Gonzalo de Alba, su repostero de camas, entregar al despensero mayor de las raciones, Luis García de Morales, un total de 400.000 maravedies para pagar a ciertos oficiales de la Casa del rey.

AGS, CysR, leg. 42, f. $1 \mathrm{~m}$.

Luys Garçía de Morales, despensero mayor de la despensa e raçiones de la casa del rey.

Mostró un alualá del rey nuestro señor firmada ( $\mathrm{sic}$ ) de su nonbre fecho en esta guisa:

Yo el rey mando a vos Gonçalo de Alba, mi repostero de camas, que de qualesquier maravedís doblas e florines que vos por mi mandado avedes reçebido e reçebiéredes en qualquier manera para los 
tener aquí en la mi corte para las cosas conplideras a mi seruiçio dedes luego a Luys Garçía de Morales, mi despensero mayor de las raçiones de la mi casa, quatroçientos mill maravedís que es mi merçed que los reçiba de vos para pagar a çiertos mis ofiçiales capellanes e cantores de la mi capilla e reposteros de plata e camas e estrados e coperos e otros mis ofiçiales de la mi casa que continuamente me siruen de sus ofiçios el terçio de sus raçiones que de mi tienen e han de aver este presente año de la fecha de este mi alualá, e tomad su carta de pago del dicho Luys Garçía con la qual e con este mi alualá mando que vos sean reçebidas en cuenta las dichas quatroçientas mill maravedís e otrosy por este dicho mi alualá mando a los mis contadores mayores que de los que este dicho año mandare librar e han de ser librados al dicho Luys Garçía, mi despensero, para las raçiones de la mi casa de los dichos mis ofiçiales de la mi casa de los dichos mis ofiçiales e de otros mis ofiçiales de ella se descuenten las dichas quatroçientas mill maravedís, e non fagades ni fagan ende al.

Fecho dos días de jullio año del nasçimiento del nuestro señor Ihesu Christo de mill e quatroçientos e çinquenta e tres años.

Yo el rey.

Yo Diego Romero la fis escreuir por mandado de nuestro señor el rey.

Registrada.

Fue sobrescripta en las espaldas de la dicha alualá por el dicho Gonçalo de Alua que lo vea e cunpla segund en él se contiene.

(Al margen, a la derecha: cccu)

1453, julio, 6.

Cédula de Juan II ordenado a Gonzalo de Alba, repostero de camas del rey, librar 1.500 maravedies a Luys García de Morales, despensero mayor de las raciones de la Casa del rey, para el pago de la ración que por el oficio de portero de cámara tenía Lope de Pellares.

AGS, CysR, leg. 42 , f. $1 \mathrm{~m}$.

El rey.

Gonçalo de Alua, mi repostero de camas, yo vos mando que de más de los quatroçientos e veynte mill marauedís que vos por my mandado distes a Luys Garçía de Morales, my despensero mayor de las raçiones de la my casa del ofiçio de sus raçiones este presente año o de otros qualesquier marauedís que de más de aquellos por my mandado le avedes dado, le dedes e paguedes luego mill e quinientos marauedís para pagar la raçión que de my tiene Lope de Pellarés, my portero de cámara, para quel ge los de e pague, e tomad su carta de pago con la qual e con esta my çédula le mando que vos sean resçibidos en cuenta los dichos mill e quinientos marauedís, e non fagades ende al.

Fecho seys días de jullio año de çinquenta e tres.

Yo el rey.

Por mandado del rey, Bartolomé Sánches.

E en las espaldas de la dicha çédula fue escripto para el dicho Gonçalo de Alua que la vea e cunpla segund se en ella contiene.

(Al margen, a la derecha: iUd marauedís)

1453, julio, 10.

Cédula de Juan II de Castilla ordenando a Gonzalo de Alua, su repostero de camas, pagar a Fernando de Madrid 1.200 del tercio de su ración por el oficio de albéitar del rey.

AGS, CysR, leg. 42, f. $1 \mathrm{~m}$.

Los marauedís que Gonçalo de Alua, repostero de camas del rey dio e pagó por çédulas del dicho señor rey a çiertos ofiçiales del terçio de sus raçiones deste dicho año. 
El rey.

Gonçalo de Alua, my repostero de camas, yo vos mando que de más de las quatroçientas e catorçe mill e quatroçientos marauedís que vos por my mandado distes a Luys Garçía de Morales, despensero mayor de las raçiones de la my casa, para pagar çiertos mys ofiçiales de la my casa del terçio de sus raçiones deste presente año o de otros qualesquier marauedís que de más de aquellos por my mandado avedes dado, dedes e paguedes luego a Ferrando de Madrid, my albeýtar, mill e dosientos marauedís del terçio de su raçión que de my tenía, e tomad su carta de pago con la qual e con esta my çédula mando que vos sean reçebidos en cuenta, e non fagades ende al.

Fecho dies días de jullio año del nasçimiento del nuestro señor Ihesu Christo de mill e quatroçientos e çinquenta e tres años.

Yo el rey.

Por mandado del rey, Bartolomé Sánches.

Paresçe por fe del mayordomo e contador que tiene Bartolomé Sánches de Badajos fecha a iiii de agosto del dicho año de iUccccliii años en como el dicho Ferrand Garçía (sic) ${ }^{297}$ tenya en raçión del dicho señor rey con el dicho ofiçio iiiUdc marauedís el año a rasón de x marauedís cada dia. Pero Rodrigues. Alonso Garçía.

Et en las espaldas de la dicha çédula fue escripto esto que se sigue:

Gonçalo de Alua, repostero de camas del rey nuestro señor, desta otra parte contenydo ved esta çédula del dicho señor rey desta otra parte escripta e conplid la en todo e por todo segund su señoría por ella vos lo enbia mandar. Leuóla el mismo.

(Al margen, a la izquierda: Cámara. El dicho despensero)

(Al margen, a la derecha: iUcc marauedís)

1453, julio, 11.

Cédula de Juan II ordenando a Gonzalo de Alba, su repostero de camas, librar a Luis García de Morales, despensero mayor de las raciones de la Casa del rey, 6.570 maravedís para el pago del tercio de las raciones a Juan de Ertezuela (1.830), Diego Gil (1.200) y Juan de Córdoba (1.200), ballesteros de caballo del rey, y a Lope de Priego (2.340), repostero de camas, por el desempeño de sus oficios.

AGS, CysR, leg. 42, f. $1 \mathrm{~m}$.

El rey.

Gonçalo de Alua, my repostero de camas, yo vos mando que de mas de las quatroçientas e veynte mill marauedís que por my mandado dystes a Luys Garçía de Morales, my despensero mayor de las raçiones de la my cada para pagar el terçio de sus raçiones a algunos ofiçiales de la my casa este presente año o de mas de otros qualesquier marauedís que por my mandado para ello le auedes dado, le dedes e paguedes luego mill e ochoçientos e treynta marauedís para pagar el terçio de su raçión a Juan de Ertezuela, my vallestero de cauallo, et mill e dozientos marauedís para pagar a Diego Gil, my vallestero de cauallo, et otros myll e dozientos marauedís para pagar el terçio a Juan de Cordoua, my vallestero de cauallo, e doss mill e trezientos e quarenta marauedís marauedís para pagar a Lope de Pliego, my repostero de camas, el dicho terçio, que son todos seys mill e quinientos e setenta marauedís, et tomad sus cartas de pago con las quales e con esta my çédula mando que vos sean reçebidos en cuenta, e non fagades ende al.

Fecho onze días de jullio año de çinquenta e tres años.

Yo el rey.

Por mandado del rey, relator.

Fue sobrescripta en las espaldas de la çédula para el dicho Gonçalo de Alua que lo vea e cunpla. (Al margen, a la derecha: viUdlxx)

${ }^{297}$ Suponemos que debería decir Ferrando de Madrid. 
1453, agosto, 10.

Nómina de Juan II por la que ordena a sus contadores mayores de cuentas recibir en cuenta los 400.000 maravedies que por su orden, Gonzalo de Alba, repostero de camas del rey, entregó a Luis García de Morales, despensero mayor de las raciones de la Casa de Juan II, para pagar el tercio primero de las raciones a ciertos oficiales de rey.

AGS, CysR, leg. 42, f. $1 \mathrm{~m}$.

Yo el rey mando a vos los mis contadores mayores de las mis cuentas que resçibades e pasedes en cuenta a Gonçalo de Alua, mi repostero de camas, los maravedís que de yuso serán contenidos por quanto los dio e pagó por mi mandado a Luys Garçía de Morales, my despensero de las raçiones e tasas de la mi Casa, de más de las quatroçientas mill maravedís que el por mi mandado dio e pagó al dicho Luys Garçía de Morales para pagar a çiertos mis ofiçiales el terçio primero de sus raçiones que de mi tiene e ouieron de aver este presente año de la fecha de esta mi nómyna e por el dicho Luys Garçía de Morales dio e pagó el dicho Gonçalo de Alua los dichos maravedís a las personas que aquí diran en esta guysa:

Que dio e pagó el dicho Gonçalo de Alua por my mandado al dicho Luys Garçía de Morales, my despensero, e por él a Áluaro de Mendoça e Juan de Monsalue, mys donseles, de sus raçiones que de my tienen este dicho año por quanto andan continuamente en my seruiçio siruiéndome de sus ofiçios, catorse mill e quatroçientos marauedís. xiiiiUcccc

Et que dio e pagó por my mandado al dicho Luys Garçía de Morales e por el a Juan de Preñán, my moço de alanos, del terçio primero de su raçión e tasa que de my tiene con el dicho ofiçio e ha de auer este dicho año, dos mill marauedís. iiU

Et que dio e pagó por my mandado al dicho Luys Garçía de Morales por el a Luys Gonçáles de Valladolid, my escudero de cauallo, del terçio primero de su raçión que de my tiene con el dicho ofiçio e ha de aver este dicho año, mill e quinientos marauedís. iUd

Et que dio e pagó por my mandado al dicho Luys Garçía de Morales por el a María Sánches, my panadera, del terçio primero de su raçión e tasa que de my tiene con el dicho ofiçio e ha de aver este dicho año, mill e nueueçientos e sesenta marauedís. iUdcccclx

Et que dio e pagó por my mandado al dicho Luys Garçía de Morales por él a Juan de Mendoça, my caçador, e a Juan Bernal, my cosinero, del terçio primero de sus raçiones que de my tienen con los dichos sus ofiçios e han de auer este dicho año, dos mill e seteçientos e treynta marauedís. iiUdccxxx

Et que dio e pagó por my mandado al dicho Luys Garçía de Morales por el a Rodrigo de Segovia, my repostero de capilla, e Juan Ferrándes de Carrión, my escudero de cauallo, del terçio primero de sus raçiones que de my tienen e han de aver con los dichos sus ofiçios este dicho año, dos mill e quatroçientos marauedís. iiUcccc

Et que dio e pagó por mi mandado al dicho Luys Garçía de Morales por él a Jayme de Yebra, mi capellan, e a Diego de Medina, mi moço de capilla, del terçio primero de sus raçiones que de mi tienen con los dichos ofiçios e han de aver este dicho año, dos mill e seysçientos e quarenta maravedís. iiUdcxl

Et que dio e pagó por mi mandado al dicho Luys Garçía de Morales por él a Alfonso de Cadahalso, my calçetero, del terçio primero de su raçión que de my tiene e ha de aver con el dicho su ofiçio este dicho año, mill marauedís. iU 
Et que dio e pagó por mi mandado al dicho Luys Garçía de Morales por él a Andrés de Toledo, my yluminador, del terçio primero de su raçión que de my tiene con el dicho su ofiçio e ha de auer este dicho año, mill e dosientos marauedís. iUcc

Et que dio e pagó por mi mandado al dicho Luys Garçía de Morales por él a Juan de Çibdad e a Alfonso Ferrándes de Santa María e a Ferrando de Llonbrales, mys monteros de cauallo, del terçio primero de sus raçiones que de my tienen con los dichos sus ofiçios e ouieron de aver este dicho años, quatro mill e seysçientos e ochenta marauedís. iiiiUdclxxx

Et que dio e pagó por mi mandado al dicho Luys Garçía de Morales por él a Martín de la Rua, my vallestero de maça, del terçio primero de su raçión que de my tiene con el dicho su ofiçio e ha de auer este dicho año, mill e tresientos marauedís. iUccc

Et que dio e pagó por mi mandado al dicho Luys Garçía de Morales e por él a Pricón, mi tronpeta, del terçio primero de su raçión que de mi tiene e ha de auer este dicho año con el dicho su ofiçio, dos mill e quatroçientos maravedís. iiUcccc

Et que dio e pagó por mi mandado al dicho Luys Garçía de Morales e por él a Aluar Ferrándes e Juan de Castro, mis organystas, del terçio primero de sus raçiones que de mi tienen e han de aver con el dicho su ofiçio este dicho año, seys mill e quatroçientos e sesenta e nueue marauedís. viUcccclxix

Et que dio e pagó por mi mandado al dicho Luys Garçía de Morales e por él a Gomes de Hoyos, my cauallerizo mayor, del terçio primero de su raçión que de my tiene e ha de auer con el dicho su ofiçio este dicho año, dos mill e quatroçientos marauedís. iiUcccc

Et que dio e pagó por mi mandado al dicho Luys Garçía de Morales e por él a Alfonso Sánches de Valladolid, my carniçero, del terçio primero de su raçión que de my tiene con el dicho su ofiçio e ha de auer este dicho año, mill e ochoçientos marauedís. iUdccc

Et que dio e pagó por mi mandado al dicho Luys Garçía de Morales e por él a Diego Guadalfajara, my mensajero de cauallo, del terçio primero de su raçión que de my tiene con el dicho su ofiçio e ha de auer este dicho año, mill e ochoçientos e seys marauedís e cuatro cornagos. iUdcccvi iiii cornados

(Al margen, a la derecha: lUdclxxxxv, iiii cornados)

Que montan todos los dichos marauedís en esta dicha my nómyna contenydos que así dio e pagó por my mandado en la manera que dicha es el dicho Gonçalo de Alua al dicho Luys Garçía de Morales, my despensero, e por el a las sobre dichas personas segund dicho es, çinquenta mill e seysçientos e ochenta e çinco marauedís e quatro cornados, los quales mando a vos los dichos mys contadores mayores de las mys cuentas que reçibades e pasedes en cuenta como dicho es al dicho Gonçalo de Alua de qualesquier marauedís e doblas e florines quel por my mandado ha reçebido e reçebiere en qualquier manera mostrando vos carta de pago del dicho Luys Garçía de Morales, my despendero, de los dichos çinquenta mill e seysçientos e ochenta e çinco marauedís e quatro cornados, et non fagades ende al.

Fecha diez días de agosto año del nasçimiento del nuestro señor Ihesuchristo de mill e quatroçientos e çinquenta e tres años.

Yo el rey.

Yo Bartolomé Sánches de Badajos lo fise escreuir por mandado de nuestro señor el rey. Registrada.

E en las espaldas de la dicha nomina fue sobrescripta esto que se sigue:

Contadores mayores del rey nuestro señor de las sus cuentas, los contadores mayores del dicho señor rey vos fasemos saber que se asentó esta nómyna en los sus libros. 
1453, agosto, 20.

Albalá de Juan II ordenando a Gonzalo de Alba, su repostero de camas, pagar al doctor Juan García de Narváez, chantre de Coria, fisico y capellán real, los 2.400 maravedies del tercio de su ración. AGS, CysR, leg. 42, f. $1 \mathrm{~m}$.

Yo el rey mando a vos Gonçalo de Alua, mi repostero de camas, que de más de las quatroçientas e çinquenta mill marauedís que vos por my mandado avedes dado e pagado para pagar las raçiones a algunos mys ofiçiales que continuamente me siruen sus terçios deste presente año de la fecha deste mi alualá o de más de otros qualesquier marauedís que para lo susodicho por my mandado avedes dado e pagado en qualquier manera, dedes e paguedes luego al doctor don Juan Garçía de Narbáes, chantre de Coria, my físico e capellán, dos mill e quatroçientos marauedís ques my merçed de le mandar dar del terçio de su raçión que de my tiene con el dicho ofiçio e ha de aver este dicho año e tomad su carta de pago con la qual e con esta mando que vos sean resçebidos en cuenta, e por este my alualá mando a los mys contadores mayores que descuente al dicho chantre los dichos dos mill e quatroçientos marauedís de la dicha su raçión al tienpo que ge la libraron e non fagades ende al.

Fecho veynte días de agosto año del nasçimiento del nuestro señor Ihesu Christo de mill e quatroçientos e çinquenta e tres años.

Yo el rey.

Yo Pero Ferrándes de Lorca los fis escreuir por mandado de nuestro señor el rey.

Registrada, Rodrigo.

Fue sobrescripto el dicho alualá para el dicho Gonçalo de Alua que lo vea e cunpla.

(Al margen, a la izquierda: Don Juan Garçía de Narbáes, chantre de Coria. Libraron este alualá los ofiçiales de las quitaçiones. Pasáronse al ofiçio de las quitaçiones que tiene Ruy Ferrándes de Jaén por fe por que alla tenía el dicho chantre la raçión e le deuen ser della descontados estos marauedís e por esto se testó de aquí este alualá)

(Al margen, a la derecha: iiUcccc)

\section{8}

1453, octubre, 15.

Albalá de Juan II ordenando a sus contadores mayores librar a Luis García de Morales, despensero mayor de las raciones de la Casa del rey, 3.000.000 de maravedies para el pago de las raciones y tasas de los oficiales de la Casa del rey.

AGS, CysR, leg. 42, f. $1 \mathrm{~m}$.

Luys Garçía de Morales, despensero mayor del rey nuestro señor, de las raçiones de su casa.

Mostró vn alualá del rey firmado de su nonbre que tenía Bartolomé Sánches de Basajos fecho en esta guisa:

Yo el rey mando a vos los mys contadores mayores que libredes luego a Luys Garçía de Morales, my despensero mayor de las raçiones de la my casa, tres cuentos de marauedís ques my merçed de le mandar librar pagar las dichas mys raçiones e tasas de la dicha my casa este año de la fecha deste my alualá, et librádgelos en qualesquier mys recabadadores e arrendadores mayores de los mys regnos señaladamente en los recadudadores e arrendadores quel dicho my despensero vos dixiere e señalare para que ge los ellos libren señaladamente en los lugares e rentas e personas quel dicho my despensero o los que lo ouieren de recabdar para él les señalaren e nonbraren para que ge los den e paguen por los terçios deste dicho año, e non fagades ende al.

Fecho quinse días de otubre año del nuestro señor Ihesu Christo de mill e quatroçientos e çinquenta e tres años.

Yo el rey.

Yo el doctor Fernando Días de Toledo, oydor e refrendario del rey e su secretario, lo fis escreuir por su mandado. 
Registrada, Garçía Gonçáles.

(Al margen, a la derecha: iii quentos marauedís)

9

1453, noviembre, 24.

Albalá de Juan II ordendo a Gonzalo de Alba, su repostero de camas, entregar a Luis García de Morales, despensero mayor de las raciones de la Casa del rey, 575.000 maravedies para el pago del segundo tercio de las raciones de algunos oficiales reales.

AGS, CysR, leg. 42, f. $1 \mathrm{~m}$.

Luys Garçía de Morales, despensero mayor del rey neustro señor de las raçiones e tasas de la su casa.

Mostró vn alualá del rey firmado de su nonbre fecho en esta guysa:

Yo el rey mando a vos Gonçalo de Alua, my repostero de camas que de qualesquier marauedís que vos por my mandado avedes reçebido e recabdado en qualquier manera dedes dellos a Luys Garçía de Morales, my despensero mayor de las raçiones de la my casa, quinientas e setenta e çinco mill marauedís que es my merçed de le mandar dar para pagar a çiertos mys criados e ofiçiales de la dicha my casa que continuamente me siruen el terçio segundo de sus raçiones e tasas que de my tienen e han de aver este año de la fecha deste my alualá, et dadgelos luego e tomad su carta de pago con la qual e con este my alualá mando que vos sean reçebidos en cuenta, et non fagades ende al.

Fecho veynte e quatro días de nouienbre año del nasçimiento de nuestro señor Ihesu Christo de mill e quatroçientos e çinquenta e tres años.

Yo el rey. Es la quantía quinientos e siete mill marauedís (sic).

Yo Diego Romero la fis escreuir por mandado de nuestro señor el rey.

Registrada, Garçía Gonçáles.

Fue sobrescripto en las espaldas de la dicha çédula para el dicho Gonçalo de Alua que la vea e cunpla.

(Al margen, a la izquierda: cámara. El dicho despensero)

(Al margen, a la derecha: dlxxU marauedís)

1453, diciembre, 3 .

Cédula de Juan II ordenando a Gonzalo de Alba, su repostero de camas, entregar 37.000 maravedies más de los 575.000 ya dados a Luys García de Morales, despensero mayor de las raciones de la Casa del rey, para pagar el tercio segundo de sus raciones correspondientes a 1453.

AGS, CySR, leg. 42, f. $1 \mathrm{~m}$.

Gonçalo de Alua, my repostero de camas, yo vos mando que de más de las quinientas e setenta e çinco mill marauedís que yo vos mande que diésedes a Luys Garçía de Morales, my despensero mayor de las raçiones de la my casa, dedes al dicho Luys Garçía treynta e siete mill marauedís para pagar a çiertos mys ofiçiales que es my merçed que asý mesmo se paguen de los marauedís de la my cámara el terçio segundo de sus raçiones que de my tienen e han de aver este presente año de la fecha desta my çédula, et dadgelos luego e tomad su carta de pago con la qual e con esta dicha çédula mando a los mys contadores mayores de las mys cuentas que vos reçiban en cuenta los dichos treynta e siete mill marauedís, et non fagades ende al.

Fecho tres días de disienbre año de mill e quatroçientos e çinquenta e tres años.

Yo el rey.

Por mandado del rey, Diego Romero.

Fue sobrescripto en las espaldas de la dicha çédula para el dicho Gonçalo de Alua que la vea e cunpla. (Al margen, a la derecha: xxxviiU) 
1453, diciembre, 3 .

Albalá de Juan II ordenando a Gonzalo de Alba, su repostero de camas, pagar al doctor Juan García de Narváez, chantre de Coria, físico y capellán real, los 2.400 maravedies del tercio segundo de su ración conrrespondiente a este año.

AGS, CysR, leg. 42, f. $1 \mathrm{~m}$.

Yo el rey mando a vos Gonçalo de Alua, mi repostero de camas, que de qualesquier marauedís que por my mandado avedes resçebido o resçibiéredes para los tener en la my cámara dedes e paguedes luego al doctor chantre de Coria, my físico e capellán, dos mill e quatroçientos marauedís del terçio segundo que ha de aver deste año de la fecha deste my alualá de su raçión que de my tiene con el dico ofiçio de capellán e dádgelos luego e tomad su carta de pago, con la qual e con este dicho my alualá mando que vos sean resçebidos en cuenta los dichos dos mill e quatroçientos marauedís, e por este dicho my alualá mando a los dichos mys contadores mayores que non libren al dicho doctor los dichos dos mill e quatroçientos marauedís del dicho terçio de la dicha su raçión deste dicho año en otra persona alguna, saluo que los resçiban en cuenta a vos el dicho Gonçalo de Alua como dicho es.

Fecho tres de disienbre año del nasçimiento del nuestro señor Ihesu Christo de mill e quatroçientos e çinquenta e tres años.

Yo el rey.

Yo Pero Ferrándes de Lorca lo fis escreuir por mandado de nuestro señor el rey.

Registrada.

Fue sobrescripto el dicho alualá en las espaldas para el dicho Gonçalo de Alua que lo vea e cunpla.

(Al margen, a la izquierda: el dicho chantre de Coria. Sobrescriuieron este alualá los ofiçiales de las quitaçiones. Pasose este alualá por real ofiçio de las rasyones que esta Ruy Ferrándes de Jaén por que all se deuia asentar porque alli tenia el dicho chantre la raçión e se den della descontados estos marauedís e por tanto se quita de aquí)

(Al margen, a la derecha: iiUcccc)

1453, diciembre, 4.

Cédula de Juan II de Castilla ordenando entregar a Luis García de Morales, despensero mayor de las raciones de la Casa del rey, para pagar a Juan Fernández de Valladolid los 1.080 maravedies del tercio segundo de su ración por el oficio de copero real.

AGS, CysR, leg. 42, f. $1 \mathrm{~m}$.

El rey.

Gonçalo de Alua, mi repostero de camas, yo vos mando que de más de las quinientas e setenta e çinco mill marauedís que vos por my mandado distes e pagastes a Luys Garçía de Morarles, my despensero mayor de las raçiones de la my casa, para pagar a çiertos mys criados e ofiçiales de la dicha my casa el terçio segundo de sus raçiones e tasas que de my tienen e ouieron de aver este presente año de la fecha desta my çédula, dedes e paguedes luego al dicho Luys Garçía, my despensero, mill e ochenta marauedís ques my merçed de le mandar dar para pagar el terçio segundo de la raçión de Juan Ferrándes de Valladolid, my copero, e tomad su carta de pago del dicho Luys Garçía con la qual e con esta my çédula mando que vos sean resçebidos en cuenta los dichos mill e ochenta marauedís, e non fagades ende al.

Fecho quatro días de disienbre año de (tachado: nasçimiento) liii.

$\mathrm{Al}$ qual mi despensero mando que vos lo de leuar do les vos libramiento de my mayordomo e contador de los dichos marauedís.

Yo el rey.

Por mandado del rey, Pero Ferrándes.

Fue sobrescripta en las espaldas de la dicha çédula para el dicho Gonçalo de Alua que la vea e cunpla. 
(Al margen, a la izquierda: Iohan Ferrándes de Valladolid, copero)

(Al margen, a la derecha: iUlxxx)

1453, diciembre, 11.

Cédula de Juan II ordenando a Gonzalo de Alba, su repostero de camas, dar a Luys García de Morales, despensero mayor de las raciones de la Casa del rey, los 1.580 maravedies que a Francisco de Alcalá le correspondian del tercio segundo de su ración correspondiente al año 1453 por el oficio de repostero de camas del monarca.

AGS, CysR, leg. 42, f. $1 \mathrm{~m}$.

\section{Cargo}

El rey.

Gonçalo de Alua, my repostero de camas, yo vos mando que de qualesquier marauedís que por my mandado tenedes en la my cámara para las cosas conplideras a mi seruiçio dedes a Luys Garçía de Morales, despensero mayor de las raçiones e tasas de my casa, mill e quinientos e ochenta marauedís de más de otros qualesquier marauedís que por my mandado le avedes dado este año de la fecha desta my çédula para pagar el terçio segundo de la raçión de Françisco de Alcalá, my repostero de camas, deste dicho año e dádgelos luegos e tomad su carta de pago e con ella e con esta my çédula mando que vos sean resçebidos en cuenta los dichos mill e quinientos e ochenta marauedís, e non fagades ende al.

Fecha honse de desienbre año de liii.

Yo el rey.

Por mandado del rey, relator.

Fue sobrescripto en las espaldas de la dicha çédula para el dicho Gonçalo de Alua que la vea e cunpla.

(Al margen, a la izquierda: el dicho Luys Garçía. Despensero)

\section{4}

1453, diciembre, 20. Valladolid.

Cédula de Juan II ordenado a Gonzalo de Alba, repostero de camas del rey, librar 7.200 maravedies a Luys García de Morales, despensero mayor de las raciones de la Casa del rey, para el pago en cuenta de la ración que Juan de Monsalve tenía por el oficio de maestresala del rey.

AGS, CysR, leg. 42, f. $1 \mathrm{~m}$.

El rey.

Gonçalo de Alua, mi repostero de camas, yo vos mando que de qualesquier marauedís que vos por my mandado avedes resçebido e resybieredes en qualquier manera este año de la fecha desta my çédula que dedes luego a Luys Garçía de Morales, my despensero mayor de las raçiones e tasas de la my casa, siete mill e dosientos marauedís ques my merçed de le mandar dar para que los el de e pague a Juan de Monsalve, mi maestresala, en cuenta de la raçión quel de my tiene del dicho ofiçio por quanto el dicho Juan de Monsalue me sirue aquí conmigo en la my corte residentemente en el dicho su ofiçio de my maestresala, e tomad su carta de pago del dicho Luys Garçía con la qual e con esta çédula mando a los mys contadores mayores de las mys cuentas que vos resçiban e pasen en cuenta, e non fagades ende al.

De la villa de Valladolid a veynte días de desienbre año de çinquenta e tres años. Va emendado o dis Valladolid e disienbre.

Yo el rey.

Por mandado del rey, Pero Ferrándes.

E en las espaldas de la dicha çédula fue escripto para el dicho Gonçalo de Alua que la vea e cunpla.

(Al margen, a la derecha: viiUcc) 
1453, diciembre, 24

Cédula de Juan II de Castilla ordenando a Gonzalo de Alba, su repostero de camas, entregar a Luis Garcia de Morales, despensero mayor de las raciones de la Casa del rey, 1.443 maravedies para el pago del tercio segundo de 1453 que Luis González de Valladolid tenía por escudero de a caballo del rey.

AGS, CysR, leg. 42, f. $1 \mathrm{~m}$.

El rey.

Gonçalo de Alua, mi repostero de camas, yo vos mando que de mas de las quinientas e setenta e çinco mill marauedís que vos por my mandado distes e pagastes a Luys Garçía de Morales, my despensero mayor de las raçiones de la my casa, para pagar el terçio segundo de sus raçiones a çiertos mys ofiçiales de la my casa este año de la fecha desta my çédula dedes e paguedes luego al dicho Luys Garçía mill e quatroçientos e quarenta e tres marauedís de qualesquier marauedís que vos por my mandado avedes resçebido e recabdado o reçebiéredes o recabdáredes para que los él de e pague al Luy Gonçáles de Valladolid, my escudero de a cauallo, del terçio segundo de su raçión que de my tiene e ha de aver este dicho año por quanto el ha andado e anda aquí en la my corte continuamente e en my seruiçio, e non fagades ende al.

Fecho (tachado: catorse) veynte e quatro días de disienbre año de iUcccc e çinquenta e tres años.

Yo el rey.

Por mandado del rey, relator.

Fue sobrescripta en las espaldas del dicho alualá para el dicho Gonçalo de Alua que lo vea e cunpla. (Al margen, a la derecha: iUccccxliii marauedís)

Fragmento de una cédula de Juan II ordenado a Gonzalo de Alba, repostero de camas del rey, librar a Luys García de Morales, despensero mayor de las raciones de la Casa del rey, para el pago del tercio segundo de la ración de 3.400 maravedies que por tenor de la capilla tenía Guillemín Francés.

AGS, CysR, leg. 42, f. $1 \mathrm{~m}$.

El rey.

(Tachado: Gonçalo de Alua, mi repostero de camas, yo vos mando que de qualesquier marauedís que por my mandado avedes reçebido o reçibiéredes en qualquier manera para los tener en la my cámara dedes e paguedes luego a Luys Garçía de Morales, my despensero mayor de las raçiones de la my casa, tres mill e quatroçientos marauedís ques my merçed que los él resçiba de vos para los dar e pagar a Guillemín Françés, thenor de la my capilla, para en cuenta de su raçión que de my tiene e ha de aver del terçio segundo...)

(Al margen, a la izquierda: yerro)

1454, enero, 22.

Albalá de Juan II de Castilla ordenando a García Sánchez de Valladolid, su contador mayor y contador de la reina Isabel, 80.000 maravedies, de los 3.000.000 millones de maravedis destinados en 1453 para el pago de raciones y tasas de los oficiales de la Casa Real, para satisfacer las raciones de algunos cazadores del rey. Esta última cantidad procedería del pan, maravedies, rentas y pechos de Villafrechós durante el tiempo que estuvo en secuestración por orden real.

AGS, CysR, leg. 42, f. $1 \mathrm{~m}$.

El dicho Luys Garçía de Morales, despensero mayor de las raçiones de la casa del rey. 
Mostró vn alualá del rey nuestro señor firmado de su nonbre fecho en esta guisa:

Yo el rey fago saber a vos Garçía Sánches de Valladolid, my contador e contador mayor de la reyna, my muy cara e muy amada muger, que my merçed fue de mandar librar el año que pasó de mill e quatroçientos e çinquenta e tres años a Luys Garçía de Morales, my despensero mayor para las raçiones e tasas de la my casa del dicho año, tres cuentos de marauedís en cuenta de los quales es my merçed de le mandar librar en vos ochenta mill marauedís para que ge los dedes e paguedes del pan e marauedís e rentas e pechos e derechos de la villa de Villafrechós del dicho año que por my mandado resçebistes e recabdastes en secuestraçión por el poder que vos dí al tienpo que mande que toviésedes en secrestaçion la dicha villa o en otra qualquier manera por quel prestamente pueda pagar dellos algunos my caçadores sus raçiones que asý en el mande librar el dicho año.

Por que vos mando que del dicho pan e marauedís e rentas e cosas que asý reçebistes en la dicha Villafrechós e su tierra dedes e paguedes luego al dicho Luys Garçía o a quien su poder ouiere los dichos ochenta mill marauedís e tomad su carta de pago o del que su poder ouiere con la qual e con esta my carta mando a los mys contadores mayores de las mys cuentas e a qualquier otro ofiçial e persona que en ello aya de ver e a quien pertenesçe que vos lo resçiban en cuenta, et non fagades ende al.

Fecho veynte e dos días de enero año del nasçimiento del nuestro señor Ihesu Christo de mill e quatroçientos e çinquenta e quatro años.

Yo el rey.

Yo Pero Ferrándes de Lorca lo fise escreuir por mandado de nuestro señor el rey.

Registrada, Garçía Gonçáles.

Fue sobrescripto en las espaldas del dicho alualá para el dicho Garçía Sánches qu elo vea e cunpla.

(Al margen, a la izquierda: el dicho despensero. En cuenta de los dichos iii quentos de marauedís. Ordinario)

(Al margen, a la derecha: lxxxU marauedís)

1454, enero, 25.

Informe del mayordomo y contador de la despensa de la mesa del rey sobre el número de bestias por mes que estuvieron en la caballeriza real entre enero y agosto de 1453.

AGS, CysR, leg. 42, f. $1 \mathrm{~m}$.

Señores mayordomo e contador de la despensa e raçiones de la cada del rey nuestro señor.

El mayordomo e contador de la despensa de la mesa del dicho señor rey vos fasemos saber que estouieron en la caualleriza del dicho señor rey el año que pasó de mill e quatroçientos e çinquenta e tres años las bestias que aquí dyran en esta guysa, del qual diho cauallerizo tyene de tasa para cada vna en cada mes ochenta marauedís:

Enero

Que estouieron en la dicha cauallerysa el dicho año de çinquenta e tres años dies e seys bestias a rasón de los dichos ochenta marauedís cada vna que son mill e dosyentos e ochenta marauedís.

iUcclxxx marauedís

Febrero

Que estouieron en la dicha cauallerysa todo el mes de febrero las dichas dies e seys bestias a rasón de los dichos ochenta marauedís cada vna que son mill e dosyentos e ochenta marauedís.

iUcclxxx marauedís

Março

Que estouieron en la dicha cauallerysa del dicho señor rey en todo el dicho mes de março las dichas dies e seys bestias a rasón de los dichos ochenta marauedís cada vna que son mill e dosyentos e ochenta marauedís.

iUcclxxx marauedís 
Abril

Que estouieron en la dicha cauallerysa en todo el dicho mes de abril dies e syete bestias a rasón de los dichos ochenta marauedís cada vna que son mill e tresyentos e sesenta marauedís.

iUccclx marauedís

Mayo

Que estouieron en la dicha cauallerysa en todo el dicho mes de mayo dies e ocho bestias a rasón de los dichos ochenta marauedís cada vna que son mill e quatroçientos e quarenta marauedís.

iUccccxl marauedís

Junio

Que estouieron en la dicha cauallerysa en todo el mes de junio dies e ocho bestias a rasón de los dichos ochenta marauedís cada vna que son mill e quatroçientos e quarneta marauedís.

iUccccxl marauedís

Julio

Que estouieron en la dicha cauallerysa en todo el dicho mes de jullyo dies e syete bestias a rasón de los dichos ochenta marauedís cada vna que son mill e tresyentos e sesenta marauedís.

iUccclx marauedís

Agosto

Que estouieron en la dicha cauallerysa en todo el dicho mes de agosto del dicho año dies e ocho bestias a rasón de los dichos ochenta marauedís que son mill e quatroçientos e quarenta marauedís.

iUccccxl marauedís

Que montan todos los dichos marauedís quel dicho caualleryso ha de aver el dicho año pasado de mill e quatroçientos e çinquenta e tres años en la manera que dicha es dies mill e ochoçientos e nouenta e marauedís de los quales nos los dichos mayordomo e contador de la dicha despensa de la mesa del dicho señor rey que aquí firmamos nuestros nonbres fasemos fe.

Fecho veynte e çinco dyas del mes de enero año del nasçimyento del nuestro señor Ihesu Christo de mill e quatroçientos e çinquenta e quatro años.

Rodrigo de Castañeda. Martýn Ruis.

1454, febrero, 6.

Cédula de Juan II ordenando a Gonzalo de Alba, su repostero de camas, entregar 3.420 maravedies a Luis García de Morales, despensero mayor de las raciones de la Casa del rey, para pagar a Guillemýn Menasir, tenor, el tercio primero de su ración anual.

AGS, CysR, leg. 42, f. $1 \mathrm{~m}$.

El rey.

Gonçalo de Alua, mi repostero de camas, yo vos mando que de más e allende de qualesquier maravedís que vos por mi mandado auedes dado a Luys Garçía de Morales, despensero mayor de las raçiones de la mi casa, dedes luego al dicho Luis Garçía de Morales tres mill e quatroçientos e veynte maravedís que los ha de aver para pagar el terçio primero de la raçión que de mi tyene Guillemýn Menasir, mi thenor, este año de la fecha de este mi alualá, e tomad su carta de pago con la qual e con esta mi çédola mando que vos sean rresçibidos en cuenta los dichos tres mill e quatroçientos e veynte maravedís.

Fecha seys días de febrero año de mill e quatroçientos e çinquenta e quatro años.

Yo el rey. 
Por mandado del rey, relator.

Fue sobrecripto en las espaldas de la dicha çédola para el dicho Gonçalo de Alua que la vea e cunpla. (Al margen, a la derecha: iiiUccccxx)

1454 , febrero, 6 .

Cédula de Juan II ordenado a Gonzalo de Alba, su repostero de camas, entregar 798 maravedies a Luis García de Morales, despensero mayor de las raciones de la Casa del Rey, para pagar a Guillemýn Menasir, tenor del rey, lo que se le debian en concepto de ración del año 1453.

AGS, CysR, leg. 42, f. $1 \mathrm{~m}$.

El rey.

Gonçalo de Alua, mi repostero de camas, yo vos mando que de mas e allende de qualesquier maravedís que vos por mi mandado distes a Luys Garçía de Morales, mi despensero mayor de las raçiones de mi casa, dedes luego al dicho Luys Garçía de Morales seteçientos e nouenta e ocho maravedís que los ha de aver para pagar a Guillemýn Menasir, mi thenor, los maravedís que le son deuidos de su raçión que de mi tyene e ouo de aver el año que pasó de mill e quatroçientos e çinquenta e tres años, e tomad su carta de pago con la qual e con esta mi çédola mando que vos sean resçibidos en cuenta los dichos seteçientos e nouenta e ocho maravedís, e non fagades ende al.

Fecha a seys días de febrero año de mill e quatroçientos e çinquenta e quatro años.

Yo el rey.

Por mandado del rey, relator.

Fue sobrescripto en las espaldas de la dicha çédola para el dicho Gonçalo de Alua que la vea e cunpla. (Al margen, a la derecha: dccxcviii marauedís)

1454, febrero, 12.

Cédula de Juan II de Castilla ordenando a Gonzalo de Alba, su repostero de camas, entregar a Luis Garcia de Morales, despensero mayor de las raciones de la Casa del rey, 3.000 maravedies para el pago del último tercio de 1453 que Fernando de Sevilla tenía por el oficio de cantor del rey.

AGS, CysR, leg. 42 , f. $1 \mathrm{~m}$.

El rey.

Gonçalo de Alua, mi repostero de camas, yo vos mando que de qualesquier marauedís o doblas o florines que por my mandado avedes reçebido fasta aquí e resçibiéredes de aquí adelante en qualquier manera dedes luego a Luys Garçía de Morales, my despensero mayor de las raçiones de la my casa, tres mill maraudis que los ha de aver para pagar a Ferrando de Seuilla my cantor, del terçio postrimero de su raçión que de my tiene con el dicho ofiçio e ouo de aver el año que pasó de iUccccliii años a rasón de xxv marauedís cada dia e tomad su carta de pago del dicho Luys Garçía, con la qual e con este my alualá mando que vos sean resçebidos en cuenta, e non fagades ende al.

Fecho a xii días de febrero de liiii.

Yo el rey.

Por mandado del rey, relator.

Fue sobrescripto en las espaldas de la dicha çédula para el dicho Gonçalo de Alula que lo vea e cunpla

(Al margen, a la derecha: iiiU)

1454, febrero, 12.

Cédula de Juan II ordenando a Gonzalo de Alba, su repostero de camas, entregar a Luis García 
de Morales, despensero mayor de las raciones de la Casa del rey, 3.260 maravedies para pagar al organista real Álvaro Fernández el último tercio de su ración correspondiente al año 1453.

AGS, CysR, leg. 42 , f. $1 \mathrm{~m}$.

Mostró vna çédula del rey nuestro señor fecha en esta guisa:

El rey.

Gonçalo de Alua, mi repostero de camas, yo vos mando que de mas e allende de otros qualesquier maravedís que en vos aya librado a Luys Garçía de Morales, mi despensero mayor de las raçiones de la mi casa, para pagar el terçio segundo de la dicha mi casa a çiertos mis ofiçiales del año que pasó de mill e quatroçientos e çinquenta e tres años, dedes luego al dicho Luys Garçía de Morales tres mill e dosientos e sesenta maravedís que los ha de aver para pagar el terçio postrimero del dicho año año pasado a Áluaro Ferrándes, mi organista, e tomad su carta de pago con la qual e con esta mi çédula mando que vos sean rresçebidos en cuenta los dichos tres mill e dosientos e sesenta maravedís e no fagades en de al.

Fecho a dose días de febrero año de mill e quatroçientos e çinquenta e quatro años.

Yo el rey.

Por mandado del rey, Pero Ferrándes.

Fue sobrescripto en las espaldas de la dicha çédula para el dicho Gonçalo de Alua que lo vea e cunpla. (Al margen, a la izquierda: Aluar Ferrándes, organista)

(Al margen, a la derecha: iiiUcclx marauedís)

1454, febrero, 13 .

Cédula de Juan II ordenado a Gonzalo de Alba, repostero de camas del rey, librar 2.400 maravedies a Luys García de Morales, despensero mayor de las raciones de la Casa del rey, para el pago del tercio segundo de la ración que le correspondía a Toledo, rey de armas, por dicho oficio.

AGS, CySR, leg. 42, f. $1 \mathrm{~m}$.

El rey.

Gonçalo de Alua, mi repostero de camas, o vos mando que de más e allende de otros qualesquier marauedís que yo aya librado a Luys Garçía de Morales, mi despensero mayor de las raçiones de la my casa, para pagar el terçio segundo de las raçiones de la dicha my casa a çiertos my ofiçiales del año que pasó de iUccccliii años, desde luego al dicho Luys Garçía de Morales iiiiUcc marauedís que los ha de aver para pagar el terçio segundo de la raçión del dicho año pasado a Toledo, my rey de armas, e tomad su carta de pago con la qual e con esta my çédula mando que vos sean reçebidos en cuenta los dichos iiiiUcc marauedís, e non fagades ende al.

Fecho xiii días de febrero año de liiii.

Yo el rey.

Por mandado del rey, relator.

Fue sobrescripto en las espaldas de la dicha çédula para el dicho Gonçalo de Alua que la vea e cunpla. (Al margen, a la derecha: iiiiUcc)

1454, febrero, 15.

Albalá de Juan II ordenando a sus contadores mayores librar a Gómez de Hoyos, su caballerizo mayor, 19.896 maravedies para el pago de las tasas de los caballos, mulas y jacas de la caballeriza real correspondiente al año 1453.

AGS, CysR, leg. 42, f. $1 \mathrm{~m}$.

Gomes de Hoyos, cauallerizo mayor del rey nuestro señor.

Mostró vn alualá del rey nuestro señor firmado de su nonbre e çiertas fees que tiene Bartolomé de Badajos fechos en esta guisa: 
Yo el rey mando a vos los mys contadores mayores que libredes a Gómes de Hoyos, my cauallerizo mayor, dies e nueue mill e ochoçientos e nouenta marauedís que ha de aver de las tasas que de my tyene para los cauallos e mulas e trotones e hacas de la my caualleriza, et otrosy para dos aseylas con que syrva a la dicha my cauallerisa, los quales vno a de aver del año pasado de mill e quatroçientos e çinquenta e tres años a rasón de ochenta marauedís cada mes cada bestia et para las dichas dos asémylas tres mill marauedís por todo el año en que montaron los dichos dies e nueue mill e ochoçientos e ochenta marauedís segund lo mostró todo ante my por fe del my mayordomo e contador de la despensa e raçiones de la my casa, et libradgelos señaladamente en el my reçebtor de la villa de Ledesma e su tierra del dicho año pasado para que ge los den e paguen luego en dineros contados, e non fagades ende al.

Fecho quinse días de febrero año del nasçimyento del nuestro señor Ihesu Christo de mill e quatroçientos e çinquenta e quatro años.

Yo el rey.

Yo Pero Ferrándes de Lorca lo fis escreuir por manado de nuestro señor el rey.

Registrada.

Alualá, Bartolomé de Badajos.

(Al margen, a la izquierda: el dicho despensero. En cuenta de los marauedís de la cámara. Tasas cauallerisa. Resgose este alualá e libraáronse por otro alualá en el reçebtor de la dicha villa de Ledesma en el año de liiii segund adelante se contiene).

1454, febrero, 18.

Cédula de Juan II ordenando a sus contadores mayores librar a Luis García de Morales, despensero mayor de las raciones de la Casa del rey, 6.000 maravedies para el pago de los tercios primero y último de la ración (25 maravedies diarios) correspondeinte a 1453 a Juan Martínez de Villarreal por capellán y cantor de la capilla del rey.

AGS, CysR, leg. 42, f. $1 \mathrm{~m}$.

El rey.

Gonçalo de Alua, my repostero de camas, yo vos mando que de qualesquier marauedís e doblas e florines que (por) my mandado avedes reçebido o resçebiéredes de aquí adelante en qualquier manera dedes luego a Luys Garçía de Morales, my despensero mayor de las raçiones de la my casa, seys mill marauedís que los ha de aver para pagar a Juan Martínes de Villarreal, my capellan e cantor de la my capilla, de los dos terçios primero e postrimero de su raçión que de my tiene con el dicho ofiçio e ovo de aver el año que pasó de mill e quatroçientos e çinquenta e tress años a rasón de veynte e çinco marauedís cada dia, et tomad su carta de pago del dicho Luys Garçía de Morales con la qual e con este my alualá mando que vos sean resçebidos en cuenta, e non fagades ende al.

Fecho dies e ocho días de febrero año de iUccccliiii años.

Yo el rey.

Por mandado del rey, relator.

\section{6}

1454, febrero, 28.

Informe del mayordomo y contador de la despensa de la mesa del rey sobre el número de bestias por mes que estuvieron en la caballeriza real entre septiembre y diciembre de 1453. Se añade fé de estos mismos oficiales señalando que los 3.000 maravedies que le caballerizo mayor del rey, Gómez de Hoyos, tenía de tasa para dos acémilas ese año no se le habían librado todavía.

AGS, CysR, leg. 42, f. $1 \mathrm{~m}$.

Señores mayordomo e contador de la despensa e raçiones de la casa del rey nuestro señor, el mayordomo e contador de la despensa de la mesa del dicho señor rey vos fasemos saber que estavieron en 
la caualleriza del dicho señor rey el año que pasó de mill e quatroçientos e çinquenta e tres años las bestias que aquí dyran de quel dicho caualleryso tiene tasa para cada van cada mes ochenta marauedís en esta guisa:

Setyenbre

Estouieron en la dicha cauallerisa en todo el mes de setyenbre del dicho año de çinquenta e tres, dies e ocho bestias a rasón de los dichos ochenta marauedís a cada vna cada mes que son mill e quatroçientos e quarenta marauedís.

iUccccxl marauedís

Otubre

Estouieron en al dicha cauallerisa en todo el mes de otubre del dicho año de çinquenta e tres, dies e nueue bestias a rasón de los dichos ochenta marauedís a cada vna cada mes que son mill e quinientos e veynte marauedís.

iUdxx marauedís

Nouienbre

Estouieron en la dicha cauallerysa en todo el mes de nouienbre dies e nueue bestyas a rasón de los dichos ochenta marauedís a cada vna cada mes que son mill e quinientos e veynte marauedís.

iUdxx marauedís

Disyenbre

Estouieron en la dicha cauallerisa en todo el mes de sesyenbre el dicho año dies e nueve bestyas a rasón de ochenta marauedís cada vna cada mes mill e quinientos e veynte marauedís.

iUdxx marauedís

Que montan todos los dichos marauedís quel dicho caualleriso ovo de aver en los dichos meses del dicho año pasado en la manera que dicha es, seys mill marauedís de los quales, nos, el dicho mayordomo e contador de la dicha despensa de la mesa del dicho señor rey que aquí firmamos nuestros nonbres e fasemos fe.

Fecho postrimero dya de febrero año del nasçimyento del nuestro señor Ihesu Christo de mill e quatroçientos e çinquenta e tres años.

Juan de Valladolid. Martýn Ruys.

Fallase por los libros de la casa del rey nuestro señor que tyene el su mayordomo e contador de la despensa e raçiones de la cada del rey nuestro señor que tyene el su mayordomo e contador de la despensa e raçiones de la dicha su cama en como Gomes de Hoyos, caualleryso del dicho señor rey, tyene de tasa cada año para dos aseymilas tres mill marauedís, los quales pareçen por los dichos libros como le non fueron librados el año que pasó de mill e quatroçientos e çinquenta e tres años, en fe de lo qual el dicho mayordomo e contador aquí fyrmamos nuestros nonbres.

Fecha a wuinse dyas de febrero año del nasçimiento del nuestro señor Ihesu Christo de mill e quatroçientos e çinquenta e quatro años.

Pero Rodrigues. Garçía Gonçáles.

Fe es de Bartolomé de Badajos.

1454, marzo, 6.

Albalá de Juan II ordenando a sus contadores mayores librar a Gómez de Hoyos, caballerizo mayor del rey, 19.890 maravedies de las tasas que le correspondian de la caballeriza del rey y las dos acémilas con las que sirve en dicha caballeriza del año 1453.

AGS, CysR, leg. 42, f. $1 \mathrm{~m}$. 
El dicho Gomes de Hoyos, cauallerizo.

Mostró vn alualá del rey nuestro señor firmado de su nonbre e otrosy vna fe del su mayordomo e contador firmadas de sus nonbres fechos en esta guisa:

Yo el rey mando a vos los mys contadores mayores que libredes a Gómes de Hoyos, my cauallerizo mayor, dies e nueue mill e ochoçientos e nouenta marauedís que ha de aver de las tasas que de my tiene para los cauallos e mulas e trotones e hacas de la my caualleria (sic), et otrosy para dos azemylas con que sirue la dicha my cauallerisa, los quales ouo de aver el año pasado de mil e quatroçientos e çinquenta e tres años a rasónde ochenta marauedís cada mes a cada bestia e para las dichas dos asemilas tres mill marauedís por todo el año en que montaron los dichos dies e mueue mill e ochoçientos e nouenta marauedís segund lo Mostró ante my por fe del my mayordomo e contador de la despensa e raçiones de la my cada, et libradgelos señaladamente en el my reçebtor de la villa de Ledesma e de su tierra en los marauedís de las mys rentas de la dicha villa e su tierra deste presente año de la fecha desta my alauala apra que ge los den e paguen luego en dinero contados, et non fagades ende al.

Fecho seys días de março año del nasçimyento del nuestro señor Ihesu Christo de mill e quatroçientos e çinquenta e quatro años.

Yo el rey.

Yo Pero Ferrándes de Lorca lo fis escreuir por mandado de nuestro señor el rey.

Registrada, Garçía Gonçáles.

1454, marzo, 13.

Cédula de Juan II ordendo a Gonzalo de Alba, su repostero de camas, entregar a Luis García de Morales, despensero mayor de las raciones de la Casa del rey, 3.000 maravedies para el pago del primer tercio de 1453 que se le debía a Hans de Ulm ${ }^{298}$ por el oficio del platero del rey.

AGS, CysR, leg. 42, f. $1 \mathrm{~m}$.

El rey.

Gonçalo de Alua, mi repostero de camas, yo vos mando que de qualesquier doblas e florines e marauedís que por my mandado auedes resçebido o resçibiéredes de aquí adelante en qualquier manera dedes luego a Luys Garçía de Morales, mi despensero mayor de las raçiones de la my casa, tres mill marauedís para pagar a Ançe Dolmo, my platero, del terçio primero de su raçión que con el dicho ofiçio de mi tiene et le fincó por pagar el año que pasó de mill e quatroçientos e çinquenta e tres años segund paresçe por vn libramiento que de los dichos marauedís fue fecho para el my mayordomo e contador al dicho Ançe Dolmo en el dicho my despensero por virtud del qual ge los han de resçibir en cuenta al dicho mi despensero el dicho my mayordomo e contador, e tomad su carta de pago del dicho Luys Garçía, con la qual e con este my alualá mando que vos sean resçebidos en cuenta, e non fagades ende al.

Fecho a trese días del mes de março año del nasçimiento del nuestro señor Ihesu Christo de mill e quatroçientos e çinquenta e quatro años.

Yo el rey.

Por mandado del rey, relator.

Fue sobrescripta en las espaldas de la dicha çédula para el dicho Gonçalo de Alua que lo vea e cunpla. (Al margen, a la derecha: iiiU)

1454, abril, 5.

Albalá de Juan II ordenando a Gonzalo de Alba, su repostero de camas, entregar 650.000 maravedies a Luis García de Morales, despensero mayor de las raciones de la Casa del rey, para el pago a

${ }^{298}$ Platero alemán al servicio de Juan II de Castilla. 
los oficiales de la Casa Real correspondiente al último tercio de 1453.

AGs, CysR, leg. 42, f. $1 \mathrm{~m}$.

Yo el rey mando a vos Gonçalo de Alua, mi repostero de camas, que de qualesquier marauedís que vos por my auedes reçebido e recabdado en qualquier manera dedes dellos a Luys Garçía de Morales, my despensero mayor de las raçiones de la my casa, seysçientos e çinquenta mill marauedís ques my merçed de le mandar dar para pagar a çiertos mys ofiçiales de la dicha my casa que contynuamente me syrven el terçio postrimero de sus raçiones e tasas que de my tyenen e han de aver el año pasado de mill e quatroçientos e çinquenta e tres años, et dádgelos luego e tomad su carta de pago con la qual e con esta my çédula mando a los mys contadores mayores de las mys cuentas que vos los resçiban e pasen en cuenta, e non fagades ende al.

Fecho çinco días de abril año del nasçimiento del nuestro señor de mill e quatroçientos e çinquenta e quatro años. Es la quantía seysçientos e çinquenta mill marauedís.

Yo el rey.

Yo Diego Romero lo fis escreuir por mandado de nuestro señor el rey.

Registrada.

Fue sobrescripto en las espaldas de la dicha çédula para el dicho Gonçalo de Alua que la vea e cunpla. (Al margen, a la derecha: dclU marauedís)

1454, abril, 25.

Cédula de Juan II ordenado a Gonzalo de Alba, su repostero de camas, entregar 8.000 maravedies a Luis García de Morales, despensero mayor de las raciones de la Casa del rey, para pagar el tercio primero de las raciones de Pedro de Fox, Cornalis de Alemania, Martín Muñoz del Cardoso y Sancho Barquero, ministriles de chirimía del monarca.

AGS, CysR, leg. 42, f. $1 \mathrm{~m}$.

Luys Garçía de Morales, despensero mayor de nuestro señor el rey de las raçiones del dicho señor rey de la su casa.

Mostró vna çédula del rey nuestro señor firmada de su nonbre fecha en esta guisa:

El rey.

Gonçalo de Alua, mi repostero de camas, yo vos mando que de qualesquier maravedís que por mi mandado auedes resçebido o rrescebiéredes en qualquier manera para los tener en la mi cámara dedes e paguedes luego a Luis Garçía de Morales, mi despensero mayor de las raçiones de la mi casa, ocho mill maravedís que es mi merçed que los resçiba de vos para los dar e pagar a Pedro de Fox e Cornalis de Alemaña e a Martýn Muñoz del Cardoso e a Sancho Barquero, mis ministriles de cheremías, a cada vno de ellos dos mill maravedís para en cuenta de sus raçiones que de mi tyenen e han de aver del terçio primero de este año de la fecha de esta mi çédula e dadgelos e pagadgelos luego e tomad su carta de pago con la qual e con con esta mi çédula mando a los mis contadores mayores de las mis cuentas que vos resçiban en cuenta los dichos ocho mill maravedís e non fagades ende al.

Fecho veynte e çinco días de abril año del nasçimiento del nuestro señor Ihesu Christo de mill e quatroçientos e çinquenta e quatro años.

Yo el rey.

Por mandado del rey, Pero Ferrándes.

E en las espaldas de la dicha çédula estaua escripto esto que se sygue: Gonçalo de Alua, repostero de camas del rey nuestro señor, de esta otra parte contenydo ved esta çédula del dicho señor rrey e conplidla en todo e por todo segund se en ella contyene e su altesa por ella vos enbia mandar.

(Al margen, a la izquierda: año de iUccccliiii años. Cámara. El despensero Luys Garçía)

(Al margen, a la derecha: viiiU marauedís) 
1454, abril, 30.

Cédula de Juan II ordenado a Gonzalo de Alba, repostero de camas del rey, librar 2.760 maravedies a Luys García de Morales, despensero mayor de las raciones de la Casa del rey, para el pago del último tercio de las raciones que le correspondian a Pedro de Cuéllar y Sancho Martínez de Segovia por sus oficios de ballestero de caballo y escudero de caballo respectivamente.

AGS, CysR, leg. 42, f. $1 \mathrm{~m}$.

El rey.

Gonçalo de Alua, mi repostero de camas, yo vos mando que de más e allende de las seysçientas e çinquenta mill marauedís que vos por my mandado distes a Luys Garçía de Morales, mi despensero mayor de las raçiones et tasas de la my casa, para pagar a çiertos mys ofiçiales el terçio postrimero de las dichas raçiones del año que pasó de mill e quatroçientos e çinquenta e tres años dedes luego al dicho Luys Garçía de Morales dos mill e seteçientos et sesenta marauedís que los ha de aver para pagar los terçios postrimeros de sus raçiones del dicho año pasado a Pedro de Cuéllar, my vallestero de cauallo, e a Sancho Martínes de Segouia, my escudero de cauallo, et tomad sus cartas de pago con las quales e con este my alualá mando que vos sean resçebidos en cuenta los dichos dos mill et seteçientos e sesenta marauedís.

Fecha a treynta días de abril año de çinquenta e quatro.

Yo el rey.

Por mandado del rey, relator.

Et en las espaldas de la dicha çédula fue escripto para quel dicho Gonçalo de Alua que la vea e cnpla en todo e por todo segund que en ella se contiene.

(Al margen, a la derecha: iiUdcclx marauedís)

1454, mayo, 3. Tordesillas

Cédula de Juan II de Castilla ordenando a Gonzalo de Alba, su repostero de camas, entregar a Luys García de Morales, pagar los 2.400 maravedies correspondientes al último tercio de 1453 y primer tercio de 1454 que en concepto de ración por escribano de cámara del rey tenía Lope González de Alcalá.

AGS, CysR, leg. 42 , f. $1 \mathrm{~m}$.

El rey.

Gonçalo de Alua, mi repostero de camas, yo vos mando que de qualesquier marauedís que por mi mandado avedes resçebido o resçibiéredes para los tener en la my corte en la my cámara para las cosas conplideras a mi seruiçio, dedes luego a Luys Garçía de Morales, my despensero mayor de las raçiones (tachado: de la my casa) e tasas de la my casa iiUcccc marauedís para que pague a Lope Gonçáles de Alcalá, my escriuano de cámara, del terçio postrimero de su raçión que de my tyene del año que pasó de iUccccliii años e del terçio ¿primero? de la dicha su raçión deste año de la fecha desta çédula segund paresçe por vn libramiento que de los dichos marauedís fue fecho por el my mayordomo e contador al dicho Lope Gonçáles de Acalá en el dicho my despensero por virtud del qual ge los ha de resçebir en cuenta, e tomad su carta de pago con la qual e con este my alualá mando que vos sean resçebidos en cuenta, e non fagades ende al.

Dada en la villa de Oterdesillas a iii días de mayo año del nasçimiento del nuestro señor Ihesu Christo de iUccccliiii años.

Yo el rey.

Por mandado del rey, relator.

Fue sobrescripta en las espaldas de la dicha çédula para el dicho Gonçalo de Alua que lo vea e cunpla.

(Al margen, a la izquierda: asentose por relaçion en la cuenta del dicho despensero de la cámara del año de liiii los iiU marauedís de los que son del terçio primero del dicho año de liiii)

(Al margen, a la derecha: [tachado: iiUcccc marauedís] iUcc marauedís) 
1454, mayo, 3 .

Cédula de Juan II ordenado a Gonzalo de Alba, repostero de camas del rey, librar 1.440 maravedies a Luys García de Morales, despensero mayor de las raciones de la Casa del rey, para el pago del tercer y último tercio de la ración correspondiente a 1453 que por repostero de camas tenía Francisco de Alcala. AGS, CysR, leg. 42, f. $1 \mathrm{~m}$.

El rey.

Gonçalo de Alua, mi repostero de camas, yo vos mando que de más de qualesquier marauedís que vos por my mandado avedes dado a Luys Garçía de Morales, my despensero mayor de las raçiones de la my casa, para pagar algunas raçiones de los mys ofiçiales que se pegaron en cámara del terçio postrimero del año que pasó de mill e quatroçientos e çinquenta e tres años, dedes e paguedes luego al dicho Luys Garçía de Morales mill e quatroçientos e quarenta marauedís ques my merçed que los el reçiba de vos para los dar e pagar a Françisco de Alcalá, my repostero de camas, que los ha de aver de su raçión del dicho terçio postrimero del dicho año pasado de çinquenta e tres, e tomad su carta de pago con la qual e con esta my çédula mando a los mys contadores mayores de las mys cuentas que vos reçiban e pasen en cuenta los dichos mill e quatroçientos e quarenta marauedís, e non fagades ende al.

Fecha tres días de mayo año de çinquenta e quatro.

Yo el rey.

Por mandado del rey, Pero Ferrándes.

E en las espaldas de la dicha çédula fue escripto para el dicho Gonçalo de Alua que la vea e cunpla segund que en ella se contiene.

(Al margen, a la izquierda: el dicho despensero. Cámara. Año de iUccccliii años)

(Al margen, a la derecha: iUccccxl marauedís)

1454, mayo, 3 .

Cédula de Juan II ordenado a Gonzalo de Alba, su repostero de camas, entregar 3.000 maravedies a Luis García de Morales, despensero mayor de las raciones de la Casa del rey, para el pago en cuenta del tercio primero de la ración anual de Guyllén de Inglaterra, ministril de arpa (1.500), y de Iohanes de Alemania, tañedor de órgano de cámara del rey (1.500).

AGS, CysR, leg. 42, f. $1 \mathrm{~m}$.

El rey.

Gonçalo de Alua, mi repostero de camas, yo vos mando que de qualesquier maravedís que por mi mandado avedes resçibido o resçebiéredes para los tener en la mi cámara dedes luego a Luys Garçía de Morales, my despensero mayor de las raçiones de la my casa, tres mill maravedís que es mi merçed que los el resçiba de vos para los dar e pagar a Guyllen de Ynglaterra, mi ministril de farpa, e a Iohanes de Alemania, mi tañedor de organos de la mi cámara, a cada vno de ellos mill e quinientos marauedís que es mi merçed de los mandar dar en cuenta de los marauedís que han de aver de sus raçiones del terçio primero deste año de la fecha desta my çédula, et tomad su carta de pago con la qual e con esta my çédula mando a los mys contadores mayores de las my cuentas que vos resçiban e pasen en cuenta los dichos iiiU marauedís, e non fagades ende al.

Fecho a tres días de mayo año de çinquenta e quatro.

Yo el rey.

Por mandado del rey, Pero Ferrándes.

E en las espaldas de la dicha çédula fue escripto para el dicho Gonçalo de Alua que la vea e cunpla segund se en ella contiene.

(Al margen, a la derecha: iiiU marauedís) 
1454, mayo, 15. Tordesillas

Cédula de Juan II ordenado a Gonzalo de Alba, repostero de camas del rey, librar 11.880 anuales maravedies a Luys García de Morales, despensero mayor de las raciones de la Casa del rey, para el pago de la ración de 30 maravedies diarios que por los oficios de cronista del rey y secretario de latín correspondían a Martín de Ávila del año 1453.

AGS, CysR, leg. 42, f. $1 \mathrm{~m}$.

El rey.

Gonçalo de Alua, mi repostero de camas, yo vos mando que de qualesquier marauedís que por my mandado avedes resçebido o resçibiéredes este año de la fecha desta my merçed dedes dellos a Luys Garçía de Morales, my despensero mayor de las raçiones e tasas de la my casa, honse mill e ochoçientos e ochenta marauedís ques my merçed de le mandar para que los él de e pague a Martín de Áuila, my coronista e secretario de latýn, de su raçión que con los dichos ofiçios de mi tiene a rasón de a xxxiii marauedís cada dia e lo a de aver el año pasado de iUccccliii años, et tomad carta de pago del dicho Luys Garçía o del que los ouiere de resçebir de él, con la qual e con esta çédula mando a los mys contadores mayores de las mys cuentas que los reçiban e pasen en cuenta los dichos xiUdccclxxx marauedís, e non fagades ende al.

Fecho en Tordesillas xv días de mayo año del nasçimiento del nuestro señor Ihesu Christo de mill e quatroçientos e çinquenta e quatro años.

Yo el rey.

Por mandado del rey, relator.

E en las espaldas de la dicha çédula fue escripto para quel dicho Gonçalo de Alua que la vea e cunpla en todo e por todo segund que en ella se contiene.

(Al margen, a la derecha: xiUdccclxxx marauedís)

1454, mayo, 18.

Cédula de Juan II ordenando a Gonzalo de Alba, su repostero de camas, entregar 3.420 maravedies a Luis García de Morales, despensero mayor de las raciones de la Casa del rey, para pagar a Gellemín, francés, tenor de la Capilla Real, el tercio segundo de su ración anual.

AGS, CysR, leg. 42, f. $1 \mathrm{~m}$.

El rey.

Gonçalo de Alua, mi repostero de camas, yo vos mando que de qualesquier maravedís que por mi mandado avedes resçibido o resçibiéredes en qualquier manera para los tener en la mi cámara dedes e paguedes luego a Luys Garçía de Morales, my despensero mayor de las raçiones de la my casa, tres mill e quatroçientos e veynte maravedís que es mi merçed que los el resçiba de vos para los dar e pagar a Gellemin, françes, tenor de la my capilla, para en cuenta de su raçión que de my tiene e ha de aver del terçio segundo de este año de la fecha de esta my çédula, e dadgelos e pagadgelos luego e tomad su carta de pago de como los resçibe de vos con la qual e con esta mi çédula mando a los mjs contadores mayores de las mys cuentas que vos rresçiban e pasen en cuenta los dichos iiiUccccxx maravedís, e non fagades ende al.

Fecho dies e ocho días de mayo años de çinquenta e quatro años.

Yo el rey.

Por mandado del rey, Pero Ferrándes.

E en las espaldas de la dicha çédula fue escripto para el dicho Gonçalo de Alua que vea la dicha çédula e la cunpla segund que se en ella contiene.

(Al margen, a la derecha: iiiUccccxx marauedís) 
1454, mayo, 20. Tordesillas

Cédula de Juan II ordenado a Gonzalo de Alba, repostero de camas del rey, librar 4.320 maravedies a Luys García de Morales, despensero mayor de las raciones de la Casa del rey, para pagar a Fernando de Medina que los tenía pendientes de su ración correspondiente a 1453 por el oficio de montero de caballo del rey.

AGS, CysR, leg. 42, f. $1 \mathrm{~m}$.

El rey.

Gonçalo de Alua, mi repostero de camas, yo vos mando que de qualesquier marauedís que vos por my mandado avedes reçebido o reçibiéredes de aquí adelante en qualquier manera dedes luego a Luys Garçía de Morales, my despensero mayor de las raçiones de la my casa, quatro mill e tresientos e veynte marauedís para pagar a Fernando de Medina, my montero de cauallo, de su raçión que con el dicho ofiçio de my tiene e le fincó por pagar el año pasado de çinquenta e tres segund paresçe por vn libramiento que de los dichos marauedís fue fecho por el my mayordomo e contador al dicho Fernando de Medina en el dicho mi despensero por virtud del qual ge lo ha de reçebir en cuenta al dicho my despensero el dicho my mayordomo e contador, e tomad su carta de pago del dicho Luys Garçía con la qual e con esta my çédula mando a vos sean reçebidos en cuenta, e non fagades ende al.

De la villla de Otordesillas a veynte días de mayo año de liiii años.

Yo el rey.

Por mandado del rey, Diego Romero.

E en las espaldas de la dicha çédula fue escripto para el dicho Gonçalo de Alua que la vea e cunpla segund se en ella contiene.

(Al margen, a la derecha: iiiiUcccii marauedís)

1454, mayo, 20. Tordesillas

Cédula de Juan II ordenado a Gonzalo de Alba, repostero de camas del rey, librar 1.800 maravedies a Luys García de Morales, despensero mayor de las raciones de la Casa del rey, para el pago del último tercio de la ración correspondiente a 1453 a Andinete por el oficio de platero del rey.

AGS, CysR, leg. 42, f. $1 \mathrm{~m}$.

El rey.

Gonçalo de Alua, mi repostero de camas, yo vos mando que de qualesquier marauedís que por my mandado avedes resçebido o resçibiéredes este presente año de la fecha desta çédula dedes luego a Luys Garçía de Morales, my despensero mayor de las raçiones e tasas de la my casa, mill e ochoçientos marauedís ques my merçed de le mandar dar para que los él dé a Andinete, my platero, que los ha de aver del terçio postrimero que le fincaron por librar de su raçión que de my tiene con el dicho ofiçio el año que pasó de mill e quatroçientos e çinquenta e tres años por quanto me seruió en el dicho ofiçio residentemente el dicho año, et tomad su carta de pago con la qual e con esta çédula mando a los mys contadores mayores de las mys cuentas que vos los resçiban e pasen en cuenta, e non fagades ende al.

De la villa de Otordesillas veynte días de mayo año de çinquenta e quatro.

Yo el rey.

Por mandado del rey, Pero Ferrándes.

Registrada, Garçía Gonçáles.

E en las espaldas de la dicha çédula fue escripto para el dicho Gonçalo de Alua que la vea e cunpla.

(Al margen, a la derecha: iUdccc marauedís) 
1454, mayo, 23. Tordesillas

Cédula de Juan II ordenando a sus contadores mayores dar a Luis García de Morales, despensero mayor de las raciones de la Casa del rey, 3.600 maravedies para pagar a Nuño de Arévalo el tercio segundo de su ración que le quedaba pendiente de 1453 por el oficio de acemilero mayor del rey.

AGS, CysR, leg. 42, f. $1 \mathrm{~m}$.

El rey.

Gonçalo de Alua, my repostero de camas, yo vos mando que de qualesquier marauedís que vos yo mandé librar praa los tener en la my cámara este año de la fecha desta my çédula para las cosas que por my vos serán mandadas conplideras a my seruiçio dedes luego a Luys Garçía de Morales, my despensero mayor de las raçiones de la my casa, tres mill e seysçientos marauedís ques my merçed quel reçiba de vos para los dar e pagar a Nuño de Aréualo, my açemilero mayor, del terçio segundo de su raçión que de my tiene e le quedó por librar el año que pasó de mill e quatroçientos e çinquenta e tres años, e tomad su carta de pago de como los reçibe de vos con la qual e con esta my çédula mando a los mys contadores mayores de las mys cuentas que vos resiban en cuenta los dichos tres mill e seysçientos marauedís, e por la presente mando al dicho Luys Garçía dé e pague luego al dicho Nuño de Aréualo los dichos iiiUdc marauedís, e vos ni el dicho Luys Garçía de Morales non fagades ende al por quanto asy cunple a mi seruiçio.

De Tordesyllas a xxiii de mayo año de liiii.

Yo el rey.

Por mandado del rey, Pero Ferrándes.

Registrada, Garçía Gonçáles.

(Al margen, a la derecha: iiiUdc)

1454, mayo, 28. Tordesillas

Cédula de Juan II ordenado a Gonzalo de Alba, repostero de camas del rey, librar 3.600 maravedies a Luys García de Morales, despensero mayor de las raciones de la Casa del rey, para el pago de los dos tercios que se le adeudaban a Sancha Gómez de su ración por alfayata del rey correspondientes a 1453.

AGS, CysR, leg. 42 , f. $1 \mathrm{~m}$.

Gonçalo de Alua, my repostero de camas, yo vos mando que de qualesquier marauedís que por my mandado avedes reçebido este año de la fecha desta my çédula dedes luego a Luys Garçía de Morales, my despensero mayor de las raçiones e tasas de la my casa, tres mill e seysçientos marauedís ques my merçed de le mandar dar para que los el dé e pague a Sancha Gómes, my alfayata, de los dos terçios de su raçión que de my tiene con el dicho ofiçio e le fincaron para libar el año pasado de çinquenta e tres años, por quanto la dicha Sancha Gómes me seruió continuamente el dicho año en la my corte, et tomad su carta de cómo los reçibe de vos con la qual e con esta my çédula mando a los mys contadores mayores de las mys cuentas que vos los reçiban e pasen en cuenta, e non fagades ende al.

De la villa de Otordesillas a veynte e ocho días de mayo de çinquenta e quatro.

Yo el rey.

Por mandado del rey, Bartolomé Sánches.

E en las espaldas de la dicha çédula fue escripto para el dicho Gonçalo de Alua que la vea e cunpla segund que en ella se contiene.

(Al margen, a la derecha: iiiUdc marauedís)

1454, mayo, 31 .

Cédula de Juan II ordenado a Gonzalo de Alba, su repostero de camas, entregar 6.000 maravedies a Luis García de Morales, despensero mayor de las raciones de la Casa del rey, para el pago del tercio 
primero de la ración anual de Guyllén de Inglaterra, ministril de arpa (3.000), y de Juanes de Alemania, tañedor de órgano de cámara del rey (3.000).

AGS, CysR, leg. 42 , f. $1 \mathrm{~m}$.

El rey.

Gonçalo de Alua, mi repostero de camas, yo vos mando que de qualesquier maravedís que por mi mandado avedes resçibido o resçebides para los tener en la mi cámara dedes luego a Luys Garçía de Morales, my despensero mayor de la raçiones de la my casa, seys mill maravedís que es mi merçed que los el resçiua de vos para los dar de pagar a Guyllén de Ynglaterra, mi ministril de harpa, e a Juanes de Alemania, mi tañedor de huérganos de la mi cámara, a cada vno de ellos tres mill maravedís que es mi merçed de los mandar dar de los maravedís que han de aver de sus raçiones que de mi tiene con los dichos ofiçios del terçio primero de este año de la fecha de esta my çédula, e tomad sus cartas de pago con las quales e con esta mi çédula mando a los mis contadores de las mis cuentas que vos resçiuan e pasen en cuenta los dichos seys mill maravedís e non fagades ende al.

Fecha a treynta e vn días de mayo año de mill e quatroçientos e çinquenta e quatro años. Yo el rey.

Por mandado del rey, Pero Ferrándes.

E en las espaldas del dicho alualá estaua escripto esto que se sigue: Gonçalo de Alua, repostero de camas del rey nuestro señor, de esta otra parte contenydo ved este alualá del dicho señor rey e conplidlo en todo e por todo segund que en él se contiene e su señoría por él vos lo enbýa mandar.

1454, junio 14.

Cédula de Juan II ordenado a Gonzalo de Alba, repostero de camas del rey, librar 6.120 maravedies a Luys García de Morales, despensero mayor de las raciones de la Casa del rey, para pagar a Diego de León su ración correspondiente a 1453 por el oficio de platero del monarca.

AGS, CysR, leg. 42 , f. $1 \mathrm{~m}$.

El rey.

Gonçalo de Alua, my repostero de camas, yo vos mando que de qualesquier marauedís e doblas e florines que vos por my tenedes dedes luego a Luys Garçía de Morales, my despensero mayor de las raçiones de la my casa, de más de otros qualesquier marauedís que vos por my mandado le avedes dado, seys mill e çiento e veynte marauedís que los ha de aver para los dar e pagar a Diego de León, my platero, de su raçión quel de my tiene e le es deuido del año que pasó de mill e quatroçientos e çinquenta e tres años a rasón de a dies e siete marauedís marauedís cada dia segund paresçerá por vn libramiento que dello le será dado por el my mayordomo e contador de la despensa e raçiones de la dicha my casa, e tomad su carta de pago con la qual e con esta my çédula vos seran reçebidos en cuenta los dichos seys mill e çiento e veynte marauedís.

Fecha catorse días de junio año de çinquenta e quatro.

Yo el rey.

Por mandado del rey, Bartolomé Sánches.

Registrada, García Gonçáles.

Fue sobrescripta en las espaldas de la çédula alualá para el dicho Gonçalo de Alua que lo vea e cunpla.

(Al margen, a la derecha: viUcxx marauedís)

1454, junio, 15.

Albalá de Juan II ordenando a Ferrand González de Madrid, su guarda y vasallo, entregar a Luis García de Morales, despensero mayor de las raciones de la Casa del rey, 700.000 maravedies para el pago del primero tercio de las raciones de los oficiales de la Casa Real.

AGS, CysR, leg. 42, f. $1 \mathrm{~m}$. 
El dicho despensero.

Mostró vn alualá del dicho señor rey firmado de su nonbre fecho en esta guisa:

Yo el rey mando a vos Ferrand Gonçáles de Madrid, my guarda e vasallo, que de qualesquier marauedís que vos yo he mandado librar asy en los pedidos e catorse monedas de mys regnos como en otra qualquier manera asy este presente año de la fecha deste my alualá como el año que pasó de iUccccliii años asy para pagar a la reyna doña María de Aragon, my muy cara e muy amada hermana, çiertas contías de marauedís como para qualesquier cosas conplideras a my seruiçio, dedes e paguedes luego en dineros contados a Luys Garçía de Morales, my despensero mayor de las raçiones de la my casa, seteçientos mill marauedís que es my merçed que los él resçiba de vos para pagar el terçio primero de las raçiones de los ofiçiales de la dicha my casa deste dicho año e tomad su carta de pago con la qual e con este dicho my alualá mando a los mys contadores mayores de las mys cuentas que vos resçiban e pasen en cuenta los dichos seteçientos mill marauedís, e non fagades ende al.

Fecho xv días de junio año del nasçimiento del nuestro saluador Ihesu Christo de iUccccliiii años. Yo el rey.

Yo Pero Ferrándes de Lorca la fis escreuir por mandado de nuestro señor el rey.

Registrada.

Fue sobrescripto en las espaldas del dicho alualá para el dicho Ferrand Gonçáles que lo vea e cunpla. (Al margen, a la derecha: dccU marauedís)

1454, julio, 17. Valladolid.

Cédula de Juan II ordenando a sus contadores mayores entregar a Luis García de Morales, despensero mayor de las raciones de la Casa del rey, un total de 9.600 maravedies para pagar a maestre Alonso de Roa, cirujano del rey, un tercio de su ración que se le adeudaba de 1453 (2.400) además de la ración correspondiente a 1454 a razón de 20 maravedies diarios (7.200).

AGs, CysR, leg. 42 , f. $1 \mathrm{~m}$.

El rey.

Gonçalo de Alua, mi repostero de camas, yo vos mando que de más e allende de qualesquier marauedís que vos por my mandado avedes dado a Luys Garçía de Morales, my despensero mayor de las raçiones de la my casa, para pagar las raçiones de la dicha my casa asy el año que pasó de iUccccliii años como este año de la fecha desta çédula, dedes luego al dicho Luys Garçía de ixUdc marauedís que los ha de aver para los dar e pagar a maestre Alonso de Roa, my çerujano, de vn terçio de su raçión que de my tiene e le es deuido del dicho año pasado a rasón de xx marauedís cada dia e de su raçión que de my tyene e ha de aver este dicho año de la fecha desta çédula a rasón de los dichos xx marauedís cada día segund pareçera por vn libramiento que de los dichos marauedís le será dado por el my mayordomo e contador de la despensa e raçiones de la my casa librado del dicho Luys Garçía, e tomad su carta de pago con la qual e con esta my çédula mando que vos sean reçebidos en cuenta los dichos ixUdc marauedís de qualesquier marauedís e doblas e florines que vos por my mandado reçebistes o reçibieredes asy el dicho año pasado como este dicho año de la fecha desta çédula, e non fagades ende al.

De Valladolid a xvii días de jullio de liiii.

Yo el rey.

Por mandado del rey, Bartolomé Sánches.

Fue sobrescripto en las espaldas de la çédula para el dicho Gonçalo de Alua que lo vea e cunpla.

(Al margen, a la izquierda: los viiUcc marauedís se asentaron en la cuenta del dicho Luys Garçía de la cámara del año de liiii)

(Al margen, a la derecha: iiUcccc)

1490, marzo, 15. Sevilla.

Información aportada por Juan de León a petición del comendador Gonzalo Chacón acerca de las cosas y casos en los que entendían el mayordomo mayor y el contador mayor de la despensa y ra- 
ciones de la Casa de Juan II (1406-1454) sobre el modo de actuar de sus respectivos lugartenientes y el orden que tenía el despensero en escribir el libro del gasto de la despensa regia.

AGS, CySR, leg. 42, f. 5.

En la çibdad de Seuilla a çinco días del mes de março de mill e quatroçientos e nouenta años. Este dicho día por mandado del comendador Gonçalo Chacón, my señor, yo Diego Ramýres reçibí juramento en forma de derecho de Juan de León, vezino de la çibdad de Segouia, sobre rasón sy el dicho Juan de León sabía en qué cosas e casos entendía el mayordomo mayor de la casa del señor rey don Juan, que aya santa gloria, asymysmo si se sabía en qué cosas entendía el contador mayor de la despensa e raçiones de la casa del dicho rey et sy sabía como vsava los lugarestenyentes que tenía puestos et qué orden tenían con el despensero en el escreuir del libro del gasto de la despensa et quien lo escreuía et en qué casa e en cuyo poder quedaba el dicho libro, a lo qual e a cada vna cosa son cargo del juramento que fiso dixo e declaró lo syguiente:

Primeramente, dixo que sabe que en tienpo de dicho rey don Juan que el mayordomo mayor e su lugartenyente en su nonbre mandauan a todos los ofiçiales de la casa del dicho rey et que ellos fazían todo lo que por el mayordomo mayor o por su lugartenyente los era mandado, et que asýmysmo vido que mandaua al dspensero todas las cosas que avía de fazer para seruiçio de la casa e despensa del dicho rey, et que sabe que el dicho mayordomo mayor o su lugartenyente en su nonbre mandauan dar qualquier cosa de las que auía en la dicha despensa o se traýa a ella o todo juntamente que se fasía syn que el contador mayor de la dicha despensa ni su lugarnyente entendiesen en ello et que quando venýan a estreuir la cuenta e tomarla al despensero que non tenýan poder de testar nyn quitar ninguna cosa del gasto de la dicha despensa más de quanto quitaua el mayordomo o su lugartenyente y que todo lo otro lo pasauan y contauan como el mayordomo mandaua.

Otrosý, dixo e declaró que el contador mayor de la despensa e raçiones nin su lugartenyente no entendían en ninguna cosa de toda la casa del dicho rey, saluo en proueer a la despensa y escriuir el libro de gasto que se fazía pero que non tenýan poder para estar nin quitar de la cuenta cosa ninguna sy el mayordomo o su lugartenyente la auían pasado.

Otrosý, dixo e declaró que sabe que en el escreuir del libro del gasto de la dicha despensa que tenýan tal orden que se juntauan los lugarestenyentes de mayordomo e contador e yuan cada día a la despensa y allí escreuían todo lo que se auýa gastado y que sabe que cada vno dellos fazía su libro juntamente con el del despensero y que después de escritos que dexauan los libros en la despensa en vna arca et que después de escrito el gasto de cada día señalauan los lugarestenyentes el libro del despensero y en fyn de cada mes conçertauan todos tres libros que fazían sus feneçymiento y sacauan vna fe en linpio et en fyn de cada año fazían carta de cuenta e la lleuauan al mayordomo mayor e al contador y ellos la fyrmauan et que sabe que nunca en otra cosa entendía el dicho contador nin sy lugartenyente saluo en esto que tiene dicho.

Et asymismo dixo que sy en algund tienpo el lugartenyente de mayordomo yua fuera de la corte y estaua vn mes o dos o más tienpo que el lugartenyente entendía en la despensa en todo lo que el lugartenyente de mayordomo y esto que primeramente lo consultaua con el mayordomo mayor y que escreuía la cuenta e la pasaua y señalaua el libro y que después que venía el lugartenyente de mayordomo que señalaua aquella cuenta y la pasaua asý como la fallaua señalada del contador y esto dixo y declaró so cargo del juramento que fiso.

La qual dicha ynformaçión yo el comendador Gonçalo Chacón, mayordomo mayor de la reyna, nuestra señora, mandé aver de más y allende de lo que yo sabía y avía sydo ynformado por otras personas que dello sabían a causa que entre my lugartenyente et el lugartenyente del contador de la despensa e raçiones de la casa de la dicha reyna, nuestra señora, avía çierta diferençia sobre el escruir del libro del gasto de la despensa de su alteza et en que casa se auýa de escreuir et quién et en cuyo poder avía de estar el dicho libro.

Lo qual todo visto por my porque cunple asý al seruiçio de su alteza mando a my lugartenyente que agora es o al que fuera de aquí adelante et al lugartenyente del contador que vean esta declaraçión 
del juramento que el dicho Juan de León fizo et esta tengan e guarden e cunplan en todo segund que en ella está declarado, la qual tengan en la despensa de su alteza. años.

Fecho en la çibdad de Seuilla a quinse días del mes de março de myll e quatroçientos e noventa Gonçalo Chacón (rúbrica). 